ANTONIO HENRIQUE MONTERO DEL RIO

A cisão subjetiva na lírica portuguesa: século XVI e século XX

Dissertação apresentada à Faculdade de Filosofia, Letras e Ciências Humanas da Universidade de São Paulo para obtenção do título de Mestre em Letras.

Área de Concentração: Literatura Portuguesa Orientador: Profa. Dra. Marcia Arruda Franco 


\section{FOLHA DE APROVAÇÃO}

Antonio Henrique Montero del Rio

A cisão subjetiva na lírica portuguesa: século XVI e século XX

Dissertação apresentada à Faculdade de Filosofia, Letras e Ciências Humanas da Universidade de São Paulo para obtenção do título de Mestre.

Área de Concentração: Literatura Portuguesa

Aprovado em:

Banca Examinadora

Prof. Dr.

Instituição: Assinatura:

Prof. Dr.

Instituição: Assinatura:

Prof. Dr.

Instituição: Assinatura:

Prof. Dr.

Instituição: Assinatura:

Prof. Dr.

Instituição: Assinatura: 


\section{DEDICATÓRIA}

A todos os meus colegas e amigos professores. 


\section{AGRADECIMENTOS}

À Profa. Dra. Marcia Arruda Franco, orientadora deste trabalho, que, nos anos de convivência, muito me ensinou, contribuindo para meu crescimento intelectual.

À Faculdade de Filosofia, Letras e Ciências Humanas, pela oportunidade de realização do curso de mestrado.

Aos Senhores membros da banca examinadora, pela honra que me é concedida ao ser examinado por tão ilustres professores.

Aos funcionários da Biblioteca Florestan Fernandes, pelo atendimento sempre cordial.

Às Professoras Annie Gisele Fernandes e Sandra Nitrini, que ministraram, a mim e a meus colegas de pós-graduação, maravilhosas disciplinas.

Ao amigo e colega Prof. Paulo Hideyuki Shimoda Ishii, por sua inestimável ajuda na solução de problemas relacionados à informática.

A Thaís Barbosa de Paola, que carinhosamente franqueou a sua biblioteca para consultas e dúvidas. 
"Os antagonismos não resolvidos da realidade retornam às obras de arte como os problemas imanentes da sua forma."

Theodor W. Adorno, Teoria estética 


\section{RESUMO}

DEL RIO, A. H. M. A cisão subjetiva na lírica portuguesa: século XVI e século XX. 2009. Dissertação (Mestrado) - Faculdade de Filosofia, Letras e Ciências Humanas, Universidade de São Paulo, São Paulo, 2009.

A cisão do eu é um tema literário. Há mesmo uma literatura do eu cindido. Ele aparece em todas as literaturas do mundo e á parte do tema mais amplo do duplo, que também aparece em toda literatura e em todo gênero literário. Mas o eu cindido, ou a cisão subjetiva do eu, é um assunto peculiar à Lírica, por causa do seu caráter subjetivo, ao contrário do duplo em outros gêneros literários, como o Drama e a Narrativa, que apresentam um caráter objetivo. Este trabalho tem como objetivo o estudo da cisão subjetiva na lírica portuguesa para demonstrar que a cisão do eu poético na lírica portuguesa é um tema presente na literatura portuguesa do século XVI e do século XX. Nosso método de trabalho incluiu uma pesquisa para fixar um corpus poético dos dois séculos, uma comparação entre eles, e a leitura de obras críticas e filosóficas relacionadas a este tema para tentar esboçar uma conclusão. Nosso corpus poético inclui poemas de Jorge Manrique, Francisco de Sá de Miranda, Bernardim Ribeiro, Luís Vaz de Camões (no século XVI); e de Mário de Sá-Carneiro, Fernando Pessoa, Alexandre O’Neill, Maria Teresa Horta (no século XX). Nossas obras filosóficas consultadas mais importantes foram Discurso sobre a dignidade do homem, de Giovanni Pico Della Mirandola; Elogio da loucura, de Erasmo de Roterdam; Manuscritos econômico-filosóficos, de Karl Marx; e $O$ ser e o nada, de Jean-Paul Sartre. Concluímos que a lírica portuguesa do século XX retoma o tema da cisão subjetiva do eu em vários poemas escritos por muitos dos mais importantes poetas do século, mas com uma concepção moderna de Literatura.

Palavras-chave: Literatura portuguesa. Poesia lírica. Duplo. Eu cindido. Cisão subjetiva do eu. Inimigo de si. 


\begin{abstract}
DEL RIO, A. H. M. The scission of the self in Portuguese lyric poetry: fifteenth century and twentieth centure. 2009. Thesis (Mestrado) - Faculdade de Filosofia, Letras e Ciências Humanas, Universidade de São Paulo, São Paulo, 2009.

The divided self is literary theme. There is really a literature of the second self. It appears in all literatures around the world, and it is a part of the larger theme of the double, which also appears in all literature and in all literary genus. But the divided self, or the subjective scission of the self, is a peculiar topic of the lyric poetry, because of its subjective character, on the contrary of the double in others literary genus, as the drama or the narrative, which presents an objective character. This work means to make a study on the divided self in Portuguese lyric poetry, to demonstrate that this theme, which appears in sixteenth century's Portuguese literature, also appears in twentieth century's Portuguese literature. Our method of work included a research to set a corpus of poems of the both centuries, a confrontation between them, and the reading of philosophical and critical works concerning on this theme, to try to draw a conclusion. Our poetic corpus includes poems from Jorge Manrique, Francisco de Sá de Miranda, Bernardim Ribeiro, Luís Vaz de Camões (in the sixteenth century); and from Mário de Sá-Carneiro, Fernando Pessoa, Alexandre O'Neill, Maria Teresa Horta (in the twentieth century). And our most important philosophical works were Giovanni Pico Della Mirandola's Oratio de hominis Dignitate, Erasmo de Roterdam's Elogio da Loucura, Karl Marx's Manuscritos econômicofilosóficos, and Jean-Paul Sartre's $O$ ser $e$ o nada. We concluded that the twentieth Portuguese lyric poetry retakes the theme of the subjective scission of the self in several poems written by many of the most important poets of the century, but as a modern conception of literature.
\end{abstract}

Keywords: Portuguese Literature. Lyric poetry. Double. Diveded self. Subjective scission of the self. Self enemy. 


\section{SUMÁRIO}

1 Esclarecimentos gerais sobre a delimitação do tema e objetivos da pesquisa

2 Por que a Lírica

3 Do amor cortês à cisão subjetiva

4 Pico Della Mirandola, Sá de Miranda, Ribeiro, Camões e o inimigo de si

5 A recepção da cisão subjetiva na lírica portuguesa pós-simbolista

6 Tentativa de conclusão

103

Referências

Anexo 


\section{Esclarecimentos gerais sobre a delimitação do tema e objetivos da pesquisa}

O objetivo deste trabalho é estudar, diacronicamente, o tema da cisão subjetiva do eu poético na lírica portuguesa, para demonstrar a sua presença na produção poética quinhentista e novecentista, em Portugal. O desdobramento do eu lírico em dois entes paralelos ou antagônicos inscreve-se no assunto mais amplo do duplo literário, cuja denominação primordial e básica é a de alter ego (outro eu). Poder-se-ia mesmo dizer que este é gênero e aquele, espécie. Este outro eu é obtido pelo texto literário de várias formas, e a cisão do eu lírico é uma delas, justamente a que ora é objeto de estudo. O duplo é figura literária encontrável nos três gêneros: Lírico, Épico e Dramático; mas a cisão é própria da Lírica, como adiante se verá.

A presença do eu lírico fragmentado na poesia lusa pode ser observado ao longo de toda a história da literatura portuguesa, entre o século XVI e a contemporaneidade. Entretanto, nesta dissertação, a análise estará concentrada em dois períodos específicos desse grande lapso temporal de cinco séculos: o Quinhentismo ${ }^{1}$; e o Novecentismo ${ }^{2}$. Esta delimitação se deve ao fato de que o projeto de pesquisa desenvolvido durante o mestrado propõe, em linhas gerais, um cotejo entre o passado e o presente; e, mais especificamente, a análise de releituras dos temas de autores quinhentistas por autores novecentistas. O projeto é fruto da adesão à linha de pesquisa há bastante tempo realizada pela orientadora deste trabalho, Marcia Arruda Franco.

\footnotetext{
${ }^{1}$ Adotou-se, aqui, a demarcação cronológica do Quinhentismo literário português proposta por José Augusto Cardoso Bernardes, no prefácio escrito para o livro Sá de Miranda poeta do Século de Ouro, de Marcia Arruda Franco, por nos ter parecido a mais adequada. Segundo esta demarcação, o Quinhentismo literário português tem início em 1495, com a subida ao trono de D. Manuel, e se encerra em 1580, com a união dinástica das Coroas de Portugal e Espanha e com a presumível morte de Camões.

${ }^{2}$ A definição de Novecentismo é mais simples, entendo-se como a produção poética do séc. XX. Veja-se o corpus poético que segue em anexo.
} 
A recepção no século XX, especialmente por Fernando Pessoa e Mário de Sá-Carneiro, do tema da cisão subjetiva na lírica portuguesa do século XVI (ciclo temático do “inimigo de si”) será, portanto, nosso objeto de análise. Essa temática é recepcionada de maneiras diversas, de acordo com o autor que a recepciona. O plano de exposição dos resultados da investigação obedecerá ao critério de organizar o trabalho em um capítulo que pretende justificar o enfoque da cisão do eu na Lírica; em outro que demonstra a relação da cisão do eu com o amor cortês medieval; e em duas outras grandes seções: uma que trata dos autores quinhentistas do corpus (Jorge Manrique ${ }^{3}$, Francisco de Sá de Miranda, Bernardim Ribeiro e Luís de Camões) e outra que trata dos autores novecentistas do corpus (Fernando Pessoa, Mário de Sá-Carneiro, Maria Teresa Horta e Alexandre O’Neill). Nesta, tentar-se-á também relacionar o problema com a obra de Vincent Van Gogh, notadamente seus auto-retratos, por entender-se que, nas artes plásticas, sua obra representa a cisão subjetiva de maneira admirável.

A instrumentação teórica que fundamentará a análise é eclética. Conta com um instrumental técnico oriundo da Teoria Literária e da Filosofia. Com isso, busca-se realizar um trabalho de crítica literária que se enriquece no contato com o campo do saber que é, ao lado do estudo da Literatura, soberano entre as ciências humanas. Além disso, o eu poético é uma das vertentes do Ser, figura cara a todo estudo filosófico.

As obras que constituem o corpus poético de análise oferecem sempre uma pista textual da cisão íntima do eu lírico. Não obstante, a cisão do eu poético também

\footnotetext{
${ }^{3}$ Jorge Manrique é espanhol e viveu no século XV. Mas sua presença no corpus se justifica porque foi o iniciador do ciclo temático do "inimigo de si" na poesia lírica, e influenciou de forma decisiva os poetas portugueses que desenvolveram o tema no século XVI e que foram recepcionados no século XX.
} 
aparece em ocorrências extremamente sutis. Entretanto, tais ocorrências estão sujeitas a uma interpretação que tange o imponderável, o que escapa à metodologia adotada no presente estudo, o qual está filiado ao método de pesquisa tradicionalmente consagrado nesta instituição: ater-se ao que efetivamente diz o texto literário ${ }^{4}$. Segue em anexo uma antologia de poemas, da qual foram retirados todos os poemas que ilustraram as análises deste trabalho, constituindo assim o nosso corpus poético.

\footnotetext{
${ }^{4}$ Como expoente que pode ser identificado nessa linhagem de pesquisa tem-se o Professor Antonio Candido e o seu já clássico Estudo analítico do poema.
} 


\section{Por que a lírica}

A experiência do duplo na Lírica é essencialmente subjetiva. A cisão do eu lírico não é uma cisão objetiva, como a que ocorre com o duplo no Gênero Dramático, ou seja, em duas pessoas. O Gênero Dramático se beneficia de uma grande facilidade para representar o duplo, por meio de um segundo personagem em cena. Mas o fenômeno literário do duplo enquanto experiência da subjetividade e decorrente de uma cisão íntima é assunto privativo da Lírica.

O Gênero Dramático, com suas múltiplas personagens em cena, vale-se do duplo como argumento central de comédias nas quais a trama se desenrola em torno de uma usurpação de identidade. O Quinhentismo literário fornece em profusão exemplos de comédias onde a confusão de identidades via existência de um duplo é o tema fundamental da peça. São basicamente releituras de Plauto e sua Menaechmi de 206 a.C. ${ }^{5}$, na qual dois gêmeos idênticos que nunca haviam se visto se encontram casualmente e, a partir daí, uma série de situações constrangedoras se sucedem até a cena final de reconhecimento por testemunhas.

Na Itália, a comédia Il Calandro, de 1513, de Bernardo Dovizi ${ }^{6}$, mais conhecido como Cardeal Bibbiena por causa do nome da localidade toscana onde exerceu o seu múnus eclesiástico, apresenta dois gêmeos, porém menino e menina, que viviam separados e se encontram em Roma. Apesar de não serem idênticos, pois são de sexos diferentes, a menina, usando roupas masculinas, era facilmente confundida com o irmão,

\footnotetext{
${ }^{5}$ Titus Maccius Plautus. Menaechmi. New York: Cambridge University Press, 1993.

${ }^{6}$ Bernardo Dovizi. La Calandria. Torino: G. Einaudi, 1967.
} 
sendo uma espécie de duplo. A peça apócrifa Gli Ingannatti, de $1531^{7}$, inspira-se no enredo da anterior e também põe em cena dois gêmeos que vivem separados: Fabrizio e Lelia. Em 1556, Lope de Rueda escreve peça semelhante e com o mesmo título, Los engañados, em Castelhano $^{8}$. Apesar de a história ser basicamente a mesma, no século XVI não havia a noção de plágio que há hoje. Pouco depois, em 1562, Niccolo Secchi ${ }^{9}$ retoma o argumento na sua peça Gli inganni, porém com alguns elementos trágicos, já que o casal de gêmeos é vendido como escravo e a menina, em trajes masculinos, desperta o amor em outra mulher. A confusão se desfaz ao final, com o aparecimento do irmão.

Não obstante o teor angustiante da separação, que transparece claramente nessas obras, William Shakespeare fornece um contraponto extremamente cômico ao tema na sua peça The Comedy of errors, de $1593^{10}$. De certa forma, e jocosamente, Shakespeare duplica o duplo, colocando em cena um par de gêmeos criados comandados por um par de gêmeos patrões. Conseqüentemente, as confusões são igualmente duplicadas até a cena final de reconhecimento.

O teatro espanhol do Século de Ouro representa o duplo por meio da figura do sósia, e a confusão de identidade ocorre em virtude de uma usurpação. Essa usurpação, em princípio ilegítima, poderá legitimar-se a posteriori conforme o caso (de fato ou de direito); e poderá ser benéfica ou maléfica. É muito comum, nas peças dos

\footnotetext{
${ }^{7}$ Biblioteca dell'eloquenza italiana di monsignore Giusto Fontanini arcivescovo d'Ancira, con le annotazione dell signor Apostolo Zeno istorico e poeta cesareo, cittadino veneziano. Accresciuta di nuove aggiunte. Tomo Primo. Per li Fratelli Gozzi. Con permissione. A spese di Luigi Mussi. Parma: Biblioteca Fagnani, MDCCCII. ${ }^{8}$ Lope de Rueda. "Los engañados". In: Teatro completo. Barcelona: Editorial Bruguera, 1979.

${ }^{9}$ Biblioteca dell'eloquenza italiana di monsignore Giusto Fontanini arcivescovo d'Ancira, con le annotazione dell signor Apostolo Zeno istorico e poeta cesareo, cittadino veneziano. Accresciuta di nuove aggiunte. Tomo Primo. Per li Fratelli Gozzi. Con permissione. A spese di Luigi Mussi. Parma: Biblioteca Fagnani, MDCCCII. ${ }^{10}$ William Shakespeare. The Comedy of erros. London: Methuen \& Co. Ltd., 1962.
} 
autores deste período, que a semelhança entre o rei ou um nobre e um simples plebeu ou mesmo um trabalhador braçal sirva a fins políticos, como a tomada do poder estatal.

O Licenciado Juan de Grajales parece ter sido um dos pioneiros no tema com sua peça El rey por semejanza, de $1600^{11}$. Nela, um rei excessivamente autoritário é morto pelo amante da rainha, que põe no lugar do monarca assassinado um sósia desconhecido. Surpreendentemente, este se torna um grande governante. Neste caso, a usurpação, além de benéfica, legitimou-se de fato, já que, do ponto de vista prático, o executante do poder real, mesmo sendo um impostor, passou a exercê-lo para o bem comum.

Já no auge da produção literária do Século de Ouro da literatura espanhola, o monge mercedário Gabriel Telles, conhecido como Tirso de Molina, pseudônimo que o imortalizou, vale-se deste argumento na sua peça La Ventura con el nombre, de $1630^{12}$. No título da obra, Telles emprega a palavra "Ventura" com duplo sentido, pois se reporta ao nome da personagem principal: um homem chamado Ventura (por isso a inicial maiúscula) que, por sua semelhança com o rei morto, o substitui na chefia do Estado. Ocorre que, na verdade, Ventura é meio irmão do falecido monarca. Por fim, ele é aclamado como legítimo rei, tanto pela sua filiação quanto pelos seus êxitos na guerra e na administração pública. Na peça de Tirso de Molina, a solução da trama se reveste de uma legitimidade prática que corrobora a legitimidade jurídica: a aclamação de

\footnotetext{
11 Dramáticos contemporaneos a Lope de Vega. Colección Biblioteca de Autores Españoles, desde la Formación del Lenguaje hasta nuestros dias. Tomo Segundo. Madrid: M. Rivadeneyra - impresor - editor, 1858.

${ }^{12}$ Tirso de Molina. "La Ventura con el nombre". In: Obras dramáticas completas Tomo IV. Madrid: Aguilar, 1989.
} 
Ventura como rei dá-se em virtude dos seus méritos pessoais, mas estaria em perfeita conformidade legal se esses méritos não existissem, pois seria amparada no jus sanguinis.

Lope de Vega, autor clássico do teatro espanhol do Século de Ouro, na sua comédia El palacio confuso, de $1630^{13}$, apresenta uma rainha casada em segundas núpcias com um rei que toma medidas governamentais extremamente populares, mas hostis à nobreza. Para neutralizar as ações do rei, os nobres e a rainha se valem de um sósia que determina medidas diametralmente contrárias às do verdadeiro monarca, quando este está dormindo. A revelação final da peça é que o rei e o sósia são irmãos gêmeos, filhos do monarca anterior, que havia morrido na guerra. A solução dada por Lope de Vega à confusão provocada pela existência do duplo parece equilibrar interesses antagônicos: os da nobreza e os da plebe. Os dois gêmeos têm o mesmo direito à Coroa, já que não é possível saber qual deles saiu primeiro do ventre materno. No entanto, tal solução conduz a trama a um impasse.

A obra dramática de Sá de Miranda inclui a comédia Os Vilhalpandos ${ }^{14}$, que relê a questão do duplo nos mesmos termos que as obras anteriores, ou seja, faz parte da posteridade literária suscitada por Plauto e sua Menaechmi. Camões, na auto chamado Dos Enfatriões ${ }^{15}$, retoma o tema do duplo tal como é tratado na peça Amphitruo, de Plauto (a peça de Camões tem mesmo uma personagem com o nome de Sósia, como na de Plauto), tragicomédia que junta o maravilhoso ao cotidiano. Note-se que, conforme salienta Marcia Arruda Franco (2005, p. 42 e 43), o auto difere da comédia por admitir um enredo

\footnotetext{
${ }^{13}$ Felix Lope de Vega y Carpio. El palacio confuso. New York: Ediciones del Instituto de las Españas en los Estados Unidos, 1939.

${ }^{14}$ Francisco de Sá de Miranda. "Os Vilhalpandos". In: Obras completas vol. 2. Lisboa: Livraria Sá da Costa Editora, 1976.

${ }^{15}$ Luís de Camões. "Auto chamado dos Enfatriões”. In: Teatro completo. Prefácio, notas e fixação do texto por Vanda Anastácio. Porto: Edições Caixotim, 2005.
} 
mais fantasioso que esta. Ela observa, pela leitura do prólogo de Os estrangeiros, que a comédia mirandina é um gênero verossímil e que traz um discurso em prosa, pois se destina a veicular uma crítica às instituições vigentes. A peça de Camões apresenta duas formas de esvaziamento de identidade (ANASTÁCIO, 1991): o “despojamento de si próprio", quanto a Sósia, pois Mercúrio pretende apropriar-se definitivamente da sua identidade; e a perda de um determinante de identidade externo a si próprio (a mulher amada), quanto a Anfitrião, pois a sua honra de marido o caracteriza enquanto indivíduo de um determinado lugar social. No caso do criado Sósia, o engano engendra a angústia de ver anulada a própria identidade; e no caso de Anfitrião, a fúria por haver sido desonrado.

Como se vê, no Gênero Dramático, o duplo se manifesta por meio de uma divisão objetiva. Não há fragmentação do eu, já que a duplicação produz dois entes distintos e inconfundíveis. Ainda que exista confusão de identidades, ela é temporária e não implica conflito interior. Sempre, ao final da peça, a confusão é desfeita em uma cena de reconhecimento geral, onde as personagens periféricas da trama inteiram-se do equívoco, pois é justamente nisto que consiste a cisão. Mas as duas personagens principais, supostamente cindidas, em nenhum momento duvidaram do próprio eu ou estiveram em conflito consigo mesmas. O Sósia de Camões duvida de si mesmo porque vê diante de si uma figura fisicamente igual a sua. A dúvida de Sósia consiste em saber se a sua identidade foi usurpada ou se ele esteve sempre enganado quanto a quem era. Além disso, não há conflito íntimo em Sósia.

Por outro lado, na Lírica, um conflito íntimo engendra o duplo como uma projeção da desordem interior. Quando migra do âmbito dramático para o âmbito lírico, o fenômeno literário do duplo evolui de uma representação do fisicamente idêntico, 
de maneira a preservar a unidade do Ser, para uma representação da quebra ou cisão dessa unidade. No Drama, o duplo é fruto da semelhança direta entre dois seres: o distúrbio tem sua fonte num elemento externo e, reconhecido este, o problema se resolve; na Lírica, o distúrbio engendra o duplo, que nasce desse distúrbio dentro do eu: o elemento desagregador é interno. No Gênero Dramático, o duplo gera a desordem; no Gênero Lírico, a desordem gera o duplo.

Com as explicações supra a respeito das diferentes manifestações do fenômeno literário do duplo, conforme apareçam no Gênero Dramático ou no Gênero Lírico, e a abundante exemplificação, torna-se desnecessária uma explanação detida para o Gênero Épico, já que se pode facilmente inferir a impossibilidade da cisão íntima do eu tal como ocorre na Lírica - em uma obra narrativa. No Gênero Lírico, objetividade e subjetividade interpenetram-se (BACHELARD, 1991). Na Épica, não. O fidalgo Alonso Quijano e Don Quijote de la Mancha são duplos, sendo este ainda um duplo literário, pois é uma construção imaginária daquele, com base em um modelo literário extraído das novelas de cavalaria. Dr. Henry Jekyll e Mr. Edward Hyde são duplos - talvez os mais conhecidos da literatura universal. No entanto, entre essas personagens e o leitor, interpõe-se a figura do narrador, o que impede a fusão entre sujeito e objeto. Conforme ensina Walter Benjamin (1987, p. 198) na tese 2 de "O narrador”, a fonte de toda narrativa é uma experiência que passa de pessoa a pessoa. Adiante, na tese 5 (BENJAMIN, 1987, p. 201), explica que o narrador recolhe na experiência (própria ou alheia) o que conta, para incorporar o narrado à experiência do leitor. Na tese 9, conclui de forma categórica: "Assim se imprime na narrativa a marca do narrador, como a mão do oleiro na argila do vaso" (BENJAMIN, 1987, p. 205). Enquanto na Lírica as esferas anímica e objetiva se reúnem no eu lírico, no 
Drama elas interagem por meio do encontro. E na Épica, o eu do narrador se depara com algo que capta e expressa.

Ressalve-se, no entanto, a possibilidade de interpenetração entre os gêneros literários (KAYSER, 1967). Estes podem ser classificados pela forma exterior de apresentação das obras. Neste sentido, qualquer peça de teatro - seja de Plauto, Shakespeare ou Nelson Rodrigues - pertence ao Gênero Dramático; qualquer narração, ao Gênero Épico; e, por exemplo, toda a obra poética de Vinícius de Moraes, ao Gênero Lírico. Os gêneros literários podem ainda, num sentido mais interior, de acordo com o conteúdo e a construção do discurso, ser determinados pelas "formas naturais da poesia ou atitudes básicas” (KAYSER, 1967, p. 223), que são: "atitudes e formas do lírico"; "atitudes e formas do épico"; e "atitudes e formas do drama". Logo, do ponto de vista interno das obras literárias, é possível identificar três vertentes, que correspondem aos três gêneros identificáveis pela sua apresentação externa.

Isso significa que, sem prejuízo da qualidade, uma obra dramática pode conter elementos épicos e líricos; uma obra épica pode estar impregnada de lirismo e dramaticidade; e uma obra lírica pode apresentar traços épicos e dramáticos. Anatol Rosenfeld (2000) afirma categoricamente que tipos puros e ideais de obras não existem na literatura real, o que se verifica facilmente pela análise das "variações empíricas e a influência de tendências históricas nas obras individuais que nunca são inteiramente puras" (ROSENFELD, 2000, p. 21). Não há como negar, entretanto, que a concepção de Kayser a respeito dos gêneros literários de certa forma os retira da sua historicidade. 
O centro literário do Gênero Dramático é a ação, é através dela que se apreende o significado da obra dramática. O Gênero Lírico tem como veículo de comunicabilidade o texto, ou seja, a própria poesia. Esta conta com as suas próprias sugestões para transmitir seu conteúdo. A Épica conta, o Drama mostra e a Lírica sugere. Na Lírica, o discurso é o símbolo da idéia. Por isso o texto lírico não admite paráfrase: outro discurso seria inevitavelmente arbitrário e não corresponderia à idéia original. 


\section{Do amor cortês à cisão subjetiva}

A Idade Média introduz o amor como grande tema da literatura ocidental. Este se apresenta em duas vertentes: a erótica latina e o amor cortês. O amor eminentemente erótico é caracterizado pelo seu aspecto físico, sensual e vivenciado pela experiência dos sentidos. Sintetiza-se na expressão latina carpe diem. A partir destas características, os latinos desenvolveram uma retórica própria para este tipo de discurso. Os sintomas do amor passaram a ser o desejo e a satisfação sexual. Já na concepção do amor cortês, o amor é entendido como uma infinita cadeia de amores não correspondidos, na qual a amada está sempre acima do amante e é vista por este como criatura perfeita. $\mathrm{O}$ poema seguinte, de Sá de Miranda ( $\mathrm{n}^{\circ} 26$ da antologia mirandina do anexo), apresenta um sujeito em situação de profunda inferioridade em relação à mulher amada, o que ilustra o amor cortês. $\mathrm{O}$ amante pede perdão à amada pelo amor que sente, já que esta retribui os serviços prestados por aquele com uma imposição de coima.

Até quando me tereis

nesta dor que por vós quis?

Os serviços que vos fiz

quando mos perdoareis?

Não ser vosso não é em mim:

isto quereis-mo acoimar?

Que perdão posso esperar

pera a alma, vossa sem fim?

Se me tanto mal fazeis

por serviços que vos fiz,

o bem que vos quero e quis

quando mo perdoareis? ${ }^{16}$

O amor medieval, ou cortês, é imaginado como um paradoxo de alegria e dor ao mesmo tempo (BLOCH, 1999). O sujeito poético não é capaz de alcançar o seu

\footnotetext{
${ }^{16}$ Francisco de Sá de Miranda. Obras completas Volume I. $4^{\text {a }}$ edição, revista. Texto fixado, notas e prefácio de Rodrigues Lapa. Lisboa: Livraria Sá da Costa Editora, 1976. pp. 56 e 57.
} 
desejo, um dilema que reflete a rejeição da dama em desejar o que ela poderia conseguir. O sine qua non do desejo é que a mulher desejada seja perfeita. Entretanto, a condição da sua perfeição é que ela seja auto-suficiente, isto é, completa em si mesma independentemente de fatores externos à sua pessoa e, sendo desejada, ela própria não deseje. A perfeição da mulher objeto do amor impede que ela deseje. Para ser amada, conforme a dialética da relação cortês, a mulher necessariamente tem que ser inacessível, insensível e imaculada: uma virgem. O poema seguinte, de Bernardim Ribeiro, é um típico poema de amor por uma mulher inatingível ( $\mathrm{n}^{\mathrm{o}} 5$ da antologia bernardiniana no anexo):

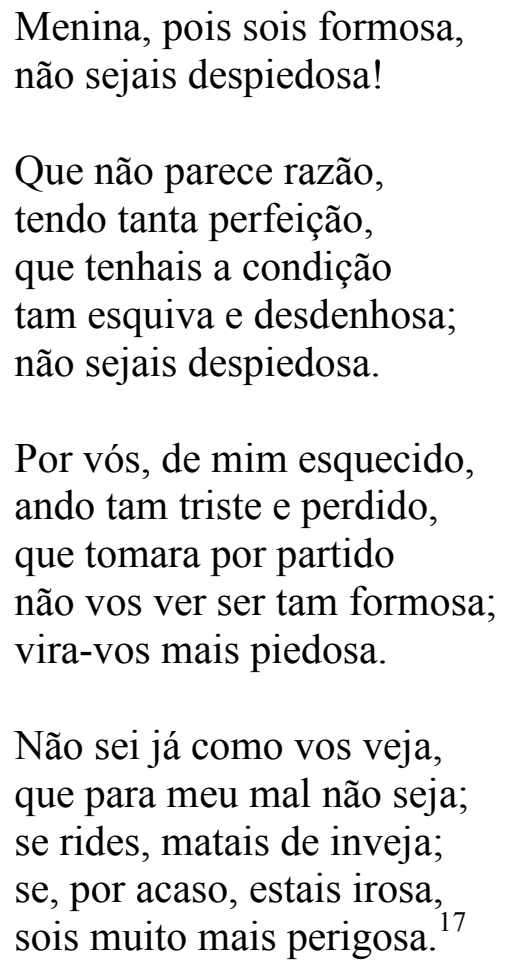

O sujeito poético pede piedade à amada, apelando para o seu bom senso: que seja ela coerente consigo mesma, pois sendo perfeita não se admite que tenha o vício moral da impiedade. À primeira vista, é uma argumentação engenhosa. No entanto, se ela

\footnotetext{
${ }^{17}$ Obras poéticas de Bernardim Ribeiro - edição revista e prefaciada por Delfim Guimarães. Lisboa: Livraria Editora Guimarães \& Ca, 1930. p. 199.
} 
fosse piedosa e cedesse, deixaria de ser inacessível e, portanto, perfeita na total ausência de máculas. Não há escapatória para este paradoxo.

Esta é a visão de Howard Bloch (1999), à qual nos filiamos em virtude da opção metodológica para o presente trabalho, já mencionada no exórdio deste, de ater-se estritamente ao discurso literário em questão. Entretanto, isto não significa que ela seja pacífica. Georges Duby (1989), analisando a produção literária do período por uma perspectiva histórica - ou seja, levando em conta costumes em voga e cotejando as obras com documentos, tais como registros públicos e atas notariais -, propõe que o amor cortês era um valor difundido na sociedade aristocrática da época, e que era utilizado para fins políticos.

Duby pondera que os casamentos entre membros da elite medieval obedeciam a interesses de ordem econômica, como evitar a divisão de fortunas e, se possível, ampliá-las pela fusão de duas famílias ricas por meio de um casamento arranjado. Em oposição a esse casamento por mero interesse, os doutores da Igreja e as autoridades eclesiásticas se dedicavam a propugnar o amor livre das injunções familiares e o casamento contraído mediante consensus. O autor associa essa concepção de casamento ao amor cortês para declarar que "o amor que permite escolha da lírica cortês pretende bem, ele também, unir em princípio dois seres e não duas parentelas, duas heranças, duas redes de interesses" (DUBY, 1989, p. 26). Ocorre que a necessidade de promover a manutenção de fortunas e das relações feudais de vassalagem fez com que a lírica do amor cortês fosse, de certa forma, cooptada por essa ideologia dominante ${ }^{18}$. Assim como muitos jovens fidalgos

\footnotetext{
${ }^{18}$ Ideologia é um conceito marxista que designa uma distorsão de pensamento, que nasce dos antagonismos sociais, associada a uma inversão da realidade, que oculta tais antagonismos. Ao ocultar os antagonismos de
} 
eram obrigados a contrair núpcias para agregar fortunas, muitos outros tinham necessariamente que manter-se celibatários para não desagregá-las, ou simplesmente não encontravam nenhuma família disposta a ceder-lhes uma noiva por serem desprovidos de bens. Ao situar o amor cortês fora do âmbito matrimonial, garantia-se uma considerável segurança institucional para o casamento. Logo, posto nesses termos, o amor cortês exercia uma função pedagógica na sociedade (DUBY, 1989, pp. 37-39). Além disso, o amor cortês também se coadunava com as normas de vassalagem (DUBY, 1989, pp. 59-65), pois haveria uma semelhança entre a submissão do eu poético à amada e a submissão do vassalo ao suserano. "O amor cortês ensinava a servir e servir era o dever do bom vassalo" (DUBY, 1989, p. 64). E, segundo este autor, a lírica de amor cortês seria uma forma de angariar a simpatia de grandes senhores através das suas esposas, o que não representaria risco algum à fidelidade conjugal, já que amor cortês e casamento eram incompatíveis e a dama desejada é sempre inatingível. Nas palavras do autor: "servindo à sua esposa, era (estou persuadido) o amor do príncipe que os jovens queriam ganhar, esforçando-se, dobrando-se, curvando-se" (DUBY, 1989, p. 65).

Dados os devidos créditos ao entendimento divergente, cumpre retomar a linha de raciocínio adotada. Não sem antes frisar que o próprio proponente de tal corrente diversa não se mostra seguro quanto ao que afirma e reconhece a relativa inconsistência da

classe, a ideologia favorece os interesses das classes dominantes. Veja-se: IDEOLOGIA. In: Dicionário do pensamento marxista. Editado por Tom Bottomore. Rio de Janeiro: Jorge Zahar Editor, 1993, pp. 183-187. "Com efeito, enquanto os homens, por força de seu limitado modo material de atividade, são incapazes de resolver essas contradições na prática, tendem a projetá-las nas formas ideológicas de consciência, isto é, em soluções puramente espirituais ou discursivas que ocultam efetivamente, ou disfarçam, a existência e o caráter dessas contradições. Ocultando-as, a distorção ideológica contribui para a sua reprodução e, portanto, serve aos interesses da classe dominante. Portanto, a ideologia surge como um conceito negativo e restrito. É negativo porque compreende uma distorção, uma representação errônea das contradições. É restrito porque não abrange todos os tipos de erros e distorções. A relação entre as idéias ideológicas e não-ideológicas não pode ser interpretada como a relação geral entre erro e verdade. As distorções ideológicas não podem ser superadas pela crítica, só podem desaparecer quando as contradições que lhes deram origem forem resolvidas na prática” p. 184 
sua argumentação, conforme se depreende da forma com que conclui seu pensamento quanto ao tema: "Eis uma das hipóteses de pesquisa, incerta, hesitante, que empreendo" (DUBY, 1989, p. 65).

O amor na lírica medieval é o grande motivo de sofrimento por não ser correspondido. Mas, para o sofrimento derivado desse amor, o poeta encontra alívio na ascese: o ato de amar é espiritualizante e conduz à perfeição. Na perspectiva quinhentista, o amor cortês é acrescido de elementos cristãos: fraternidade, contemplação, abandono de si, admiração pelo superior. E a conclusão é que o sofrimento promove o crescimento. Logo, a recompensa pelo sofrimento do amor é a purificação e o sujeito passa a amar mais o próprio sentimento do amor que o seu objeto. Veja-se a volta de Sá de Miranda ao vilancete de António de Azevedo, $\mathrm{n}^{\mathrm{o}} 22$ da antologia mirandina do anexo:

Polo bem, mal me quisestes!
E eu nunca tenha prazer
se vos mal posso querer!
For' ela razão igual!
Mas vede as leis que amor tem:
que em vez de vos querer mal,
assi vos quero mor bem!
E passo tanto inda além
do que este mal sói fazer,
que me venho a aborrecer.

$\mathrm{O}$ amante ama tanto a mulher, que retribui o mal com o bem. A influência dessa concepção estóico-cristã de amor faz com que a conjunção carnal seja eliminada como forma possível de realização amorosa. Mas não impede a existência deste "tormento de amar", que é ilustrado no poema "Vosso bem-querer, Senhora" (nº 8 da antologia camoniana do anexo). $\mathrm{O}$ amor, que em princípio é uma coisa boa, tendo esse tipo

\footnotetext{
${ }^{19}$ Francisco de Sá de Miranda. op. cit. pp. 44 e 45.
} 
de mulher por objeto, não é mais que tormento. Não amá-la seria melhor. O poema "Senhora, pois não deixais" (n 2 da antologia bernardiniana do anexo) e o poema "Señora, oíd la mi suerte" (n ${ }^{\circ} 3$ da antologia mirandina do anexo) também apresentam o protótipo da mulher do amor medieval: tão cruel que de nada adianta pedir-lhe piedade. Em ambos os poemas, o eu poético pede a morte já que a vida sem o amor da mulher é só sofrimento. No poema de Bernardim Ribeiro, como o desprezo da amada não deixa a "vida viver", ou seja, não permite ao poeta viver plenamente, ele prefere a morte. Esta, apesar de significar o fim, lhe traria ao menos uma definição. Melhor do que uma vida que não é vida. Pela mesma razão, o eu poético do poema de Sá de Miranda pede piedade à morte. Os dois últimos versos do poema abrigam um aparente paradoxo: pedir piedade à morte contra a morte. Mas viver amando uma mulher cruel é morte em vida.

A lírica amorosa medieval de aspecto cortês apresenta um eu poético em profundo sofrimento por causa do amor não correspondido. Essa representação deixa patente que o grande fator de angústia do eu poético é externo ao seu Ser. O eu lírico dessas canções encontra-se a mercê dos caprichos e veleidades da mulher amada. Tal situação não poderia deixar de ser, em algum momento, fonte de transtorno para o eu lírico, como demonstra o poema de Camões, $\mathrm{n}^{\circ} 5$ da antologia camoniana do anexo:

\section{MOTE ALHEIO}

Amor loco, amor loco, yo por vos y vos por otro.

\section{VOLTAS}

Dióme Amor tormentos dos para que pene doblado: uno es verme desamado, otro es mancilla de vos. Ved que ordena Amor em nos: 
porque me vos hacéis loco, que seáis loca por otro!

Tratáis Amor de manera que porque así me tratáis quiere que, pues no me amáis, que améis otro que no os quiera. Mas con todo, si no os viera de todo loca por otro, con mas razón fuera loco.

$Y \tan$ contrario viviendo, alfin, alfin, conformamos, pues ambos a dos buscamos lo que más nos va huyendo. Voy tras vos siempre siguiendo, y vos huyendo por otro: andáis loca, y me hacéis loco. ${ }^{20}$

Tanto o sujeito poético como a amada estão transtornados por esse "amor loco", e a causa é precisamente o fato de estarem incluídos em uma cadeia de amores não correspondidos, a qual já se aludiu. Quanto à questão da posição do elemento angustiante para o eu lírico, Camões deixa claro que ele é externo ao eu que canta, no seguinte soneto, $\mathrm{n}^{\mathrm{o}} 20$ da antologia camoniana do anexo:

Tanto de meu estado me acho incerto que, em vivo ardor, tremendo estou de frio; sem causa, juntamente choro e rio; o mundo todo abarco e nada aperto.

É tudo quanto sinto um desconcerto; da alma um fogo me sai, da vista um rio; agora espero, agora desconfio, agora desvario, agora acerto.

Estando em terra, chego ao Céu voando; num' hora acho mil anos, e é de jeito que em mil anos não posso achar um' hora.

Se me pergunta alguém porque assi ando, respondo que não sei; porém suspeito

\footnotetext{
${ }^{20}$ Luís de Camões. Lírica completa - volume I. Prefácio e notas de Maria de Lurdes Saraiva. Lisboa: Imprensa Nacional - Casa da Moeda, 1980. pp. 41 e 42.
} 
que só porque vos vi, minha Senhora. ${ }^{21}$

No contexto do presente trabalho, poder-se-ia mesmo dizer que é um poema metalingüístico, o qual reflete sobre o tema poético do amor, pois o seu discurso, além de auto explicar-se, tece um esclarecimento sobre um tema presente em outros poemas. O eu lírico descreve pormenorizadamente o seu estado de espírito, e indica categoricamente a causa.

Impossível deixar de mencionar a releitura que se fez no Renascimento do legado platônico. Essa lírica que relê o Platonismo concebe o amor de maneira positiva, entrevendo uma aliança eterna entre amante e amada, no plano metafísico, ou mundo das idéias. Não produz cisão. Antes, pelo contrário, agrega o eu do poeta à amada. Um dos exemplos mais expressivos dessa linhagem poética é o célebre soneto de Camões "Transforma-se o amador na cousa amada", nº 19 da antologia camoniana do anexo:

Transforma-se o amador na cousa amada, por virtude do muito imaginar; não tenho, logo, mais que desejar, pois em mim tenho a parte desejada.

Se nela está minh' alma transformada, que mais deseja o corpo de alcançar?

Em si somente pode descansar, pois consigo tal alma está liada.

Mas esta linda e pura semideia que, como o acidente em seu sujeito, assi com a alma minha se conforma,

está no pensamento como idéia:

o vivo e puro amor de que sou feito, como a matéria simples, busca a forma. ${ }^{22}$

\footnotetext{
${ }^{21}$ Luís de Camões. Lírica completa - volume II. Prefácio e notas de Maria de Lurdes Saraiva. Lisboa: Imprensa Nacional - Casa da Moeda, 1980. p. 40.

${ }^{22}$ idem. p. 265.
} 
Mundo (ou esfera) visível e mundo inteligível são os dois mundos da concepção platônica. $\mathrm{Na}$ esfera ou mundo inteligível habitam as idéias, de que as realidades do mundo visível (ou sensível) são como meras sombras ${ }^{23}$. Se o eu poético já está em companhia de sua amada em um plano tão elevado, não tem "mais que desejar"; e, se as almas estão ligadas (mundo inteligível), qualquer apelo corporal (mundo sensível) de união perde o sentido. Isto é o que transmitem os quartetos. Entretanto, nos tercetos a linguagem do soneto passa a ser aristotélica, fazendo com que a hipótese de confissão platônica deixe de ser pacífica. O primeiro terceto começa inclusive com a conjunção adversativa "mas", indicando que a linha de raciocínio do discurso irá mudar. Camões se aproxima da teoria aristotélica de essência e acidente. Para Aristóteles, a essência corresponde à matéria, que é categoria anterior à realidade; e o acidente corresponde à realidade, que surge da passagem do virtual ao real por meio da intervenção da inteligência, que concretiza ou realiza o acidente a partir da essência. Levando-se em conta o referencial aristotélico, a leitura do poema poderia ser: a idéia pura como a matéria simples, que constitui a amada no plano da essência, busca a realização no acidente, o qual seria a posse do amador. Logo, a efetivação carnal do amor passaria a ser admitida. Não obstante essas leituras filosóficas, Eduardo Lourenço (1983) enquadra o soneto no ciclo de poemas de amor cortês. Segundo ele, a resposta à pergunta “Se nela está minh' alma transformada,/que mais deseja o corpo de alcançar?” seria: nada. Para o estudioso não há Platonismo nem Aristotelismo, mas a típica “dialéctica do amor cortês que tem na ausência ou na impossibilidade da união sem cessar protelada com a bem-amada a sua 'akmé', aqui como que recriada às avessas pelo 'muito imaginar"” (LOURENÇO, 1983, p. 19).

\footnotetext{
${ }^{23}$ Platão, A República, Livro VI, pelo fim; e Livro VII, no início.
} 
Camões também explora essa temática no seguinte poema, $\mathrm{n}^{\mathrm{o}} 12 \mathrm{da}$ antologia camoniana do anexo:

\section{MOTE}

Ferro, fogo, frio e calma

todo o mundo acabarão;

mas nunca vos tirarão,

alma minha, da minha alma.

\section{VOLTA}

Não vos guardei, quando vinha, em torre, força ou engenho; que mais guardada vos tenho em vós, que sois alma minha. Ali, nem frio nem calma não podem ter jurdição; na vida sim, porém não em vós, que tenho por alma. ${ }^{24}$

António José Saraiva (1990) tem entendimento original a respeito do caráter lírico da poesia dos cancioneiros. Segundo o estudioso, ela é dramática e não lírica. Isto se deve à presença de "interlocutores que trocam razões entre si" (SARAIVA, 1990, p. 181). Estes interlocutores não constituem um coro como o de uma composição a várias vozes, mas personagens que interagem trocando opiniões e pontos de vista. Tal entendimento, ainda que em princípio dirigido às cantigas de amigo, poderia ser eventualmente aplicado a algumas obras incluídas no nosso corpus poético, o que tornaria injustificável a sua inclusão no referido corpus. Logo, tornam-se necessárias algumas considerações, com o objetivo de sustentar o nexo global do trabalho.

\footnotetext{
${ }^{24}$ Luís de Camões. Lírica completa - volume I. Prefácio e notas de Maria de Lurdes Saraiva. Lisboa: Imprensa Nacional - Casa da Moeda, 1980. p. 139.
} 
Entendemos que, no presente caso, tal juízo crítico carece de irrestrita aplicabilidade. O referencial teórico mediante o qual o Professor Saraiva fundamenta o seu entendimento parece encontrar-se claramente nos seguintes excertos:

Está hoje posto em discussão o velho hábito de considerar a obra literária de dois pontos de vista ou em duas metades: a Forma e a Substância, entendendo-se por Substância o material de sentimentos e idéias que o autor pretende exprimir e por Forma o molde onde esse material toma corpo e aparência externa. Na verdade, as duas coisas são por tal forma solidárias que fazem um bloco só; e a Substância só existe com a Forma, do mesmo modo que não existe Forma sem Substância.

$$
[\ldots]
$$

Sendo assim, dir-se-ia uma ilusão tradicional esta partição em duas metades da obra literária. Todavia, se é verdade que a Substância acompanha sempre a Forma, não menos verdade é que a mesma substância pode cristalizar em várias formas e que na mesma forma podem conter-se, umas atrás das outras, substâncias várias: quem não conhece certos lugares-comuns repisados através dos tempos de maneiras variadíssimas?

\section{$[\ldots]$}

Há portanto uma verdade escondida no fundo da velha distinção de Forma e Substância.

$[\ldots]$

Dentro desta interpretação, Forma e Substância são inseparáveis, porque, sendo a forma a vibração, o movimento, a dinamização - isto é, um estado da Substância -, é por ela que a Substância se torna sensível, luminosa, vibrante, emergindo do fundo tenebroso e silencioso do espírito criador. Mas, ao mesmo tempo, Forma e Substância têm de ser consideradas separadamente, porque constituem duas séries perfeitamente distintas de fenómenos. ${ }^{25}$

O que António José Saraiva chama de "Forma e Substância" pode ser igualmente referido como forma e conteúdo do discurso literário ${ }^{26}$. Baseado nessas categorias, o Professor Saraiva sustenta que, tanto na forma como no conteúdo, a poesia dos cancioneiros não é lírica, mas dramática, já que há interlocutores (forma de drama) e diálogo com argumentação reciprocamente destinada entre eles (conteúdo de drama). Segundo ele, a classificação como lírica da poesia compilada nos cancioneiros posteriores à

\footnotetext{
${ }^{25}$ António José Saraiva, Poesia e drama, Lisboa: Gradiva, 1990, pp. 52-54.

${ }^{26}$ Veja-se: Antonio Candido. O estudo analítico do poema. $3^{\text {a }}$ edição. São Paulo: Humanitas Publicações FFLCH/USP, 1996.
} 
morte de Afonso X-o-Sábio serviu para marcar uma distinção nítida entre as literaturas portuguesa e castelhana. Esta última de cariz épico nos seus primórdios.

Tome-se o seguinte poema de Camões, de número 11 na antologia camoniana do anexo:

\section{VILANCETE PASTORIL}

- Deus te salve, Vasco amigo!

Não me falas? Como assi?

- Bofé, Gil, não estava aqui...

\section{VOLTAS}

- Pois onde te vão falar, se não estás onde apareces?

- Se Madanela conheces, nela me podes achar.

- E como te hã-de ir buscar aonde fogem de ti?

- Pois nem eu estou em mi...

- Porque te não acharei em ti, como em Madanela? - Porque me fui perder nela o dia que me ganhei.

- Quem tão bem fala, não sei como anda fora de si.

- Ela fala dentro em mi.

- Como estás aqui presente, se lá tens a alma e a vida?

- Porque é de ũa alma perdida aparecer sempre à gente.

- Se és morto, bem se consente que todos fujam de ti.

- Eu também fujo de mi. ${ }^{27}$

\footnotetext{
${ }^{27}$ Luís de Camões. Lírica completa - volume I. Prefácio e notas de Maria de Lurdes Saraiva. Lisboa: Imprensa Nacional - Casa da Moeda, 1980. pp. 109 e 110.
} 
Tomando por base o referencial teórico de que se vale António José Saraiva, chega-se a conclusão de que o poema é dramático. A estrutura externa, ou seja, a forma é de um drama: dois personagens em diálogo, com todos os sinais de pontuação indicativos. O conteúdo, a primeira vista, também, pois há uma interação dinâmica entre os personagens, que evolui em forma de trama por meio de uma tensão, pois ambos se contradizem reciprocamente até a asserção irrespondível do último verso. O poema poderia mesmo - não sem prejuízo do seu real significado literário - ser encenado, ou inserido em uma peça como adaptação. Entretanto, o conteúdo e a idéia são líricos. Há um sujeito poético falando de si, do seu estado de espírito por causa de um amor infeliz. Vasco é na verdade o eu poético do poema; e Gil, apenas um apoio lingüístico para que o discurso exprima o que o sujeito poético sente.

O poema se inicia com Gil falando a Vasco sem obter resposta do amigo que está distraído. Quando Vasco se dá conta de que Gil lhe fala, responde dizendo que não estava ali, o que causa estranheza em Gil. Na primeira volta, Vasco esclarece que estava em Madanela. Mas quem está falando é o eu lírico, dizendo que está em pensamento com a amada. Nos versos 8 e 9, fica demonstrado que o amor não é correspondido, de acordo com a fórmula do amor cortês. $\mathrm{O}$ verso 10 já exprime a cisão do eu lírico pelo motivo externo: o eu não está em si, mas no objeto amado. Gil, para quem Vasco também não está em Madanela, pois esta não o ama, não compreende como pode ser isso. Vasco responde engenhosamente e Gil pergunta como alguém que está fora de si articula idéias tão bem. O eu lírico na voz de Vasco reitera que amante e amada se fundiram. Gil tenta encurralar o amigo perguntando como pode ele estar ali se sua alma está alhures. Vasco se apresenta como uma assombração. Gil é sarcástico com a dor do amigo e diz que é natural que qualquer um (inclusive Madanela) fuja de um morto. O último verso retoma os versos 10 e 
17 e sintetiza todo o fatalismo da cisão. A amada está dentro da alma do eu lírico e, como ela não o ama, ele tem que fugir de si para minimizar o seu sofrimento.

No corpus poético deste trabalho, todo poema representativo do amor cortês medieval está marcado por características dramáticas, no sentido de que há um tu subjacente ao eu que canta. Esse tu é invariavelmente a amada, o que confere aos poemas o tom de ode. Isso não significa, em hipótese alguma, que sejam poemas dramáticos. São poemas líricos. Kayser (1967) estabeleceu uma categorização apropriada para o estudo dessa questão. Segundo ele, os gêneros literários não se manifestam apenas por meio de formas exteriores de apresentação, que engendram classificações demasiado estanques, mas também através de "formas naturais" e "atitudes básicas".

Kayser (1967) concebe três atitudes líricas fundamentais: enunciação lírica (lyrisches Nennen), apóstrofe lírica (lyrisches Ansprechen) e linguagem da canção (liedhaftes Sprechen). A primeira apresenta uma tendência épica; a segunda, uma tendência dramática; e a terceira é a mais autenticamente lírica. A ode é uma das três singularizações da apóstrofe lírica, juntamente com o hino e o ditirambo. Caracteriza-se por um tu próximo do eu lírico e acessível a sua contemplação pela possibilidade do encontro, ao passo que no hino e no ditirambo o tu se reveste de caracteres sobre-humanos e o encontro é impossível. A linguagem da ode é também mais racional e circunspeta. Da possibilidade do encontro advêm regras claras: o eu e o tu estão obrigados a examinarem-se mutuamente e a tomar uma posição reciprocamente considerada. No caso da poesia lírica de amor cortês, o eu lírico ama e a amada não. Logo, adotando-se este referencial teórico e estando presentes as características mencionadas, os poemas de amor cortês do corpus são poesia lírica marcada pela atitude da apóstrofe lírica. 
Quanto à possibilidade infinitamente menos provável de que algum poema seja tido como narrativo ou descritivo, épico, portanto, cabe um rapidíssimo esclarecimento. Kayser (1967), conforme o retro explicado, concebe uma atitude épica dentro do lírico designada por enunciação lírica. Tal atitude configura-se quando o eu lírico se depara com algo que tem existência real, capta suas características e passa a exprimi-lo. Assim se passa com o poema "Retrato, vós não sois meu" (n 16 da antologia camoniana do anexo):

\section{MOTE}

Retrato, vós não sois meu. Retrataram-vos mui mal: que, a serdes meu natural, fôreis mofino como eu.

\section{GLOSA}

Inda que em vós a arte vença o que o natural tem dado, não fostes bem retratado, que há em vós mais diferença que do vivo ao pintado. Se o lugar se considera do alto estado que vos deu a sorte, que eu mais quisera, se é que eu sou quem de antes era, retrato, vós não sois meu.

Vós na vossa glória posto, eu na minha sepultura; vós com bens, eu com desgosto; parecei-vos ao meu rosto, e não já à minha ventura. E pois nela e vós erraram o que em mim é principal, muito em ambos se enganaram. Se por mim vos retrataram, retrataram-vos mui mal.

Mas se esse rosto fingido 


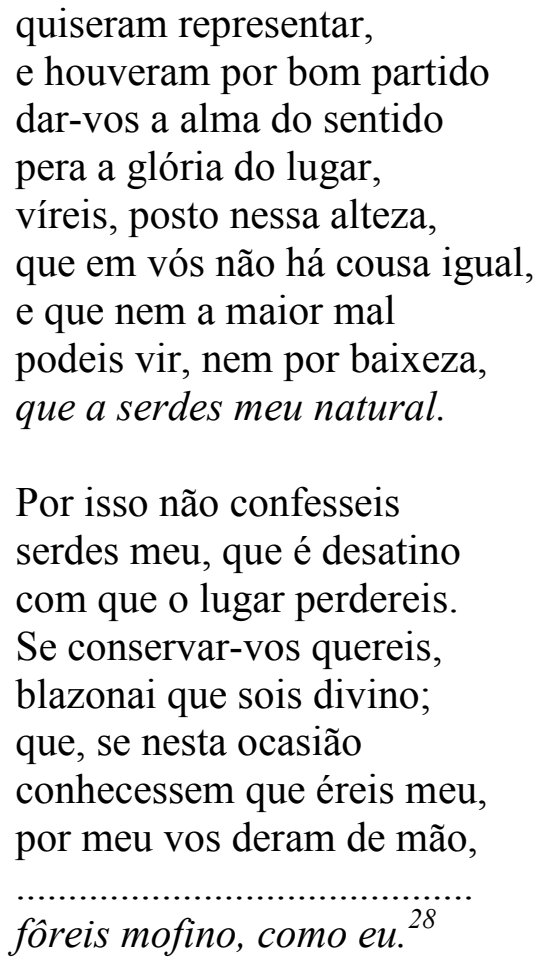

Este famosíssimo poema, ainda em medida velha, é um exemplo notável de lirismo impregnado de enunciação lírica, já que o texto é também descritivo. No entanto, o sujeito poético aproveita o ensejo de estar comentando um retrato seu para falar de si. O retratado é o eu lírico falando. O eu poético do poema é tudo aquilo que o retrato não é, numa espécie de identidade pela via da alteridade. Evidentemente, o retrato pode ser tido como um duplo sob a forma de contraponto geral e absoluto do eu que canta. No retrato, a arte vence porque é a representação do belo e o retratado é feio; o retrato é glorioso porque o retratado é miserável; o retrato só é mau na hipótese de o retratado ser realmente o modelo. Por isso, o poeta conclama o retrato a rejeitá-lo como modelo e antes blasonar que é divino, pois todos acreditarão.

\footnotetext{
${ }^{28}$ Luís de Camões. Lírica completa - volume I. Prefácio e notas de Maria de Lurdes Saraiva. Lisboa: Imprensa nacional - Casa da Moeda, 1980. p. 220 e 221.
} 
O desdobramento do eu - ou seja, a cisão propriamente dita - motivado por fatores internos é um tema que se generalizou na lírica moderna, mas na literatura portuguesa também é um fenômeno antigo. No século XVI, isto é, muito antes do processo que desencadeou a renovação poética da Lírica, a poesia portuguesa já apresentava essa cisão. A mentalidade atormentada do período que corresponde à crise da Renascença e o advento do Maneirismo como estilo de transição entre aquela e o Barroco está presente com toda a sua força na lírica portuguesa. Como frisa Severo Sarduy (1979, p. 57), “o barroco estava destinado, desde o seu nascimento, à ambigüidade, à difusão semântica”.

A partir da renovação da Lírica - que, embora tenha sido um processo, tem seu momento decisivo na publicação das Flores do mal de Charles Baudelaire, em 1857 -, o problema poético foi deslocado de uma causa externa (o objeto do amor que não corresponde a este sentimento) para uma causa interna: os problemas e questões de foro íntimo. Estes imponderáveis por sua própria natureza, como os recalques e frustrações tratadas pela psicanálise. Este mergulho íntimo, entendido como o recolhimento em um espaço anímico (FRIEDRICH, 1991), passa a ser uma intimidade comunicativa quando resulta em fazer poético, e a literatura do eu é uma conseqüência discursiva do mergulho íntimo. O amor como fator de fragmentação do eu evolui de uma situação externa para uma situação interna, o que aumenta potencialmente a sua capacidade dilacerante. A renovação poética da Lírica está intimamente relacionada ao Simbolismo, que abriu caminho para as vanguardas do século XX.

Tal reviravolta não se operou de maneira abrupta, mas paulatina. $\mathrm{O}$ pensamento filosófico do século XVII (sobretudo cartesiano) já havia modificado substancialmente a forma de entender o Ser. O alargamento da consciência moral do 
homem veio acompanhado de um alargamento da autoconsciência. Conforme ensina Norbert Elias (1994, p. 91):

Se as pessoas do nível precedente de autoconsciência se haviam percebido, em consonância com sua educação e seu estilo de vida, como membros de associações tais como grupos familiares ou Estados inseridos num reino espiritual governado por Deus, passaram então a se perceber cada vez mais como indivíduos, embora sem perder inteiramente a antiga concepção. ${ }^{29}$

Se antes de René Descartes o duplo do homem é objetivo - ou seja, Deus - após as pesquisas do filósofo ele passa a ser subjetivo. Até então, o pensamento filosófico-teológico dominante era de que o homem é feito à imagem e semelhança de Deus: este é o único duplo possível para qualquer ser humano. René Descartes passa a deduzir do eu as verdades morais e metafísicas que antes eram deduzidas de Deus. Na sua análise, Descartes coloca o sujeito como centro do mundo ${ }^{30}$. Mas, ainda que influente e inovador, o pensamento cartesiano não é totalmente carecedor de precedentes no que se refere a sua maneira de encarar o Ser. Como adiante se verá, Giovanni Pico Della Mirandola já investigava a natureza humana como coisa singular.

Já Luiz Costa Lima (2005, p. 21) entende que a fundamentação do sujeito moderno está na reflexão kantiana, e não no cogito cartesiano. Entretanto, Kant legitima o eu na relação com a experiência social, ou seja, seu caráter de cidadão (COSTA LIMA, 2005, p. 113). Mas o espaço anímico no qual se desenvolve a Lírica pressupõe um sujeito voltado para o seu próprio interior. Além disso, a identificação do indivíduo com o cidadão implica uma construção do conceito de eu baseada no sujeito biográfico. E a lírica

\footnotetext{
${ }^{29}$ Norbert Elias. A sociedade dos indivíduos. Organizado por Michael Schröter. Tradução de Vera Ribeiro. Revisão técnica e notas de Renato Janine Ribeiro. Rio de Janeiro: Jorge Zahar Editor, 1994.

${ }^{30}$ René Descartes. Discurso do Método para conduzir bem sua razão e buscar a verdade nas ciências e mais a Dióptrica, os Meteoros e a Geometria que são ensaios dêsse método. Tradução, introdução e notas de João Cruz Costa. Rio de Janeiro: Edições de Ouro, 1965. Quarta Parte.
} 
moderna, ainda que centrada no eu, não é autobiográfica. $\mathrm{O}$ eu lírico não é sujeito biográfico, mas sujeito poético. As definições de gênero autobiográfico trazem, invariavelmente, uma menção ao autor ou escritor. Segundo o próprio Costa Lima (2005, p. 193), “é inquestionável que a centralidade no indivíduo exclui a imagem do cidadão, de que não se afastara o pensamento kantiano”.

O eu lírico atormentado em virtude de questões de foro íntimo, tão comum na lírica moderna, já estava presente no Quinhentismo literário português. Camões, Bernardim Ribeiro e Sá de Miranda deram igualmente tratamento poético aos motivos externos e internos de angústia existencial. Veja-se o que canta Camões, no poema "De dentro tengo mi mal" ( $n^{\circ} 1$ do anexo):

\section{MOTE ALHEIO}

De dentro tengo mi mal, que de fuera no hay señal.

\section{VOLTA}

Mi nueva y dulce querella

es invisible á la gente:

el alma sola la siente,

que el cuerpo no es dino della.

Como la viva centella

se encubre en el pedernal,

de dentro tengo mi mal. ${ }^{31}$

O mote é categórico: o mal está dentro e, para o observador externo ao Ser do eu que canta, é imperceptível. No primeiro verso da volta, o sujeito poético identifica o desconforto interno como fato novo. E, no último, reafirma que o fator de angústia para o eu lírico é interno. Sobre questão idêntica, vejam-se os poemas "Triste vida

\footnotetext{
${ }^{31}$ Luís de Camões. Lírica completa - volume I. Prefácio e notas de Maria de Lurdes Saraiva. Lisboa: Imprensa Nacional - Casa da Moeda, 1980. p. 43.
} 
se me ordena", "Vede bem se nos meus dias" e "Os bons vi sempre passar" (respectivamente de números 4, 6 e 10 da antologia camoniana no anexo). Veja-se agora o poema "Nada quero, tudo enjeito", de Bernardim Ribeiro (n 3 da antologia bernardiniana do anexo), e também "Entre tamanhas mudanças" e "Para tudo houve remédio" (estes no anexo e correspondentes aos de números 7 e 12 da antologia bernardiniana):

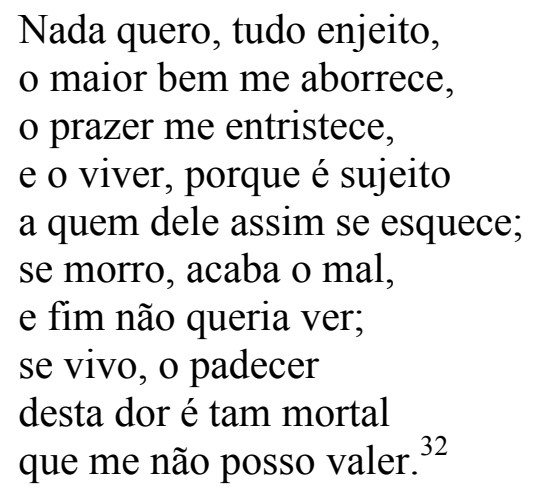

Nenhum dos autores que compõem o corpus quinhentista trabalhou tanto a questão do eu lírico angustiado por problemas internos como o poeta filósofo Sá de Miranda. Sua obra fornece exemplos em profusão dessa temática. Vejam-se os poemas "Puédese esta llamar vida" e "Deixai-me as minhas tristezas", respectivamente 6 e 12 da antologia mirandina do anexo:

\section{6}

Puédese esta llamar vida: a la qual se entra llorando, que se pasa suspirando, la muerte es la su salida?

Por lo qual yo, sin ventura, con gran cuita, he deseado que huviera sido llevado del parto a la sepultura; tal esperanza perdida, yo no sé, loco, trás que ando; voyme así devaneando entre la muerte y la vida. ${ }^{33}$

\footnotetext{
${ }^{32}$ Bernardim Ribeiro. op. cit., p. 179.

${ }^{33}$ Francisco de Sá de Miranda, op. cit., p. 8.
} 
12

Deixai-me as minhas tristezas, que já'gora outra alegria maior perigo seria.

Aos males acostumados o mesmo costume é cura. Bens tam vãmente esperados, quem os sofre? E quem atura senão desapaixonados?

Criei-me com meus cuidados; já agora não saberia andar noutra companhia. ${ }^{34}$

No primeiro poema, tem-se um sujeito poético que reflete sobre a vida e percebe que "vida" é indevidamente uma palavra com carga semântica positiva, pois passase toda ela sofrendo; ou, sendo de fato uma palavra semanticamente positiva, não se pode aplica-la à existência humana. Este poema guarda estreita relação com o poema "Ay, qué vida tan esquiva" ( $\mathrm{n}^{\circ} 28$ da antologia mirandina do anexo), não só pelo conteúdo mas também pela utilização da imagem "del parto a la sepultura", que reaparece como "del vientre a la sepultura". Em ambos os poemas, o sujeito poético queixa-se da vida, a qual é irremediavelmente um vale de lágrimas entre os dois cumes: nascimento e morte. Mas essa imagem constitui também um tópico próprio: a visão da vida como fonte de irremediável sofrimento e sem espaço para o mais efêmero momento de felicidade. Veja-se o soneto "O dia em que naci moura e pereça", de Camões, correspondente ao poema 23 da antologia camoniana do anexo.

O sujeito poético do segundo poema parece ter encontrado uma solução para os seus problemas íntimos: resignar-se. O eu que canta cura-se dos seus males e

\footnotetext{
${ }^{34}$ Idem, p. 20 e 21.
} 
cuidados, habituando-se a eles. O poema guarda estreita relação com o poema "Acostumeime aos meus males" ( $\mathrm{n}^{\mathrm{o}} 25$ da antologia mirandina do anexo). Neste, o sujeito poético acostuma-se de tal forma a seus males, que passou a apreciar a companhia dos mesmos. Quando não há males para chorar, chora de saudade deles. Vejam-se ainda os poemas "Mal, de que me eu contentei”, "Que mal avindos cuidados”, "Toda esperança é perdida", "Como não quereis que seja", "Fuye el tiempo, está el mal quedo", "De quem me devo queixar", "Alma tam sem assossego", "Em tormentos cruéis, tal sofrimento" (respectivamente de números 7, 9, 13, 14, 20, 23, 24 e 31 da antologia mirandina do anexo) e o poema "Cuidados, assim vos quero" ( $n^{\circ} 9$ da antologia bernardiniana do anexo).

A pluralidade de sentimentos e de maneiras de reagir a eles engendrou a cisão do eu lírico em inúmeras obras poéticas do Quinhentismo literário português. Tomese como exemplo inicial, pois no próximo capítulo o tema será desenvolvido plenamente, o poema "Triste vida se me ordena" ( $\mathrm{n}^{\mathrm{o}} 4$ da antologia camoniana do anexo). A mulher amada retribui o bem com o mal ao poeta, o que é condizente com a dialética do amor medieval. Mas no quarto e quinto verso da segunda estrofe da glosa nota-se que, sendo a mulher o elemento angustiante, o sujeito poético reconhece que ele mesmo é contra si, pois sabendo que não é amado insiste em amar. As duas glosas que faz Camões ao mesmo mote "Sem vós e com meu cuidado" e que correspondem aos poemas 13 e 14 da antologia camoniana em anexo desenvolvem temática análoga: o fator externo (não possuir a mulher amada) uniu-se ao fator interno (os cuidados). $\mathrm{O}$ mote, que forma um quiasmo, resume o problema. Além da frustração amorosa por não desfrutar da companhia da amada ("sem quem"), o eu lírico ainda precisa conviver com os seus cuidados (“com quem"). Nos quatro primeiros versos da segunda estrofe da glosa, o eu lírico se vê impossibilitado de saber qual 
dos males que constituem os termos do quiasmo é mais estranho: o "não vos ver" (sem quem) ou o "imigo tamanho" (com quem).

Vejam-se os dois poemas seguintes (na verdade duas versões do mesmo poema, sendo o segundo erroneamente atribuído a Bernardim Ribeiro por Delfim Guimarães, ainda que este ressalve o fato de constar o poema no Cancioneiro Geral de Garcia de Resende como de autoria de Sá de Miranda), e que correspondem ao poema 5 da antologia mirandina do anexo:

Que é isto? Onde me lançou esta tempestade má?

Qu'é de mi, se não sou lá, e cá comigo não vou?

Inda que me eu cá não via, tudo vos confessarei: onde a vós e a mi deixei cuidava que me acharia; agora quem, donde estou, novas de mi me trará? Pois dizeis que não sou lá, não sei sem mi onde vou. ${ }^{35}$

Coitado! Quem me dará novas de mim? Onde estou, pois dizeis que não sou lá, e cá comigo não vou?

Todo êste tempo, senhora, sempre por vós preguntei, mas que farei, que já agora de vós nem de mim não sei? Olhe vossa mercê lá se me tem, se me matou, porque eu vos juro que cá morto nem vivo não vou.

\footnotetext{
${ }^{35}$ Idem, p. 7.
} 
O tom da primeira versão é de total perplexidade do sujeito poético. $\mathrm{O}$ sujeito pensava encontrar-se junto do objeto do amor, ou seja, a amada, como em "Transforma-se o amador na cousa amada" ou no vilancete pastoril de Camões. Por algum motivo desconcertante (a "tempestade má"), ele se perdeu de si e da amada. E o futuro é incerto, pois o sujeito não sabe quem lhe trará novas de si, no ignoto lugar onde se encontra. A segunda versão apresenta uma interessante representação poética da cisão, que se reveste antes de apatia que de perplexidade por parte do sujeito. Não há animosidade de si contra si. O sujeito cansou de tanto buscar a amada e tornou-se apático. De perguntar por ela, passou a perguntar de si a ela. Não consegue mais ver-se. As duas versões parecem mesmo dois poemas distintos sobre tema análogo, um citando o outro, tamanha é a dessemelhança entre eles. Os pontos de conexão, onde ocorre a intertextualidade sob a forma de citação, estão nos versos 3 e 4 da primeira estrofe de ambas as versões e nos versos 5 e 6 da segunda estrofe da primeira versão, que correspondem aos versos 1 e 2 da primeira estrofe da segunda versão.

A grande utopia renascentista de equilíbrio absoluto e perfeita harmonia sufocou o espírito naturalmente caótico do homem do século XVI. O artista se via obrigado a representar na sua arte algo que não tinha correspondência no próprio ser. Essa harmonia artificial e fictícia estava fadada a desmoronar, já que era fruto de uma arte ilusória, quimérica. A crise da Renascença se torna mais clara na crise do Humanismo, o qual era inspirado no Estoicismo, cuja filosofia entendia que se atinge a condição humana mediante a educação e a auto-disciplina ${ }^{36}$. Esta era uma das ficções renascentistas: a crença estóica

\footnotetext{
${ }^{36}$ Veja-se "Sêneca" e "Marco Aurélio" em Alexandre Caballero, A filosofia através dos textos. São Paulo: Cultrix, 1972. pp. 63-72.
} 
na capacidade de controle total e absoluto de todas as paixões, de maneira que razão e emoção formassem uma unidade harmoniosa.

As grandes transformações sócio-econômicas, o esfacelamento do modelo de organização social anterior e a grande ampliação dos horizontes humanos representada pela recente descoberta das reais dimensões do mundo que vieram com a passagem da Idade Média para a Idade Moderna mostraram ao homem do século XVI que a vida evolui por meio de tensões, o que difere da concepção renascentista de equilíbrio. Pela simples observação das vicissitudes do cotidiano era possível verificar que os paradoxos abundavam na vida real. Uma representação artística honesta deveria expor essa vinculação paradoxal de elementos inconciliáveis. $\mathrm{O}$ Maneirismo ${ }^{37}$ só pode ser entendido como o produto da tensão entre valores conflitantes.

O período em questão assiste ao aparecimento de um novo conceito de indivíduo. Este passa a ser entendido como um ser diferenciado do corpo social no qual está inserido e dotado de características próprias e idiossincráticas. A partir dessa concepção de individualidade, nasceu o conceito de gênio e a idéia da obra de arte como criação deste, diferentemente da concepção medieval, que não conferia valor intrínseco à originalidade e não conheceu a competição intelectual tal como passou a existir posteriormente.

No que se refere à subjetividade na Literatura, Costa Lima (2005, p.22) propõe, a partir do estudo da obra de Montaigne, que duas concepções de Literatura

\footnotetext{
${ }^{37}$ Arnold Hauser. Maneirismo - a crise da Renascença e o surgimento da arte moderna. $2^{\mathrm{a}}$ edição. São Paulo: Editora Perspectiva, 1993.
} 
contrapõem-se: a renascentista, que entende a Literatura como a prática das belas letras; e a moderna, baseada no sujeito individual. Costa Lima (2005, p. 25) entende que a autonomia do eu é marca da Modernidade, ao passo que o mundo antigo era regido pela "ordem da mimesis", na qual a individualidade só existe em conexão com a comunidade. $\mathrm{Na}$ antiguidade, o indivíduo sempre pressupunha o grupo. Montaigne estaria no limite tênue entre as duas tendências, seu discurso é, a um tempo, conservador e subversivo. Para o estudioso (2005, p. 37), o eu se "desgarra e autonomiza" em Montaigne.

Essa nova concepção de indivíduo possibilita a introspecção do poeta, o mergulho sobre si mesmo e seus pensamentos. E a descoberta que o sujeito poético faz nesse mergulho íntimo é assustadora: o poeta encontra dentro de si, e a dilacerar-lhe o eu interior, os mesmos paradoxos e elementos desagregadores que existem no mundo. Dessa forma, o mergulho íntimo é extremamente angustiante para o sujeito poético. Este nada encontra na própria intimidade além do conflito, o qual expressa a ambivalência das atitudes humanas. Este conflito interior é o estopim para a fragmentação do sujeito poético, o qual se dá por duas oposições: a de sensações conflitantes dentro do mesmo ser e a cisão do Ser em dois ou mais entes antagônicos. 


\section{Pico Della Mirandola, Sá de Miranda, Ribeiro, Camões e o inimigo de si}

A interiorização do fator de perturbação da ordem íntima, como temática lírica na Literatura de todas as línguas, está incontestavelmente relacionada à influência simbolista baudelaireana. Mas na lírica portuguesa - e isto foi o que suscitou a idéia de realizar esta monografia - a desordem íntima motivada por um questionamento da subjetividade já aparecia em profusão desde o século XVI, como foi cabalmente demonstrado. Não se pretende aqui sustentar a idéia de que a grande renovação da Lírica, que abriu as portas para o advento da estética modernista, ocorreu no Quinhentismo literário português. Pretende-se apenas demonstrar que a poesia lírica portuguesa do século XVI apresenta traços de indiscutível modernidade.

A poesia quinhentista portuguesa insere-se no contexto da Renascença, seu conteúdo temático é renascentista. Até mesmo quando se revela moderna. E isso não é de forma alguma paradoxal quando se analisa a visão de mundo e de homem introduzida pelo Renascimento, numa obra filosófica deste período: o Discurso sobre a dignidade do homem, de Giovanni Pico della Mirandola ${ }^{38}$. A obra do filósofo italiano ganha tal importância por sintetizar e expressar magistralmente a mentalidade da Renascença. Mas não se limita a isso. O pensamento piquiano projeta-se para o futuro, é atemporal e atualiza-se permanentemente, já que é recepcionado em épocas subseqüentes à sua ${ }^{39}$, assim como a poesia quinhentista.

\footnotetext{
${ }^{38}$ Giovanni Pico Della Mirandola. Discurso sobre a dignidade do homem. Edição bilíngüe. Tradução de Maria de Lurdes Salgado Ganho. Lisboa: Edições 70, 2006.

${ }^{39} \mathrm{O}$ existencialismo de orientação sartreana recepciona as idéias piquianas de maneira notável, conforme se verifica no opúsculo $O$ existencialismo é um humanismo. Nele, Sartre propõe que a existência precede a essência. O homem primeiramente existe, encontra a si mesmo, para então definir-se. Como se verá, Giovanni Pico preconizava que o homem é um ser indefinido e livre para definir-se por meio do uso da razão. Logo, estabelece-se claramente uma afinidade de pensamento entre os dois filósofos.
} 
O pensamento de Giovanni Pico tem aspecto duplo: é uma filosofia da ação conjugada com uma atitude mística. Ao dignificar o homem na sua dimensão terrena, pela defesa da busca da felicidade, Pico não exclui a relação do homem com Deus. É a aplicação prática da sua tese sobre a "concórdia" entre a ratio philisophica e a ratio theologica.

O humanismo de Pico promove a valorização do homem e não apenas das humanidades. Nos seus estudos de retórica, diferencia claramente sapiência de eloqüência, contestando o valor epistemológico do humanismo centrado no domínio filológico, pois este dá demasiado destaque à erudição e à eloqüência. Estas se tornam vazias de sentido prático se têm como principal objetivo aperfeiçoar a capacidade de persuasão do discurso retórico. Note-se que, com isso, o discurso poético recobra importância, enquanto faculdade de elevadíssimo teor humano. Conforme salienta Pina Martins (1991, p. 1028), “a palavra poética, no Renascimento, assume a dignidade reivindicada pelos humanistas para o próprio homem". Pico rejeita o beletrismo decorativo da cultura de salões. A sua visão da linguagem é notável. Para ele a elegância estilística não é um fim em si mesma, mas uma ferramenta para a busca da verdade. Tal busca é identificada com a filosofia.

A Oratio de hominis dignitate se desenvolve por centros de reflexão. $\mathrm{O}$ retorno e o emprego dos filósofos antigos (da antiguidade clássica greco-romana) e da fortuna crítica sobre eles disponível era o ponto de partida para um processo de assimilação de todo este conteúdo informacional, que adquiria um caráter existencial na mente do 
filósofo renascentista e era exteriorizado sob a forma de uma concepção filosófica nova, forjada pelo enfrentamento crítico da antiguidade clássica greco-romana.

A dignidade do homem deriva da posição central que Giovanni Pico Della Mirandola lhe atribui dentro da sua concepção de Universo. O antropocentrismo de Pico toma o homem como ponto de referência para a realidade. Tal é o alcance ontológico, metafísico e ético da sua obra. Na Oratio, encontram-se três planos de investigação filosófica ou níveis de inteligibilidade: o problema da Razão, que se exercita pela dialética; o problema da Liberdade, que implica escolhas de ordem ética; e o problema do Ser, eminentemente metafísico. Na articulação dessas três questões ao longo da obra, Giovanni Pico entende a razão humana como poder indagador; a filosofia, como discurso da razão; e afirma ser o filósofo um ser privilegiado por discernir "com recta razão".

A razão permite ao homem tomar consciência da sua liberdade, a qual é a dimensão ética do ser humano. A dignidade do homem se deve ao fato de ser ontologicamente de natureza indeterminada, ou melhor, não pré-determinada, pois é artífice de si mesmo. O destino humano não está determinado a priori, mas determina-se, condiciona-se a posteriori. Uma vez que pode ser animal ou divino, o homem encontra-se a meio caminho entre os irracionais e os anjos. O homem está "condenado" à liberdade, é dono do seu destino. Como se nota no excerto que segue, Giovanni Pico recepciona o mito platônico do Protágoras, segundo o qual Deus, no ato da Criação, distribuiu entre as suas criaturas dons particulares e, quando chegou o momento de definir o caráter humano, como todos os dons já haviam sido concedidos, ao homem foi permitido escolher por si quais seriam os seus dons. 
Ó suma liberdade de Deus pai, ó suma e admirável felicidade do homem! ao qual é concedido obter o que deseja, ser aquilo que quer. As bestas, no momento em que nascem, trazem consigo do ventre materno, como diz Lucílio, tudo aquilo que depois terão. Os espíritos superiores ou desde o princípio, ou pouco depois, foram o que serão eternamente. Ao homem nascente o Pai conferiu sementes de toda a espécie e germes de toda a vida, e segundo a maneira de cada um os cultivar assim estes nele crescerão e darão os seus frutos. Se vegetais, tornar-se-á planta. Se sensíveis, será besta. Se racionais, elevar-se-á a animal celeste. Se intelectuais, será anjo e filho de Deus, e se, não contente com a sorte de nenhuma criatura, se recolher no centro da sua unidade, tornado espírito uno com Deus, na solitária caligem do Pai, aquele que foi posto sobre todas as coisas estará sobre todas as coisas. ${ }^{40}$

Entretanto, a liberdade do homem deve estar orientada para o bem se tiver pretensões verdadeiramente humanas. Logo, dentro dos limites e possibilidades da ação humana, o homem deve agir objetivando os valores mais altos, conforme se depreende do excerto que se segue:

[...] que compreendamos, a partir do momento em que nascemos na condição de sermos o que quisermos, que o nosso dever é preocuparmonos sobretudo com isto: que não se diga de nós que estando em tal honra não nos demos conta de nos termos tornado semelhantes às bestas e aos estúpidos jumentos de carga. [...] De tal modo que, abusando da indulgentíssima liberalidade do Pai, não tornemos nociva, em vez de salutar, a livre escolha que ele nos concedeu. Que a nossa alma seja invadida por uma sagrada ambição de não nos contentarmos com as coisas medíocres, mas de anelarmos às mais altas, de nos esforçarmos por atingi-las, com todas as nossas energias, desde o momento em que, querendo-o, isso é possível. ${ }^{41}$

Por ser livre, o homem é superior a todos os seres criados. Como pode ser tudo, mediante a sua ação no mundo, o homem possui uma fantástica riqueza ontológica. A indefinição ôntica do ser humano é conseqüência do seu poder de auto determinar-se.

\footnotetext{
${ }^{40}$ Giovanni Pico Della Mirandola, Discurso sobre a dignidade do homem, Lisboa, Edições 70, p. 57.

${ }^{41}$ Idem, p. 61.
} 
No pensamento piquiano, destaca-se a sua vertente ética, pois a salvação se dá pela via moral. Daí decorre a peremptória rejeição da astrologia. Giovanni Pico nega qualquer valor epistemológico à astrologia porque a aceitação de que os astros influenciam a vida humana é incompatível com a tese do livre-arbítrio, pois implicaria necessariamente um determinismo no agir humano. Do plano ético também decorre o reconhecimento de dois tipos de magia. A má magia, diabólica e praticada secretamente, é rejeitada pela axiologia piquiana, pois não corresponde a uma prática elevada. A boa magia, natural, antecessora da ciência experimental moderna, é compatível com a dignidade do homem, pois supõe conhecimento e domínio da natureza por meio da Razão.

A concórdia, enquanto conciliação universal entre todas as vertentes de pensamento, também é tema central da Oratio. É apresentada em três instâncias: unidade da religião; unidade de pensamento; e unidade da verdade.

A unidade da religião tem no Cristianismo o seu grande catalisador. $\mathrm{O}$ Cristianismo seria a grande síntese teológica. Isso está em consonância com a concepção aristotélico-tomista dos "Estados Perfeitos", isto é, aqueles que se completam em si mesmos, sem subordinação a nada. Como os fins visados pela associação humana compreendem a ordem temporal e a ordem atemporal, são eles a Sociedade Civil e a Sociedade Religiosa. Ambos são perfeitos, completos e soberanos. A idéia de Sociedade Civil foi o ponto de partida para o conceito tomista do que hoje se chama Estado. Conforme doutrinou Santo Tomás de Aquino: Civitas est communitas perfecta ${ }^{42}$. Na Sociedade Religiosa, enquanto liga espiritual, o homem subordina-se às leis da natureza e à soberania de Deus. Para esta concepção, a Sociedade Religiosa abrange, em sentido amplo,

\footnotetext{
${ }^{42}$ Tomas de Aquino. Suma teológica. Madrid: Biblioteca de Autores Cristianos, 1960. 1-2,90,2c.3 ad 3.
} 
todos os grupos espirituais e, em sentido estrito, o Cristianismo (TOMAS DE AQUINO, 1960).

O Cristianismo para Pico é o ponto mais evoluído de uma tradição (aqui no sentido de entrega de conhecimento de geração a geração) religiosa, formada por um grande nexo seqüencial e evolutivo da Sociedade Religiosa. O reconhecimento dessas categorias por Pico demonstra o hibridismo do seu pensamento, no qual se conjugam uma filosofia da ação e uma atitude mística. Conforme explica Marcia Arruda Franco (2005, pp. 84-86), na descrição que faz do embate ideológico entre “armas e letras”, ilustrada pela lenda do Abade D. Juan de Montemor, intui-se que Sá de Miranda se aproxima da concepção piquiana de religião e poder temporal. Ele propõe que "Montemor-o-Velho será lembrado por suas Letras e não pelas guerras (santas)" (FRANCO, 2005, p. 86). O humanismo mirandino refuta a religiosidade ligada a qualquer espécie de justificação para uma determinada ordem sócio-política, e o ideal cruzado que gerou as guerras santas unia religião e política. Pina Martins (1991) é categórico quanto à proximidade entre Sá de Miranda e Giovanni Pico: "Podemos documentar na poesia de Sá de Miranda a existência de uma noção de dignidade, colhida exactamente no novo conceito do homem, definido no manifesto do Humanismo (o De hominis dignitate de Giovanni Pico della Mirandola)" (PINA MARTINS, 1991, p. 1031). Mas a verificação de que Sá de Miranda enalteceu especialmente as Letras evidencia uma aproximação filológica com Giovanni Pico. Como humanistas, consideram a linguagem, que é o veículo da Literatura, uma faculdade humana fundamental.

Unidade de pensamento e unidade da verdade imbricam-se inextricavelmente na filosofia piquiana. Sendo a verdade imutável e universal, ou seja, una, 
cada corrente de pensamento é uma aproximação da verdade, ou uma fração dela. Logo, a conciliação se impõe pela própria natureza da Filosofia. Cada fato da vida e do mundo encerra uma parte da Verdade. Ainda que, originalmente, a tese piquiana tenha servido primordialmente a uma tentativa de conciliação entre Platonismo e Aristotelismo, o grande cisma filosófico do Renascimento, vale para qualquer vertente filosófica até o momento presente.

A concórdia piquiana não significa uma união aleatória e amorfa de idéias antagônicas, mas o foro apropriado para testar a validade de qualquer idéia. A concórdia é principalmente diálogo, pois só é possível chegar à Verdade dialeticamente. A validade de uma tese não é dada a priori, e sim obtida a posteriori mediante a apresentação de um contraponto. Nas palavras do nosso filósofo:

A dialéctica acalmará a razão tumultuosamente mortificada entre os contrastes das palavras e dos silogismos capciosos. A filosofia natural acalmará os conflitos da opinião e os dissídios que atormentam, dividem e dilaceram de modos diversos a alma inquieta. ${ }^{43}$

Os que, de facto, seguem uma qualquer escola filosófica, de São Tomás, por exemplo, ou de Escoto, que actualmente congregam os maiores consensos, cimentam a sua doutrina na discussão de poucas questões. Eu, pelo contrário, propus interessar-me seriamente por todos os mestres da filosofia, examinar todas as posições, conhecer todas as escolas, mas não jurar sobre a palavra de ninguém. ${ }^{44}$

[...] em cada escola há algo de peculiarmente insigne não comum com as outras $[\ldots]^{45}$

Em virtude da possibilidade de ser tudo o homem é livre. Mas a liberdade de que trata Pico é orientada pela "recta razão". Logo, visa o bem. O que confere dignidade ao homem é a virtus. Afirmada nestes termos a dignidade do homem, a concórdia passa a ser uma conseqüência lógica, já que é o meio mais seguro para a

\footnotetext{
${ }^{43}$ Giovanni Pico Della Mirandola, op. cit., p. 69.

${ }^{44}$ Idem, p. 91.

45 Idem, p. 93.
} 
obtenção da Verdade. A concórdia implica paz. Isto posto, a filosofia piquiana vê a solidariedade fraternal como objetivo realizável.

A valorização da ação humana ressaltou o fato de ser o homem o criador da sua própria vida. No entanto, implantou-se uma dicotomia: elogio do homem criador das artes e ciências; menosprezo do homem que se entrega ao ócio improdutivo. Dentro desses dois extremos, o homem pode ser tudo, já que não tem nenhuma característica fixa. Neste ponto, o pensamento de Pico se aproxima do pensamento de Erasmo de Roterdam (1965, p. 74), que postula que só o homem goza do privilégio de aprender as artes e as ciências, a fim de suprir com os seus conhecimentos as lacunas da natureza. O homem é concebido como um microcosmos, que tem o dever de elevar-se e fundir-se ao macrocosmos absoluto, que é Deus. A discussão proposta por Giovanni Pico gira pelos três termos invariáveis do pensamento filosófico: Homem, Cosmos, Absoluto. Ou, em termos teológicos, Alma, Universo, Deus. Pico comprova a fungibilidade recíproca entre as duas formas de pensamento: filosófica e teológica.

Pico entende que a escolha com que o ser humano se depara na vida terrena deve ser a melhor possível, pois se baseia na reflexão racional. Essa escolha possibilitará a salvação eterna e a comunhão com Deus Pai. A escolha correta é a Verdade e a Salvação. Uma vez que a escolha é racional e o estudo da Filosofia dá o poder de escolher com "recta razão", Filosofia e Teologia tratam do mesmo assunto. Veja-se o que diz Pico: "Foi a filosofia que me ensinou a depender mais da minha consciência do que dos juízos dos outros; a estar sempre atento, não ao mal que de mim se diz, mas a não dizer ou 
a não fazer eu próprio o mal" ${ }^{\text {"46 }}$. Neste sentido, pensamento e ascensão ontológica estão intimamente relacionados, já que o homem bem versado em filosofia torna-se, segundo a nobre expressão de Horácio:

Fortis et in seipso totus teres atque rotundus,

Externi ne quid valeat per lœve morari;

In quem manca ruit semper Fortuna. ${ }^{47}$

O homem é livre e responsável pela vida que pretende ter e pela que já tem. Esta é uma obra sua; aquela, será. Coexistem no homem três naturezas: uma animal, uma divina e uma propriamente humana. Nessa perspectiva, agir é muito perigoso, já que a ação humana pode dirigir-se a duas direções diametralmente opostas: mundana e divina. A "recta razão", conseguida pelo estudo da Filosofia, leva o homem na direção ascendente, ou divina; e a ignorância leva o homem na direção descendente, ou mundana. Esta proposição também constitui uma aproximação com o pensamento de Erasmo de Roterdam (1965, p. 64), o qual postula que todas as coisas humanas têm dois aspectos. A natureza do homem é indefinida, mas, como é feito à imagem e semelhança de Deus, é natural que se realize de acordo com a sua essência divina. Como Filosofia e Teologia concorrem para a ascensão ontológica do ser humano, paz filosófica e paz teológica coincidem quando se está ao lado de Deus Pai.

Sá de Miranda percebeu os efeitos deletérios para o ser que é guiado por uma vontade cega, ou seja, não orientada pela "recta razão". O poeta filósofo identificou essa vontade com um inimigo interno. Veja-se o poema seguinte, número 10 da antologia mirandina do anexo:

\footnotetext{
${ }^{46}$ Idem, p. 85 .

${ }^{47}$ Firme, completo em si mesmo e inatingível; nele nenhum acontecimento exterior pode influir, sobre ele a Fortuna se arroja sempre em vão.
} Epístolas. Livro Primeiro 
Razão e tempo seria de ver sua vaidade aquela cega vontade, que tam cegamente guia.

Que poderá um grande imigo fazer mais? Certo é que não; por mimos do coração inda tudo o pior sigo. Vou-me assi de dia em dia, olhos de longe à verdade; entretanto, esta vontade, assi cega, guia, guia. ${ }^{48}$

O sujeito se vê irresistivelmente guiado por uma vontade que não obedece à Razão. Uma vez que é assim, a vontade passa a ser um inimigo. E um inimigo que está dentro, faz parte do eu. Pina Martins (1991) salienta que o humanismo mirandino, como o piquiano, define o homem como ser dotado de razão: "Em vários passos da sua obra insiste Sá de Miranda na definição do homem como ser que, em relação com os outros do reino animal, deles se distingue pelo entendimento. 'Nós temos entendimento', escreve, retomando uma comparação que, na tradição cultural européia, se repete de Dante a Erasmo" (PINA MARTINS, 1991, p. 1037). Mas a obra poética de Sá de Miranda deixa transparecer um sistema de pensamento próprio. De acordo com Jorge de Sena (2001, p. 59), ele é "um poeta especulativo, isto é, um homem em que a meditação social do concreto é indissolúvel da emoção lírica". Diversamente de Erasmo de Roterdam e Giovanni Pico Della Mirandola - que escreviam em Latim, língua universal do Humanismo -, Francisco de Sá de Miranda é um humanista lato sensu que, divulgando o Humanismo em língua vulgar, "fundamentava a dignidade das línguas vulgares, trilhando o caminho para a associação entre cultura, idioma e pátria como identificadores da nacionalidade" (FRANCO, 2005, p. 19).

\footnotetext{
${ }^{48}$ Francisco de Sá de Miranda, op. cit., p. 13
} 
A obra de Giovanni Pico Della Mirandola pode ser considerada como se fosse um "manifesto renascentista". O Discurso sobre a dignidade do homem é uma investigação profunda da alma humana realizada com um objetivo claro: conhecer a natureza humana. Não é uma mirada meramente eventual, mas deliberadamente crítica. A poesia quinhentista está impregnada da mentalidade descrita na Oratio e das apreensões derivadas dessa mentalidade. O tema do "inimigo de si" é, ao mesmo tempo, uma marca de modernidade - por configurar uma cisão subjetiva do eu lírico em virtude de um mergulho íntimo - e uma decorrência do espírito renascentista refletido na Lírica.

Assim como a obra de Pico, a lírica do "inimigo de si" constitui uma investida consciente na direção do eu. Segundo Hauser (1995), o fato novo introduzido pela Renascença foi a conversão do artista de observador da natureza em estudioso da natureza. Anteriormente, o naturalismo na arte era a manifestação casual de uma observação fortuita. Essa nova atitude artística e filosófica foi confundida com um ceticismo radical, o que não corresponde à verdade conforme o que se infere a partir da leitura da obra de Pico: o filósofo estuda e perscruta os meandros da natureza humana de acordo com a linha de pensamento que Costa Lima (2005, p. 57) chama de antropologia filosófica do Renascimento, mas o seu referencial é profundamente místico. O mesmo se pode afirmar em relação à lírica do "inimigo de si”, com todas as suas referências à alma. Como ensina Hauser (1995, p. 276):

As idéias sobre salvação, o outro mundo, redenção e pecado original, que encheram totalmente a vida espiritual do homem medievo, tornaram-se, é certo, meras "idéias secundárias", mas a ausência de todo sentimento religioso na Renascença não tem o menor fundamento. 
Outro equívoco no que se refere à Renascença é o seu caráter radicalmente individualista. De acordo com Hauser (1995), o suposto individualismo renascentista foi uma invenção do liberalismo pós-iluminista. A leitura atenta da obra piquiana corrobora o que propõe Hauser. Não há individualismo, nos termos em que este se apresentou ao mundo no século XIX. Os estudos de Giovanni Pico são sobre o homem enquanto gênero humano, suas pesquisas valem para qualquer um.

Associado ao individualismo radical, um sensualismo exacerbado costuma ser imputado ao Renascimento. Hauser (1995) refuta essa idéia categoricamente, como fruto dos recalques da classe média liberal, sufocada pela moral burguesa do século XIX. De fato, o corpus poético e a obra de Pico demonstram que a Renascença foi marcada muito mais pela pesquisa e pelo estudo do homem do que pela luxúria. Segundo Hauser (1995, p. 277),

O mal-estar com o mundo de moralidade classe-média e a revolta contra ela produziram o exuberante paganismo que tentou encontrar um substituto para prazeres fora do seu alcance descrevendo os excessos da Renascença. Nesse quadro, o condottiere, com sua demoníaca luxúria e desenfreada ânsia de poder, era a figura estereotipada do pecador irresistível, que cometeu, como que por procuração, todas as monstruosidades evocadas nos devaneios da classe média a respeito de uma vida feliz.

A lírica do "inimigo de si" é uma lírica de cisão do eu poético, em virtude de um fator interno e personalíssimo. Pressupõe um eu lírico totalmente voltado para si. Em virtude disso, os poemas do corpus que ilustram o tema estão marcados pela atitude lírica designada por Kayser (1967, p. 225) como liedhaftes Sprechen ou linguagem da canção. Esta é a atitude lírica por excelência, na qual objetividade e subjetividade se fundem no eu lírico para compor a expressão poética. 
O sujeito poético que se encontra em conflito íntimo e se vê a si mesmo como inimigo reflete o homem concebido pela doutrina piquiana. Giovanni Pico vê o ser humano como uma enorme gama de possibilidades entre dois extremos: a degradação total e a sublimação. Esta enaltece a condição humana e aquela a avilta. Ainda que sejam admitidos infinitos estágios no processo de evolução ou involução ontológica, o eu humano está irremediavelmente cindido em duas tendências antagônicas que coexistem. Como bem salientou Goethe, "somos a união de duas naturezas", daí o fatalismo de que está impregnado o tema do "inimigo de si”. Ele é um duplo real, como todo conteúdo lírico, uma vez que a Lírica é capaz de abarcar no eu qualquer faceta da realidade humana e expressá-la sob a forma poética.

Veja-se a seguinte cantiga de Sá de Miranda, que corresponde ao poema 8 da antologia mirandina do anexo:

Comigo me desavim, sou posto em todo perigo; não posso viver comigo nem posso fugir de mim.

Com dor, da gente fugia, antes que esta assi crecesse; agora já fugiria de mim, se de mim pudesse. Que meo espero ou que fim do vão trabalho que sigo, pois que trago a mim comigo, tamanho imigo de mim ? $^{49}$

O sujeito poético começa afirmando que está em perigo, pois se desentendeu consigo mesmo. A cisão está colocada claramente. Mas, como indicam o terceiro e quarto versos, a desagregação do ser - com a conseqüente incompatibilidade de si

\footnotetext{
${ }^{49}$ Francisco de Sá de Miranda, op. cit., pp. 9 e 10.
} 
consigo mesmo - é ainda mais dolorosa por ser irremediável, já que a reconciliação também é impossível. O sujeito poético termina manifestando sua desesperança no futuro. Afinal, de nada vale viver e trabalhar se não há como fugir da tortura interior e desfrutar da vida. Antes, o sujeito via no outro o perigo e o inimigo potencial. Agora, após a revelação terrível, tenta fugir de si, mas constata que isso é impossível. O sujeito encontra-se diante de um impasse: não pode fugir nem ficar em si. Não sabe como solucionar o conflito, mas entrevê um desfecho infeliz.

Bernardim Ribeiro também aborda o tema. Veja-se a trova "Que forte fortuna sigo", de sua autoria, correspondente ao poema 1 da antologia bernardiniana do anexo:

Que forte fortuna sigo,
a que grande extremo vim,
que já não vejo perigo
para mim maior que mim!
Tudo soube recear
que era bem que receasse;
quem havia de cuidar
que de mim eu me guardasse?
Não me guardei como devo,
e vim ter a o que vim,
que já não vejo perigo
para mim maior que mim.

O sujeito poético está espantado com o fato de encontrar o inimigo dentro de si mesmo, o que já é indicado na primeira estrofe pelo ponto de exclamação e pelo tom do discurso. Os quatro primeiros versos da segunda estrofe mostram que o sujeito não esperava descobrir-se como “inimigo de si”, pois não lhe parece razoável prevenir-se contra si mesmo. Mas, nos quatro versos seguintes, penitencia-se de não ter previsto que o

\footnotetext{
${ }^{50}$ Bernardim Ribeiro, op. cit., pp. 172 e 173.
} 
inimigo estava tão próximo, não o ter enxergado apesar da sua proximidade, e não ter tomado as devidas precauções.

A seguinte trova, correspondente ao poema de número 4 da antologia bernardiniana do anexo, tem início muito mais dramático que o poema de Sá de Miranda. Este começa com o pronome pessoal do caso oblíquo "comigo" o qual tem uma carga semântica de união, ao passo que o de Bernardim Ribeiro começa com a preposição "entre", a qual tem uma carga semântica de separação, de vazio entre duas coisas. A primeira estrofe tem o teor de uma auto-indagação, o sujeito poético não sabe em que consiste o vazio, o que há nele. Fernando Pessoa recepcionará Bernardim Ribeiro respondendo: "Sou entre mim e mim o intervalo -" "51. O intervalo, que é a mais palpável materialização do vazio.

$\mathrm{Na}$ segunda estrofe, verifica-se o que se convencionou chamar "trajeto do engano ao desengano": o sujeito vive bem e com certa felicidade, porém enganado; e, quando se dá conta da realidade, percebe que tem motivos para sofrer e passa a padecer as dores desse sofrimento. Antes da revelação espantosa do poema anterior, o sujeito vivia enganado, sem imaginar que o inimigo estava dentro e sem se precaver. Tal engano custou caro. Ao evocar o presente eterno da Lírica, o último verso não dá margem para nenhuma esperança por parte do sujeito poético, o qual está condenado a viver num conflito interior perpétuo.

Entre mim mesmo e mim não sei que se levantou, que tam meu imigo sou.

\footnotetext{
51 Fernando Pessoa. Obras completas de Fernando Pessoa vol. VII - poesias inéditas (1930-1935) de Fernando Pessoa. Lisboa: Edições Ática, 1955. p. 93.
} 
Uns tempos com grande engano

vivi eu mesmo comigo;

agora no maior perigo

se me descobriu mor dano.

Caro custa um desengano,

e, pois me êste matou,

assás caro me custou.

De mim sou feito alheio; entre cuidado e cuidado, está um mal derramado, que por meu gram mal me veio; nova dor, novo receio, foi êste que me tomou, que tam meu imigo sou. ${ }^{52}$

Na Fábula do Mondego, conforme nota Marcia Arruda Franco (2005, p. 89), "Diego demonstra um tipo de loucura que, ao dilacerar o sujeito, lembra o tópico do 'inimigo de si'”:

Ívase Diego ansí devaneando por sus locuras, que cabo no tienen, unos y otros cansancios sin provecho, los unos idos, los otros que vienen, consigo de contino peleando, va batalha cruel dentro en su pecho. ${ }^{53}$

O poema seguinte, de Luis de Camões e de número 2 da antologia camoniana do anexo, discrepa levemente dos anteriores. Não no que se refere à cisão do eu, mas no tom fatalista deles. Apesar de reconhecer o drama da fragmentação do próprio eu a que está submetido e o fato de que para isto não há remédio, Camões encara o problema com certa naturalidade e consegue ver até mesmo o seu lado interessante. O sujeito poético tem plena consciência de que o conflito interior é inerente a qualquer personalidade: ele se convenceu de que, uma vez que se está vivo, não se pode ser feliz, pois não há como se livrar do inimigo interno. No entanto, para ele, é justamente essa tensão perene que dá

\footnotetext{
${ }_{52}^{52}$ Bernardim Ribeiro, op. cit., pp. 185 e 186.

${ }^{53}$ Francisco de Sá de Miranda, op. cit., p. 84.
} 
emoção à vida. Na visão do poeta, o conflito interior é principalmente desafiador, no melhor sentido da palavra.

\section{MOTE}

De que me serve fugir

de morte, dor e perigo,

se me eu levo comigo?

\section{VOLTAS}

Tenho-me persuadido, por razão conveniente, que não posso ser contente, pois que pude ser nacido. Anda sempre tão unido o meu tormento comigo que eu mesmo sou meu perigo.

E se de mi me livrasse, nenhum gosto me seria; que, não sendo eu, não teria mal que esse bem me tirasse. Força é logo que assi passe: ou com desgosto comigo, ou sem gosto e sem perigo. ${ }^{54}$

O mote do poema dá a entender que a fonte da "morte, dor e perigo" é o próprio eu. A primeira volta retoma a idéia do mote: de fato, não é possível existir algo mais unido ao sujeito do que ele mesmo (três últimos versos da volta). De acordo com o terceiro e quarto versos da volta, não há escapatória para a infelicidade, pois basta nascer para ser infeliz. A segunda volta corrobora a anterior e o mote. Livrar-se desse inimigo (si próprio) não constitui alegria, pois o "bem” de não ser si mesmo é um bem inócuo. Logo, não é bem. Portanto, ter permanentemente um inimigo junto de si é um desgosto, mas é também algo que dá estímulo, por ser um desafio. $O$ desafio de vencer a si próprio

\footnotetext{
${ }^{54}$ Luís de Camões. Lírica completa - volume I. Prefácio e notas de Maria de Lurdes Saraiva. Lisboa: Imprensa Nacional - Casa da Moeda, 1980. p. 35.
} 
diariamente. Quando se perde o perigo, perde-se o estímulo. Além disso, eliminar o mal implica eliminar-se a si mesmo.

O poema "Muito sou meu inimigo" ( $n^{\circ} 7$ da antologia camoniana do anexo) também trata o "inimigo de si" como um duplo natural e inerente à condição humana. O mote que o Viso-Rei mandou a Camões apresenta um sujeito poético que é inimigo de si mesmo porque não elimina o que lhe põe a vida em risco (os cuidados). A primeira volta de Camões corrobora, nos cinco últimos versos, o mote proposto. Mas deixa patente a visão do sujeito poético acerca da existência do duplo como "inimigo de si". Os três primeiros versos afirmam a inevitabilidade dos "cuidados". Os dois versos seguintes conferem um dúplice aspecto aos "cuidados": é peçonha, logo, é mau; mas é parte integrante do ser, logo, é inócuo. A segunda volta suscita como única possibilidade de conciliação íntima o fim da existência, dando fim a si e aos "cuidados". "Pôr a vida em perigo" é uma via de solução.

A problemática do "inimigo de si” tem seu grande precedente literário no poeta espanhol, Don Jorge Manrique. Isso significa que o ciclo temático do "inimigo de si" inscreve-se na poesia luso-castelhana (FRANCO, 2005, p. 93), uma vez que os poetas herdam o tema do poeta espanhol e Sá de Miranda glosa sua cantiga "No sé por qué me fatigo", o poema 19 das Coplas a la muerte de su padre:

No sé por qué me fatigo, pues con razón me vencí, no siendo nadie conmigo y vos y yo contra mí.

Vos por m'haber desamado, yo por haberos querido, con vuestra fuerça y mi grado habemos a mí vencido; 
pues yo fui mi enemigo

en darme como me dí,

¿quién osará ser amigo

del enemigo de sí? ${ }^{55}$

O poema é aproximadamente meio século mais antigo que os anteriores.

Note-se que, diferentemente dos portugueses, este poema espanhol apresenta uma causa externa de fragmentação do eu lírico: o objeto amado. A primeira estrofe apresenta o sujeito sozinho em um combate travado entre ele mesmo e o objeto do amor ao qual se alia o seu inimigo interior. Essa aliança se dá em virtude do amor que o sujeito sente e que é retribuído com desprezo. O sujeito está dividido em dois: um que ama; e outro que tenta resistir inutilmente aos impulsos do amor. A vitória é da aliança entre a parte que ama e o objeto amado sobre a parte que tenta resistir. O poeta termina o poema lançando um desafio e perguntando: quem ousará ser amigo do próprio inimigo?

Don Jorge Manrique suscitou uma posteridade literária e tanto. Foram seus epígonos Sá de Miranda, Bernardim Ribeiro, Camões, Pessoa, Maria Teresa Horta e os que desenvolveram liricamente o "inimigo de si". O poema apresenta dois eus: um consigo mesmo e outro aliado da "amada inimiga". Cria-se o sistema: amada + eu x eu. A amada e uma das facetas do eu em contubérnio contra a outra faceta do eu. Para que a vitória da "amada inimiga" e do "eu inimigo" sobre o eu original pudesse ter ocorrido, dois fatos concorreram: o eu amar e a amada desamar. Aqui tem-se a explicação da cisão em "inimigo de si" na origem. O eu cindiu-se e tornou-se inimigo de si ao amar e dar-se em ascese amorosa. Aqui, ela deixa de ser positiva e purificadora como na lírica medieval. Mas, de qualquer maneira, o elemento desagregador do eu ainda é externo. Logo, a precedência da literatura portuguesa na cisão íntima do eu lírico por fatores internos e

\footnotetext{
${ }^{55}$ Jorge Manrique. Coplas a la muerte de su padre. Madrid: Editorial ALBA, 1999. p. 73.
} 
personalíssimos se mantém. Entretanto, não resta dúvida que os poetas quinhentistas portugueses leram e foram influenciados por Manrique. Sá de Miranda glosou o poema de Manrique (poema 2 da antologia mirandina do anexo), o que demonstra admiração pela temática e virtuosismo do poeta luso ao glosar os 12 versos desta cantiga. Como Sá de Miranda está glosando um modelo alheio, o seu poema segue o mesmo raciocínio do poema mote, apenas seu conteúdo temático é muito mais desenvolvido.

Sá de Miranda, apesar da influência de Jorge Manrique quanto ao tema eminentemente filosófico do "inimigo de si", é um inovador da lírica. Conforme explica Pina Martins (1991, p. 1030), “enquanto as éclogas de Sannazaro são formas poéticas estruturalmente bucólico-líricas, as de Sá de Miranda podem caracterizar-se como líricofilosóficas, visto que os pastores são puras personagens de disfarce”. O bucolismo, em Sá de Miranda, transforma-se em um diálogo do homem com o homem. Os pastores debatem questões existenciais.

Marcia Arruda Franco (2001), ao analisar a recepção crítica novecentista da obra mirandina, aponta entendimentos no sentido de que a écloga, enquanto poesia dramática, implica cisão do eu poético em vários entes (os pastores). É, portanto, poesia do eu cindido e se inscreve no ciclo temático do "inimigo de si". Os pastores mirandinos, diferentemente dos camonianos, são inimigos de si, vivem em conflito consigo mesmos. $\mathrm{O}$ autor dessa tese é David Mourão-Ferreira, para quem o processo de cisão na écloga é análogo ao da heteronímia pessoana. Como explica Marcia Arruda Franco (2001, p. 38), “para David Mourão Ferreira, um mesmo processo criativo preside a construção heteronímica e a dos pastores do discurso bucólico". O estudioso chega ainda mais longe, ao dizer que Fernando Pessoa é: 
“"o acabado representante desta atitude poética despersonalizante e parateatral, que, subsidiária da atitude bucólica, entrou no lirismo português através de Sá de Miranda'. O crítico português chega a 'encarar o conjunto da obra de Fernando Pessoa como um novo tipo eclogal, em que os heterónimos mantêm perante o seu criador as mesmas relações paradoxais dos pastores perante o poeta bucólico: relações aparentemente contraditórias, independentes ou dispersivas - mas, afinal, e em última análise, definidoras, por um processo dialético, de uma cíclica e complexa unidade" ${ }^{, 56}$.

A Razão humana, conforme se viu, é tema caro a Giovanni Pico Della

Mirandola e a Sá de Miranda. Veja-se agora o seguinte soneto de Camões, que corresponde ao poema 22 da antologia camoniana do anexo:

Sempre a Razão vencida foi de Amor; mas, porque assi o pedia o coração, quis Amor ser vencido da Razão. Ora que caso pode haver maior!

Novo modo de morte e nova dor! Estranheza de grande admiração: que perde suas forças a afeição, por que não perca a pena o seu rigor.

Pois nunca houve fraqueza no querer, mas antes muito mais se esforça assim um contrário com outro, por vencer.

Mas a Razão, que a luta vence, enfim, não creio que é razão; mas há-de ser inclinação que eu tenho contra mim. ${ }^{57}$

Há uma pista textual do "inimigo de si" no último verso do soneto. No entanto, o poema se desenvolve sobre um suposto antagonismo entre Razão e Amor. A razão que mata o sentimento fonte de sofrimento também mata a vivência do belo. Logo, não é totalmente positiva. Antes é mesquinha, pois mata o belo por motivos egoístas. Se o Amor é ascese, ele compensa o sofrimento com a purificação da alma. Por isso, o sujeito

\footnotetext{
${ }^{56}$ David Mourão Ferreira (apud FRANCO, 2001, p.38).

${ }^{57}$ Luís de Camões. Lírica completa - volume II. Prefácio e notas de Maria de Lurdes Saraiva. Lisboa: Imprensa Nacional - Casa da Moeda, 1980. p. 206.
} 
poético vê essa pretensa razão como uma inclinação que tem contra si. De temática análoga é o soneto "Desarrezoado amor, dentro em meu peito", de Sá de Miranda (correspondente ao poema 32 da antologia mirandina do anexo). Camões trata do mesmo conflito no poema "No meu peito o meu desejo" ( $n^{\circ} 18$ da antologia camoniana do anexo). Porém neste o resultado é uma vitória do desejo.

Marcia Arruda Franco (2001) sintetiza a questão de maneira bastante clara e precisa: "No século XVI, o tema do 'imigo de si' fez parte da redescoberta renascentista da subjetividade. Deslizando da lírica amatória para a reflexiva, o tema indicia, entre os poetas quinhentistas que o glosaram, o caráter sui generis do sujeito poético português como o que conhece a loucura de não gostar de si mesmo" (FRANCO, 2001, p. 115). 


\section{A recepção da cisão subjetiva na lírica portuguesa pós-simbolista}

O falar de si é uma atitude recorrente do eu lírico modernista, a qual foi inaugurada por Baudelaire, conforme ensina Hugo Friedrich (1991, p. 37): "Quase todas as poesias de Les Fleus du Mal falam a partir do eu. Baudelaire é um homem completamente curvado sobre si mesmo. Todavia este homem voltado para si mesmo, quando compõe poesias, mal olha para seu eu empírico". Logo, o eu cidadão - ou seja, biográfico, real fruto da experiência social está excluído do âmbito do mergulho íntimo da literatura intimista.

A noção de ser - tão profundamente estudada por filósofos como Jean Paul Sartre e Martin Heidegger - é de importância fundamental para a Modernidade, e é apreendida por meio de uma constatação terrível: a de que o ser pode fragmentar-se. Hugo Friedrich frisa que "com Baudelaire começa a despersonalização da lírica moderna" (1991, p. 36). Arthur Rimbaud sintetiza o problema na sua famosa formulação "je est un autre". Em carta de 15 de maio de 1871, enviada ao poeta Paul Demeny, conhecida como a "Carta do Vidente", Rimbaud estabelece um projeto literário para uma lírica que perscruta os meandros desconhecidos do eu, encarando a cisão como coisa natural. Assim diz Rimbaud:

Porque Eu é um outro. Se o cobre acorda clarim, nenhuma culpa the cabe. Para mim é evidente: assisto à eclosão do pensamento, eu a contemplo e escuto. Tiro uma nota ao violino: a sinfonia agita-se nas profundezas ou ganha de um salto a cena. Se os velhos imbecis tivessem descoberto algo mais que a falsa significação do $\mathrm{Eu}$, não teríamos de varrer os milhões de esqueletos que, desde um tempo infinito, vêm acumulando os produtos de sua inteligência caolha, arvorados em autores! $!^{58}$

\footnotetext{
${ }^{58}$ Arthur Rimbaud. Poesia completa; Edição bilíngüe, português e francês. Tradução, prefácio e notas de Ivo Barroso. Rio de Janeiro: Topbooks, 1995. pp. 16 e 17.
} 
A transferência do elemento transtornador e angustiante do mundo exterior para o interior segue o fenômeno da inversão do processo de inspiração poética lançado pelo Simbolismo, sobretudo por Baudelaire. Ao associar um fenômeno do mundo exterior a um estado de espírito, o eu lírico caminha do fenômeno à representação poética. Com o advento de Flores do mal e do Simbolismo, o eu lírico simplesmente deixou de se inspirar no mundo para inspirar-se em si mesmo. Segue o caminho de si mesmo à expressão poética. O eu lírico passou a falar de si e a Lírica se tornou profundamente intimista, pois o centro da poesia simbolista é o eu lírico. Daí as imagens e os lugares que propiciam o mergulho íntimo.

O Simbolismo conferiu à poesia lírica o máximo potencial expressivo da sua capacidade intrinsecamente simbólica, enquanto discurso autônomo, que veicula seu conteúdo unicamente pela palavra. Inspiração e expressão consubstanciam-se. Eu e não-eu reúnem-se, e entram em conflito. O fim do fenômeno do mundo como elemento inspirador externo gerou a tensão que cindiu o eu lírico. Aquele servia como fator de cotejo para o eu lírico, uma válvula de escape para suas angústias. Agora o eu está só com elas. Além disso, em sede de poesia, o mundo está no eu lírico muito mais do que este está no mundo. Ao partir de si mesmo no processo de inspiração poética, o poeta abre mão de ver a si no mundo para ver o mundo em si. E o peso do mundo é uma carga difícil de suportar.

A ontologia fenomenológica de Jean-Paul Sartre analisa o imaginário diferenciando pensamento de imagem: aquele é um ato da consciência que atribui uma qualidade ou característica a um objeto; esta é um ato da consciência que produz seu próprio objeto. Logo, o pensamento parte do objeto para a consciência e a imagem é criada na consciência. Uma vez que o mundo está no eu lírico, na poesia, a imaginação suprime o 
pensamento para forjar a expressão poética, para criar o mundo. Eis a responsabilidade da Lírica: o Gênero Épico conta, é o pensamento em ação na produção literária, vai do objeto à consciência, reflete o mundo como um espelho (na feliz alegoria de Stendhal) para depois expressá-lo na obra literária; a Lírica contém o mundo, sintetiza-o no seu momento ao mesmo tempo instantâneo e eterno. A consciência lírica cria seu próprio objeto que é o mundo.

A postura lírica da Escola Simbolista fez epígonos em todas as literaturas, com grande destaque para os portugueses. Entretanto, antes da generalização dessa nova postura lírica encetada pelo Simbolismo e por Baudelaire, a poesia portuguesa já contava com notáveis exemplos da poética que tem no eu o seu elemento fundamental, o grande centro de irradiação lírica. $O$ que chama a atenção nessa precedência portuguesa é o incrível lapso temporal que a separa de Baudelaire: 300 anos. O Quinhentismo literário português apresenta traços de modernidade patentes em poemas dos seus maiores autores ainda que tais traços inscrevam-se no contexto estético e filosófico da época: a grande revolução antropocêntrica do Renascimento. Esses traços são facilmente verificáveis pelo cotejo com poemas desses mesmos autores nos quais a Lírica não se desenvolve mediante a introversão. Quando o objeto da Lírica é externo, a mulher amada, o eu não se cinde. Disso conclui-se que o amor é uma espécie de refúgio do eu lírico, já que o amor tem o poder de libertar o Ser do mergulho íntimo, quando este se afigura como prisão íntima. Sair de si mesmo é condição inicial para amar, e mais ainda, reconhecer a própria insuficiência para buscar fora de si o que falta dentro. Sobre os poemas em que o eu lírico não buscou o refúgio do amor incide a ancestralidade e a precedência da cisão íntima do eu lírico moderno, o qual recepciona esta temática, cujo exemplo notável é o "inimigo de si”. 
Hugo Friedrich consegue entrever, na poética de Baudelaire, traços característicos que possuem grande afinidade temática com o "inimigo de si". Para o estudioso, "hiperbólico" é uma palavra-chave para entender a natureza humana na lírica do poeta francês: “o homem é 'hiperbólico', sempre propenso para o alto, numa febre espiritual. Mas é um homem essencialmente cindido, homo duplex, tem de satisfazer seu poder satânico, para ir ao encalço do celestial" (FRIEDRICH, 1991, p. 46). Note-se que o elemento satânico não é refutado pela busca do celestial. Bem e mal caminham de braços dados. Logo em seguida, Hugo Friedrich esclarece que “a meta da ascensão não só está distante, como vazia, uma idealidade sem conteúdo. Esta é um simples pólo de tensão, hiperbolicamente ambicionado, mas jamais atingido" (FRIEDRICH, 1991, p. 48). Como a ascensão ao plano da idealidade é impossível, engendra uma cisão entre aquela faceta do eu que tem esperança de atingi-la e aquela já consciente de que não poderá fazê-lo.

À tendência natural da literatura portuguesa para ocupar-se deste assunto soma-se a força revolucionária da grande renovação da poesia lírica ocorrida após o Simbolismo. Observe-se o poema "7" de Mário de Sá-Carneiro. A fragmentação do eu é dramática. O sujeito poético perdeu-se na busca do outro. Ficou na metade do caminho entre o que era e o que aspirava a ser. A ponte já seria "qualquer coisa de intermédio", mas chegaria ao Outro; o sujeito poético, não. Este é apenas o pilar: paralisado, imóvel.

Eu não sou eu nem sou o outro, Sou qualquer coisa de intermédio:

Pilar da ponte de tédio

Que vai de mim para o Outro. ${ }^{59}$

\footnotetext{
${ }^{59}$ Mário de Sá-Carneiro. Obras completas de Mário de Sá-Carneiro Volume II - Poesias. Lisboa: Edições Ática, 1978. p. 94.
} 
Mário de Sá-Carneiro é um poeta da subjetividade. Seus poemas representam estados, modos, gestos, metáforas do eu. Tome-se o seguinte poema:

\section{COMO EU NÃO POSSUO}

Olho em volta de mim. Todos possuem Um afecto, um sorriso ou um abraço.

Só para mim as ânsias se diluem E não possuo mesmo quando enlaço.

Roça por mim, em longe, a teoria Dos espasmos golfados ruivamente; São êxtases da cor que eu fremiria, Mas a minh'alma pára e não os sente!

Quero sentir. Não sei... perco-me todo... Não posso afeiçoar-me nem ser eu:

Falta-me egoísmo para ascender ao céu, Falta-me unção para me afundar no lodo.

Não sou amigo de ninguém. Para o ser Forçoso me era antes possuir Quem eu estimasse - ou homem ou mulher, E eu não logro nunca possuir!...

Castrado de alma e sem saber fixar-me, Tarde a tarde na minha dor me afundo... Serei um emigrado doutro mundo Que nem na minha dor posso encontrar-me?

Como eu desejo a que ali vai na rua, Tão ágil, tão agreste, tão de amor... Como eu quisera emaranhá-la nua, Bebê-la em espasmos de harmonia e cor!...

Desejo errado... Se a tivera um dia, Toda sem véus, a carne estilizada Sob o meu corpo arfando transbordada, Nem mesmo assim - ó ânsia! - eu a teria...

Eu vibraria só agonizante Sobre o seu corpo de êxtases doirados, Se fosse aqueles seios transtornados, Se fosse aquele sexo aglutinante...

De embate ao meu amor todo me ruo, E vejo-me em destroço até vencendo: 
É que eu teria só, sentindo e sendo

Aquilo que estrebucho e não possuo. ${ }^{60}$

O não possuir é dado como condição do eu. Isto se evidencia no título “Como eu não possuo", que é uma oração subordinada adverbial causal de uma oração principal que está elíptica. A interrupção abrupta do período composto por subordinação leva imediatamente o leitor ao texto do poema, ao longo do qual a ruptura sintática do título, mais do que se esclarecer, ganha significado. A diluição da identidade do eu se dá em virtude da idéia de não possuir. Logo, o elemento externo é fator de identidade e unidade do eu; e a sua não-posse, fator de desagregação. Como na dilaceração do eu lírico dos poemas quinhentistas pela negativa da amada.

O esquema rímico, como elemento estético da forma, corrobora e ilustra o conteúdo. O poema alterna rimas cruzadas e interpoladas. Estas aparecem na $3^{\mathrm{a}}, 5^{\mathrm{a}}, 7^{\mathrm{a}}, 8^{\mathrm{a}}$ e $9^{a}$ quadras, as quais apresentam de maneira mais terrível a solidão do eu. As rimas interpoladas das referidas quadras simulam um abraço que o primeiro e quarto versos dão no segundo e terceiro, o abraço reclamado desesperadamente pelo sujeito poético no segundo verso da primeira quadra. A imagem do abraço aparece também na rima idêntica entre o título ("Como eu não possuo") e o último verso ("Aquilo que estrebucho e não possuo"), promovida pelo verbo "possuir" conjugado na primeira pessoa do singular do presente do indicativo. O verbo "possuir" desponta ainda, carregado de ironia, na quarta quadra, promovendo a única rima idêntica no corpo do poema, por aparecer na forma nominal do infinitivo. A ironia reside no fato de a rima ser idêntica apenas quanto ao aspecto sonoro. No plano semântico, os versos rimados têm sentidos diametralmente

\footnotetext{
${ }^{60}$ Mário de Sá-Carneiro. Obras completas de Mário de Sá-Carneiro Volume II - Poesias. Lisboa: Edições Ática, 1978. pp. 70-72.
} 
opostos: "Forçoso me era antes possuir" tem carga semântica afirmativa; e "E eu não logro nunca possuir!...” tem carga semântica negativa. Em uma notável demonstração de como a forma pode corroborar e ilustrar o conteúdo, esses dois versos unidos pela rima sintetizam a idéia central do poema: possuir um objeto vivo de estima é um fator de identidade e unidade do eu poético; e não o possuir é causa de dispersão e cisão, o que efetivamente ocorre e fica patente na quinta quadra pelos sintagmas "fixar-me" e "encontrar-me", onde a forma acidentalmente pronominal confere carga semântica reflexiva aos verbos.

Em Fernando Pessoa, a separação, a cisão, o conflito e o antagonismo se radicalizam e exasperam de tal forma que geram heterônimos. De acordo com essa linha de raciocínio, a heteronímia pessoana é vista como criação poética para expressar essa questão que remonta ao século XVI: a fragmentação do eu lírico. Para demonstrar que o interesse por este assunto pré-existe em Fernando Pessoa independentemente da heteronímia, vejamse os poemas I e III de Chuva Oblíqua de Fernando Pessoa ortônimo:

\section{I}

Atravessa esta paysagem o meu sonho d'um porto infinito

E a côr das flôres é transparente de as velas de grandes navios

Que largam do caes arrastando nas aguas por sombra

Os vultos do sol d'aquellas arvores antigas...

O porto que sonho é sombrio e pallido

E esta paysagem é cheia de sol d'este lado...

Mas no meu espirito o sol d'este dia é porto sombrio

E os navios que sahem do porto são estas arvores ao sol...

Liberto em duplo, abandonei-me da paysagem abaixo...

$\mathrm{O}$ vulto do caes é a estrada nitida e calma

Que se levanta e se ergue como um muro,

E os navios passam por dentro dos troncos das arvores

Com uma horizontalidade vertical,

E deixam cahir amarras na agua pelas folhas uma a uma dentro... 
Não sei quem me sonho...

Súbito toda a agua do mar do porto é transparente

E vejo no fundo, como uma estampa enorme que lá estivesse desdobrada,

Esta paysagem toda, renque de arvores, estrada a arder em aquelle porto,

E a sombra d'uma náu mais antiga que o porto que passa

Entre o meu sonho do porto e o meu vêr esta paysagem

E chega ao pé de mim, e entra por mim dentro,

E passa para o outro lado da minha alma... ${ }^{61}$

\section{III}

A Grande Esphynge do Egypto sonha por este papel dentro...

Escrevo - e ella apparece me atravez da minha mão transparente

E ao canto do papel erguem-se as pyramides...

Escrevo - perturbo-me de vêr o bico da minha penna

Ser o perfil do rei Cheops...

De repente paro...

Escureceu tudo... Caio por um abysmo feito de tempo...

Estou soterrado sob as pyramides a escrever versos á luz clara d'este candieiro

E todo o Egypto me esmaga de alto atravez dos traços que faço com a penna...

Ouço a Esphynge rir por dentro

O som da minha penna a correr no papel...

Atravessa o eu não poder vel-a uma mão enorme,

Varre tudo para o canto do tecto que fica por detraz de mim,

E sobre o papel onde escrevo, entre elle e a penna que escreve

Jaz o cadaver do rei Cheops, olhando me com olhos muito abertos,

E entre os nossos olhares que se cruzam corre o Nilo

E uma alegria de barcos embandeirados erra

Numa diagonal diffusa

Entre mim e o que eu penso...

Funeraes do rei Cheops em ouro velho e Mim!... ${ }^{62}$

Ambos os poemas são expressões notáveis da estética denominada

Interseccionismo ao buscar o ponto de encontro lógico entre o emotivo e o intelectual - no plano do eu - e entre as várias dimensões físicas da matéria - no plano do mundo cognoscível. Tal ponto seria o sonho: os dois poemas descrevem seqüências de fenômenos psíquicos (imagens, representações, atos, idéias, etc.) inconcebíveis fora desse estado

\footnotetext{
${ }^{61}$ ORPHEU. Números 1 \& 2. Provas de página do terceiro número. Edição facsimilada. $2^{\mathrm{a}}$ ed., Lisboa, Contexto, 1994. p. 161.

${ }^{62}$ Idem. P. 162.
} 
mental. O título "Chuva oblíqua" já suscita a intersecção de duas dimensões: a verticalidade, representada apela chuva, que em sua queda esboça uma trajetória vertical; e a obliqüidade, representada pelo caráter atribuído à chuva pelo adjetivo "oblíqua".

Quanto ao plano do eu, é no sonho que surge a capacidade de "outrarse", de dividir ou duplicar o próprio eu, como sugere o verso 9 do poema I: "Liberto em duplo, abandonei-me na paysagem abaixo...". O pronome pessoal do caso oblíquo de primeira pessoa do singular "me" na função de objeto direto e o verbo conjugado na primeira pessoa do singular reforçam essa idéia, já que implicam necessariamente na coincidência entre os dois, pois essas duas palavras se referem à mesma pessoa do discurso. O sujeito (no caso, oculto) que abandona e o objeto abandonado são o mesmo ente: o eu, porém duplicado. O sonho também passa a ser um momento de liberdade, pois ao desdobrar-se - o que só é possível no sonho - o eu torna-se "liberto".

O verso 15, "Não sei quem me sonho...", apresenta outro caso interessante de desdobramento do eu no plano do sonho. A frase que compõe o verso é um período composto por subordinação no qual há a oração principal (Não sei) e a oração subordinada substantiva objetiva direta (quem me sonho). Existem três componentes da frase que se referem à mesma pessoa do discurso: o sujeito oculto (eu); o pronome indefinido (quem); e o pronome reflexivo (me), já que o verbo "sonhar" é empregado na sua forma acidentalmente pronominal. $\mathrm{O}$ eu poético se desdobra em três: o que sonha (sujeito oculto); o que é objeto do sonho (me); e o que este se torna no sonho (quem).

Em sua criação artística, o poeta logra demonstrar o que ocorre ao eu e ao mundo no sonho. A arte moderna - ao ocupar-se da questão do eu e sua relação com o 
mundo - caminha paralelamente à psicanálise freudiana ${ }^{63}$ porque, para a ciência psicanalítica, tudo o que aparece no sonho decorre da vivência do eu no mundo. Aliás, sonho e poesia são quadros de significação a posteriori. Sonhos e poemas estão sempre sujeitos à analise. Mas enquanto no sonho há apenas um rudimento de realidade, pontos de referência da vida real que o sonho deriva para a vida imaginária, no poema lírico há uma referência de sentido universal.

No plano do mundo cognoscível, o ponto de encontro (ou de intersecção) é a perda da lógica, representada pelo oximoro "horizontalidade vertical" (verso 13); e a intersecção propriamente dita, representada pela impossibilidade física de a matéria ocupar o mesmo lugar no espaço: "E os navios passam por dentro dos troncos das árvores" (verso 12). Entretanto, no final da última estrofe, a intersecção adquire um certo teor de possibilidade pela natureza das coisas que se interseccionam. A "náu mais antiga que o porto que passa entre o meu sonho do porto e o meu vêr esta paysagem" (versos 19/20) entra no sujeito poético, mas não no sentido de atravessar-lhe o corpo e sim de atingir sua alma. Esta bela imagem é produzida pela gradação "E chega ao pé de mim, e entra por mim dentro, e passa para o outro lado da minha alma" (versos 21/22) e pelo polissíndeto na repetição da conjunção coordenativa "e". A intersecção torna-se possível por ser a alma incorpórea e a nau um símbolo do passado glorioso de Portugal - ou seja, também incorpóreo -, o qual viverá eternamente na alma do sujeito poético.

\footnotetext{
${ }^{63}$ As normas de Freud para a interpretação dos sonhos. Alexander Grinstein. Tradução de Francisco M. da Rocha Filho. Rio de Janeiro: Imago, 1987.
} 
Neste ponto da análise, surgem elementos históricos fundamentais para a interpretação do poema: as grandes navegações portuguesas do fim do século XV e o estado de decadência em que se encontrava Portugal no início do século XX.

O verso 5, "O porto que sonho é sombrio e pallido", diz como é o porto do sonho: sombrio e pálido. E o verso 19, “E a sombra d'uma náu mais antiga que o porto que passa", diz que a nau que vai alojar-se no outro lado da alma é mais antiga que o porto do sonho. O sujeito poético vê essa nau antiga como um ponto arcaico que conduz à recuperação da memória coletiva portuguesa: as grandes navegações. Logo, incompatível com um porto sombrio e pálido, o qual representa a decadência atual. A velha nau que guarda toda a glória portuguesa é algo que merece ser guardado na alma - a qual passa a representar a história coletiva portuguesa simbolizada por uma alma coletiva - e é o que de fato acontece porque essa nau "passa entre o meu sonho do porto e o meu vêr esta paysagem", ou seja, passa incólume por esse lugar sombrio para penetrar na alma.

No seu lançar de olhos ao passado, Fernando Pessoa encontra Sá de Miranda, lançando os olhos ao futuro. A exegese mirandina do momento histórico português que conheceu contempla dois aspectos: o legado do Humanismo que aponta para a Modernidade e a decadência que se aproxima do Império Português (PINA MARTINS, 1991, p. 1036). Os fatos corroboram essa situação dúbia: por um lado, Portugal foi a vanguarda da expansão marítima européia; e por outro, ainda era um país de economia agrária, em contraste com outros países europeus. Sá de Miranda, “mesmo reconhecendo o que de novo e de mais precioso recebera do Humanismo, não tem ilusões sobre a decadência que começava a afectar, em seu entender, a comunidade lusíada" (PINA MARTINS, 1991, p. 1036). Pina Martins (1991, pp. 1038 e 1039) frisa então o caráter 
profético da obra mirandina, ao ponderar que a decadência efetivamente se instalou em Portugal. A profecia de Sá de Miranda - na sua mirada ao futuro - é a decadência portuguesa vivida por Pessoa que, lançando uma mirada ao passado, tenta reviver uma glória já extinta.

O poema III de "Chuva Oblíqua" segue a mesma linha do poema I. O sonho é o único "lugar" onde as seqüências de imagens e idéias apresentadas são possíveis. Interessante notar que o ato de escrever está presente no sonho: as seqüências de imagens se processam enquanto o poeta escreve. E o grande tema visivelmente tratado no poema é o Egito. Uma possível explicação para essa escolha de tema é - além da natural atração que o exótico exerce sobre alguns espíritos - o fato de que, ao tempo da publicação do poema, o Egito estava no proscênio científico internacional em virtude das escavações arqueológicas promovidas pela Inglaterra e das grandes descobertas feitas, já que o Egito e grande parte da África eram protetorados ingleses ${ }^{64}$.

O fenômeno da intersecção ocorre entre o espaço correspondente à escrivaninha do poeta, onde ele desempenha seu ofício de escrever e o longínquo país africano, berço de uma civilização antiqüíssima e da qual apenas sobraram ruínas, o que reforça o seu "charme" de lugar exótico. De maneira que a intersecção se dá entre duas realidades não só distintas, más também distantes no espaço e no tempo.

A primeira estrofe do poema fornece uma imagem de intersecção de matéria corpórea do mundo físico na qual, através da mão que escreve e que se torna

\footnotetext{
${ }^{64}$ Giovanni Arrighi. O longo século XX: dinheiro, poder e as origens do nosso tempo. Tradução de Vera Ribeiro. São Paulo: Ed. UNESP, 1996.
} 
translúcida, o eu poético vê a paisagem egípcia no papel. Tendo-se em conta que o tema é o Egito, verifica-se que o poeta faz um exercício de metalinguagem com o leitor. É como se ele sugerisse que a sua capacidade de criar imagens com palavras é tão forte, que ao escrever sobre determinado tema, este surge como uma pintura no papel onde existiriam somente letras. Mas como a estética adotada é o Interseccionismo, as paisagens superam os limites bidimensionais do papel e surgem em três dimensões para interseccionar-se com os objetos que cercam a folha.

Na segunda estrofe, a intersecção de objetos do mundo físico vai além da co-ocupação de um lugar no espaço. A co-ocupação passa a ser uma co-existência de dois objetos em um: "perturbo-me de vêr o bico da minha penna / Ser o perfil do rei Cheops...”. O bico da pena não se intersecciona com o perfil do rei Cheops, ela efetivamente é o perfil. Seguindo esse raciocínio, ver um objeto é perceber-se distinto dele. E, nesse mundo confuso e de sonho criado por Fernando Pessoa, é possível apenas distinguir-se a si mesmo do que está em volta, mas nunca determinar o que é visível, ou exterior ao próprio ser. Os adornos no bico de uma caneta de pena são bastante parecidos com os desenhos de rosto em perfil que faziam os antigos egípcios. Pessoa se valeu desse fato para que as imagens que criava ficassem mais claras.

Essa impotência para determinar o que é exterior a si constitui um fator de angústia para o sujeito poético, como indicam os versos seis, sete, oito e nove. O poeta que escrevia e produzia sua arte pára de repente e se encontra na escuridão, que em nada difere da situação de quem, ainda que na luz, não consegue determinar o que vê. Sem ter como guiar-se nessas "trevas", o eu mergulha no abismo de tempo que separa as duas realidades que se interseccionam: o Egito antigo e o local de trabalho do escritor. E diante 
da pequenez da sua humilde escrivaninha, se comparado ao gigante dos faraós, se vê soterrado pelas pirâmides. A intersecção de dois universos tão desproporcionais só poderia provocar o esmagamento de um deles. A sensação do poeta lembra o que disse Napoleão às suas tropas quando se encontravam em campanha no Egito: "Do alto destas pirâmides, quarenta séculos vos contemplam”. O poeta não é soterrado apenas pela grandiosidade da civilização egípcia, mas também pela sua antiguidade.

Uma das características da vanguarda poética é a de não apresentar respostas ou soluções para os problemas que suscita, as quais serão construídas pelo leitor por meio de um intercâmbio que ele realiza com o texto poético em sua atividade de leitura. A poética vanguardista se encarrega de fornecer imagens dispersas e independentes, e cabe ao leitor relacioná-las de acordo com a sua própria imaginação crítica e capacidade de raciocínio. Logo, seria extremamente temerário afirmar que a interpretação que ora se apresenta nesta dissertação é absolutamente autêntica e verdadeira, já que ela é fruto de uma leitura nossa, realizada com os instrumentos de análise que nós tínhamos à disposição.

Outros leitores - valendo-se de outros instrumentais técnicos e teóricos e dotados de outras habilidades no que se refere à imaginação crítica e capacidade de raciocínio, ou até mesmo com outras histórias de vida - seguramente farão outras leituras desses poemas e enxergarão outras idéias. A interpretação completamente correta e segura é algo imponderável. Mas é esse difícil exercício mental de análise e interpretação que torna a poesia vanguardista fascinante.

Vejam-se agora os seguintes poemas de Fernando Pessoa ortônimo, que também servem de base para o exame do processo de "mergulho íntimo" do eu poético. O 
primeiro é o poema III de "Episódios - A múmia" publicada na revista Portugal Futurista, $\mathrm{n}^{\mathrm{o}} 1,1917$; o segundo é o poema cujo primeiro verso é "Hoje que a tarde é calma e o céu tranqüilo". Incidentalmente, tentar-se-á fazer um paralelo entre o processo de mergulho íntimo, a questão da cisão de personalidade do sujeito poético - que, em Pessoa, se exacerbou de tal forma que gerou a poesia heteronímica - e a obra de Vincent Van Gogh, mais precisamente seus auto-retratos.

De quem é o olhar

Que espreita por meus olhos?

Quando penso que vejo,

Quem continua vendo

Enquanto estou pensando?

Por que caminhos seguem,

Não os meus tristes passos,

Mas a realidade

De eu ter passos comigo?

Às vezes, na penumbra

Do meu quarto, quando eu

Para mim próprio mesmo

Em alma mal existo,

Toma um outro sentido

Em mim o Universo -

É uma nódoa esbatida

De eu ser consciente sobre

Minha idéia das coisas.

Se acenderem as velas

E não houver apenas

A vaga luz de fora -

Não sei que candeeiro

Aceso onde na rua -

Terei foscos desejos

De nunca haver mais nada

No Universo e na Vida

De que o obscuro momento

Que é minha vida agora

Um momento afluente

Dum rio sempre a ir

Esquecer-se de ser,

Espaço misterioso 
Entre espaços desertos

Cujo sentido é nulo

E sem ser nada a nada.

E assim a hora passa

Metafisicamente. $^{65}$

Hoje que a tarde é calma e o céu tranqüilo,

E a noite chega sem que eu saiba bem,

Quero considerar-me a ver aquilo

Que sou, e o que sou o que é que tem.

Olho por todo o meu passado e vejo

Que fui quem foi aquilo em torno meu,

Salvo o que o vago e incógnito desejo

De ser eu mesmo de meu ser me deu.

Como a páginas já relidas, vergo

Minha atenção sobre quem fui de mim,

E nada de verdade em mim albergo

Salvo uma ânsia sem princípio ou fim.

Como alguém distraído na viagem,

Segui por dois caminhos par em par.

Fui com o mundo, parte da paisagem;

Comigo fui, sem ver nem recordar.

Chegado aqui, onde hoje estou, conheço

Que sou diverso no que informe estou.

No meu próprio caminho me atravesso.

Não conheço quem fui no que hoje sou.

Serei eu, porque nada é impossível, Vários trazidos de outros mundos, e No mesmo ponto espacial sensível

Que sou eu, sendo eu por 'star aqui?

Serei eu, porque todo o pensamento

Podendo conceber, bem pode ser,

Um dilatado e múrmuro momento,

De tempos-seres de quem sou o viver? ${ }^{66}$

\footnotetext{
${ }^{65}$ Fernando Pessoa. Obras completas de Fernando Pessoa vol. I - poesias de Fernando Pessoa. $11^{\text {a }}$ edição. Lisboa: Edições Ática, 1980. pp. 66-68.

${ }^{66}$ Fernando Pessoa. Obras completas de Fernando Pessoa vol. I- poesias de Fernando Pessoa. $11^{\text {a }}$ edição. Lisboa: Edições Ática, 1980. pp. 138 e 139.
} 
No que se refere ao aspecto estritamente estético dos poemas, o primeiro é composto de trinta e sete versos hexassílabos distribuídos em quatro estrofes, sendo a primeira, a segunda e a quarta de nove versos e a terceira de dez versos. As rimas, quando ocorrem, são toantes. O segundo poema é composto de vinte e oito versos decassílabos distribuídos em sete estrofes de quatro versos cada uma. As rimas são intercaladas e todas são consoantes. Os decassílabos variam entre heróicos e sáficos.

Os dois poemas apresentam um sujeito poético introspectivo e mergulhado sobre si mesmo, seus pensamentos e inquietações. A recorrência das frases interrogativas deixa patente a dúvida que atormenta a alma e indica a busca das respostas na qual se ocupa o poeta nos seus momentos de reflexão. Diante do desconhecimento de si, o sujeito procura o auto-conhecimento no "mergulho íntimo".

A primeira estrofe do segundo poema descreve o que seria o momento favorável ao mergulho íntimo. De acordo com a descrição, o silêncio e a escuridão da noite fornecem o ambiente propício à introspecção. O movimento diurno, o barulho e as injunções do trabalho impedem que o sujeito se volte para si e passe a perscrutar a sua intimidade. Eliminada toda essa interferência exterior, o caminho para a exploração dessa grande seara interior está aberto. A poesia épica, a lírica amorosa, a exaltação da natureza e dos valores de identidade coletiva já devassaram de tal modo os fatos do mundo e da vida, que estes perderam o interesse. A grande justificativa da escrita intimista é justamente o fato de que, uma vez esgotados os temas relacionados com o mundo externo, resta investigar o território íntimo. 
$\mathrm{Na}$ segunda estrofe, o sujeito poético lança um olhar sobre o próprio passado. O presente e a condição atual é irremediavelmente fruto da experiência já vivida. Tal experiência se dá na relação com o outro, como se fosse o externo determinando - ou, pelo menos, influenciando fortemente - o interno. No entanto, em oposição a todos os influxos das relações intersubjetivas experimentadas pelo sujeito poético, e constituindo mesmo uma exceção a eles, está o íntimo anelo de exercitar livremente a própria individualidade. Essa sede de si mesmo só pode nascer do próprio indivíduo: tem um caráter personalíssimo.

O olhar para o passado é seguidamente repetido e retomado na busca pelo real significado da própria existência, como bem demonstram os dois primeiros versos da terceira estrofe. Se o passado é como "páginas já relidas", isto significa que ele está sendo permanentemente revisitado. A atenção do sujeito poético está dirigida para a sua personalidade e o que ela efetivamente foi. Mas a única constatação possível é a de que este aspecto verdadeiro e real da personalidade simplesmente não existe, e a única certeza é a busca, que agora se revela infrutífera, mas ainda assim continua. Como sugere o último verso da estrofe, o desejo de viver plenamente é inato à condição humana, pois é "uma ânsia sem princípio ou fim". Logo, o sujeito não concebe nenhum instante da vida livre dele.

A conseqüência da viagem aos mais profundos meandros do eu é a inevitável cisão, já que o sujeito nem se dá conta da divisão que se opera, como sugerem os versos "Como alguém distraído na viagem, / Segui por dois caminhos par a par.”. O sujeito poético reconhece duas vertentes da sua personalidade: a que está voltada para o mundo exterior, e a que se volta para dentro de si numa atitude de auto-investigação. Os dois 
versos seguintes apresentam-nas como diametralmente opostas. A primeira se insere no mundo de maneira acrítica, pois se dissolve nas vicissitudes da vida para se tornar meramente "parte da paisagem"; e a segunda se aparta do mundo para vivenciar o mergulho íntimo.

A quinta estrofe mostra um sujeito poético que, diante de si mesmo, se estranha e se desconhece. No ponto em que chegou e onde se encontra, o sujeito percebe que as incertezas da busca e a verdade inatingível o tornaram um ser amorfo. $\mathrm{O}$ eu cindido aparece de maneira inequívoca ao sujeito poético pela verificação clara de que a experiência do mergulho íntimo promoveu mudanças radicais e insanáveis. Essas mudanças geraram dois seres antagônicos e irreconciliáveis: o eu que foi e o eu que é. A convivência desses dois desdobramentos do eu poético revela-se dolorosa, pois um se atravessa no caminho do outro e, apesar de irremediavelmente unidos, não se reconhecem. Mas ela é necessária, pois ainda que paulatinamente abrandado pelo efeito do tempo, o passado sempre sobrevive.

O poema termina de forma dramática para o sujeito poético. As duas últimas estrofes do poema espelham a dúvida em que está mergulhado. $\mathrm{O}$ resultado do mergulho íntimo é a indefinição. O sujeito poético formula duas interrogações, uma em cada estrofe.

A penúltima estrofe retrata aquele tipo de dúvida que abre ao sujeito infinitas possibilidades e o deixa paralisado pela perplexidade. No plano interior do ser não existe o impossível, como propõe o verso "Serei eu, porque nada é impossível”. O sujeito poético identificou duas vertentes do eu e, se nada é impossível, não há razões para duvidar 
de que existem outras, ou seja, se o eu é duplo, ele pode ser múltiplo. Mas o sujeito poético ainda vai mais longe nas possibilidades que a dúvida traz: a multiplicidade do eu poderia comportar entes "trazidos de outros mundos". E, como consta no terceiro verso da estrofe, todos reunidos "no mesmo ponto espacial sensível”, que é o próprio sujeito poético.

A última estrofe retoma a questão do ser no tempo sempre em mutação. O substantivo composto "tempos-seres" indica que há um ser - ou um desdobramento do ser - para cada tempo: o eu que foi, o eu que é, e, quem sabe, o eu que será. Todos coexistindo dentro do sujeito poético em permanente tensão. Para o sujeito poético, o ser é uma universalidade de desdobramentos incapazes de se redobrarem para compor uma unidade, pois como já se viu antes, são inconciliáveis. O caminho para a heteronímia estava aberto.

O poema III de "Episódios - A múmia" começa com frases interrogativas. Estas são o ponto de partida para o mergulho íntimo, do qual resultará a cisão do eu poético. A primeira interrogação do poema apresenta duas atitudes diferentes para um mesmo ato. "Olhar" e "espreitar" são ações distintas. A primeira é corriqueira e superficial, ao passo que a segunda implica necessariamente um comprometimento investigativo por parte do sujeito. Temos, portanto, duas ações que não podem ser praticadas simultaneamente pelo mesmo ser. A segunda interrogação já supõe diretamente a existência de dois seres paralelos: um que pensa e um que vê. Este mantém o contato com o mundo exterior e colhe as suas influências, e aquele reflete e transforma essas informações para que elas adquiram um caráter existencial e se incorporem a ele. Verificada a existência de um desdobramento de si, o sujeito poético se angustia por não saber que caminho seguir tendo passos consigo, e a que destino essa realidade o levará. 
A segunda estrofe faz menção ao lugar propício para o mergulho íntimo. O isolamento do mundo, o silêncio, a ausência de luz são invariavelmente os elementos que compõem o cenário no qual o sujeito poético, mergulhado em seus pensamentos, esquadrinha a própria intimidade. A partir daí, o sujeito poético exprime toda a dor de estar só com os seus pensamentos. Duvida da própria existência e assim o Universo adquire outro significado: é uma marca borrada que tende a desaparecer nas incertezas. Afinal, se a existência é incerta, que segurança se pode ter das próprias idéias e da consciência?

A dúvida e a incerteza do sujeito poético o fazem pensar que o momento em que vive é obscuro. Isso é natural, já que a dúvida insolúvel só pode conduzir à obscuridade. Mas o momento não é autônomo no grande tempo da Vida e do Universo. Antes é seu tributário, como na imagem criada nos dois primeiros versos da última estrofe. A vida é como um grande rio, do qual os momentos específicos são os afluentes que, nele desaguando um após o outro, aumentam-lhe o volume do leito. A conclusão do sujeito poético é niilista, a experiência do mergulho íntimo é reduzida a nada. As palavras de Fernando Pessoa são suficientes, pois in claris cessat interpretatio: o território íntimo é um “espaço misterioso / Entre espaços desertos / Cujo sentido é nulo / E sem ser nada a nada".

A obra de Vincent Van Gogh, principalmente seus auto-retratos, está estreitamente relacionada à questão da dilaceração da personalidade, que ocupou a mente dos poetas da escrita intimista. Tal questão envolve diversos aspectos da vida social experimentada pelos contemporâneos de Van Gogh e continua a afligir o ser humano nos dias de hoje, seja pelo seu caráter de atemporalidade, seja por estar atualmente na sua fase de maior exasperação. 
A prática do auto-retrato é recorrente em Van Gogh, o que vem a demonstrar que a relação consigo mesmo é de fundamental importância para o fazer artístico do pintor. Entenda-se que a representação artística pressupõe sempre uma relação íntima entre o sujeito artístico e aquilo que ele representa. Tal relação estabelece-se primordialmente por meio dos sentidos, visto que ela é principalmente de percepção.

Ao contrário do que pode parecer, ainda que a pintura seja essencialmente uma arte visual, o contato que estabelece a relação mais íntima entre o artista e a inspiração da sua obra não necessariamente é a visão. Esta tende a ser apenas um contato introdutório e ainda distante da essência dos objetos do mundo. Muito mais proximidade supõem os outros sentidos. Camões, no episódio da Ilha dos Amores d'Os Lusíadas, faz em última análise um exercício de metalinguagem que suscita essa relação do artista com o mundo ${ }^{67}$. Ao descrever a relação com as musas - logo, com a fonte de inspiração, que na verdade é o motor do fazer artístico - Camões reflete sobre a relação do artista com o mundo que o cerca e como ela se processa. A aproximação dos navegantes patenteia a sua relação com a fonte de inspiração e a intensidade de cada fase desta relação. O primeiro contato é o visual, quando a tripulação da nau de Vasco da Gama avista a ilha; o segundo se dá por meio da audição, quando os tripulantes escutam o canto das musas e que já demonstra maior proximidade; os seguintes são o olfato e o tato, possíveis apenas quando se está muito próximo e a percepção dos objetos é muito mais certeira e precisa.

\footnotetext{
${ }^{67}$ Luís de Camões. Os Lusíadas. Edição comentada por Otoniel Mota. 10a edição. São Paulo: Edições Melhoramentos, 1956.
} 
Van Gogh tem uma relação intensa consigo mesmo, tanto na sanidade quanto na loucura; e demonstra essa relação no ato de auto-retratar-se, porquanto assume um duplo papel: sujeito e objeto. A percepção, como captação primária da realidade por meio do intelecto, tem como requisito a compreensão da relação de alteridade entre sujeito e objeto: perceber um objeto é perceber-se distinto dele. Isto se dá por via dos sentidos e, por meio de processos mentais, esta informação se converte em uma representação da realidade. Em Van Gogh, essa representação assume um caráter personalíssimo, pois antes de representar fielmente a realidade ele busca impor a sua visão das coisas do mundo.

Entretanto, no auto-retrato, o artista transcende a mera percepção sensorial empregada para os objetos exteriores, já que o auto-retrato de Van Gogh implica necessariamente o mergulho íntimo, ou seja, o conhecimento da própria personalidade. Conforme já foi dito, a atitude de voltar-se para o interior e perscrutar os meandros da própria personalidade generalizou-se na Literatura a partir de meados do século XIX, com a publicação das Flores do mal, de Charles Baudelaire, que foi, além de poeta e teórico da literatura, crítico de arte. Van Gogh, em sua obra, segue este caminho rumo ao próprio interior.

A auto-representação de Van Gogh ultrapassa os limites de uma relação consigo mesmo regida pela percepção sensorial, já que denota um estado de espírito, um tipo de temperamento. $\mathrm{O}$ mergulho íntimo é tão profundo que exclui o entorno. $\mathrm{O}$ fundo dos quadros é o mais absoluto nada. Da mesma cor que as roupas do artista, destas se diferencia apenas pelos traços contorcidos que o compõem e pelo contorno pesado do desenho, que confere uma luminosidade semelhante à de vitrais, fazendo com que a cor se projete de dentro da tela para fora, conforme a influência que o Cloisonismo exerceu nos 
pós-impressionistas. Quando o fundo é de cor diversa, sempre indica o nada em torno do eu, isolando-o do mundo. A investigação da própria intimidade realizada pelo artista, não se basta em isolar o objeto investigado da realidade exterior a ele para melhor compreendêlo, mas chega a anular todo e qualquer elemento estranho ${ }^{68}$.

A segunda metade do século XIX assiste à generalização do modo de produção capitalista nos países europeus. Depois de limitar-se à Inglaterra - até então a pioneira da Revolução Industrial - Países Baixos, França e Alemanha aderem a este novo paradigma econômico. No entanto, a ideologia burguesa de liberdade econômica e acesso livre à prosperidade já trazia em seu bojo todas as contradições inerentes ao capitalismo. A mão invisível do mercado da escola clássica inglesa e o laissez-faire, laissez-passer - le monde va de lui-même dos fisiocratas franceses não lograram proporcionar involuntariamente o bem estar da sociedade, e o contraste entre a opulência da burguesia industrial e a miséria do proletariado urbano ficava cada vez mais evidente. A expansão territorial através da África e da Ásia, promovendo a completa subjugação dessas regiões e o aniquilamento de qualquer possibilidade de auto determinação dos povos afro-asiáticos mostrou toda a incoerência da mentalidade burguesa ${ }^{69}$.

O grande paradoxo dessa Europa guiada por valores pretensamente liberais, mas que consagrava o imperialismo na sua política externa; e do sistema sócioeconômico que prometia crescimento, mas gerava pobreza, inquietava as mentes mais sensíveis. Diante desse mundo paradoxal, o indivíduo se voltava para si e seu universo interior, o que possibilitou o profundo mergulho íntimo. Neste sentido, Van Gogh é, na

\footnotetext{
${ }^{68}$ Roland Dorn et al. Van Gogh face to face: the portraits. Detroit: Thames \& Hudson, 2000.

${ }^{69}$ Giovanni Arrighi. O longo século XX: dinheiro, poder e as origens do nosso tempo. Tradução de Vera Ribeiro. São Paulo: Ed. UNESP, 1996.
} 
pintura, herdeiro de Kierkegaard, o qual, junto com Nietzsche, é considerado um dos precursores do Existencialismo. Kierkegaard dá início, na filosofia, à investigação desta grande seara que é o eu e que atingirá o seu ápice com Heidegger e Sartre, os grandes existencialistas do século $\mathrm{XX}^{70}$.

Mas o mergulho íntimo não se mostra produtivo, pois não é revelador de nada. Ao não encontrar as respostas para as suas aflições dentro de si e diante da impossibilidade de encontrá-las no mundo incongruente e contraditório em que vive, o homem desenvolve uma profunda angústia. O semblante de Van Gogh nos seus autoretratos denuncia toda a dor de um indivíduo que não encontra lugar nem no mundo nem em si mesmo. A cores predominantes dão aos quadros um tom melancólico e o nada que cerca a sua figura retratada, além de dar a real dimensão da profundidade do mergulho íntimo, mostra a solidão em que vive o sujeito artístico e a sua situação de não-lugar no mundo.

A personalidade totalmente deslocada e perdida acaba por fragmentarse. A busca de si mesmo cria a multiplicidade do eu, já que o artista experimenta várias possibilidades de auto-definição sem conseguir êxito. Van Gogh pintou a si mesmo mais de cinqüenta vezes. Tal profusão de auto-retratos já é uma criação artística em si e dotada de significado próprio dentro desse contexto histórico-social. Pode-se mesmo traçar um paralelo com a heteronímia pessoana, a qual deve ser entendida, nesta perspectiva, como criação poética derivada de um eu lírico dilacerado.

\footnotetext{
${ }^{70}$ Alexandre Caballero. A filosofia através dos textos. São Paulo: Editora Cultrix Ltda, 1972.
} 
Para o artista que percebeu a desumanidade de um mundo guiado por valores animalizantes não há lugar. A esse artista não foi reservado nenhum refúgio em um mundo onde o dinheiro é a medida de todas as coisas e a base de todas as relações sociais. Van Gogh sentiu a dor de entender que o belo não era o parâmetro da conduta humana, a qual passou a ser sinalizada pela sanha por capital e pelo "fetiche da mercadoria"71. Em Van Gogh, esse entendimento extrapolou a sua arte para efetivamente destruir sua a vida.

Já se disse que a corrente literária maneirista do século XVI está marcada pela antítese (HAUSER, 1995; SARDUY, 1979). A lírica da dilaceração e cisão do sujeito poético da poesia intimista pós-Simbolismo recepciona o tropo antitético por meio de um tropo recorrente no Interseccionismo: o oximoro, o qual é uma antítese levada ao extremo, onde um dos termos é negado pelo outro. A antítese maneirista ainda está fortemente relacionada com o traço contrastivo eu/outro, de maneira que há uma inegável solidariedade semântico-retórica entre a antítese, o duplo, o oximoro e o Interseccionismo. Senão, vejamos o que ocorre em Sá-Carneiro.

Em Escavação, tem-se o verso 11, “- Onde existo que não existo em mim?",72; em Álcool, tem-se o último verso "Manhã tão forte que me anoiteceu." ${ }^{, 73}$ No final de Dispersão, tem-se:

Perdi a morte e a vida, E, louco, não enlouqueço...

\footnotetext{
${ }^{71}$ Marx cria esse conceito a partir da observação do modo pelo qual a posse de bens valiosos (roupas caras e carros de luxo, por exemplo) interfere nas relações intersubjetivas, servindo como instrumento mediador nas relações entre as pessoas. Como explica Norman Geras, "Marx nos diz que, na sociedade capitalista, os objetos possuem certas características que lhes são conferidas pelas relações sociais dominantes, mas que aparecem como se lhes pertencessem naturalmente. Essa síndrome, que impregna a produção capitalista, é por ele denominada fetichismo, e sua forma elementar é o fetichismo da mercadoria enquanto repositório ou portadora de valor". FETICHISMO. In: Dicionário do pensamento marxista. Editado por Tom Bottomore. Rio de Janeiro: Jorge Zahar Editor, 1993. pp. 149 e 150.

${ }_{73}^{72}$ Mário de Sá-Carneiro. Op. Cit. p. 55.

${ }^{73}$ Idem, p. 59.
} 
A hora foge vivida

Eu sigo-a, mas permaneço...

Castelos desmantelados,

Leões alados sem juba...

Em Como eu não possuo, retro citado, têm-se o terceiro e quarto versos

da terceira quadra:

Falta-me egoísmo para ascender ao céu,

Falta-me unção para me afundar no lodo. ${ }^{75}$

Os dois versos anafóricos ilustram a oscilação generalizada entre duas tendências opostas: a sublimação e a degeneração. Tal como os poetas que vivenciaram o conflito entre as duas direções que a construção da personalidade humana pode seguir, segundo Giovanni Pico Della Mirandola, no ciclo temático do "inimigo de si" do Quinhentismo literário português, Sá-Carneiro experimenta a mesma sensação e a tematiza no seu fazer poético. A queda é um poema representativo do problema:

\section{A QUEDA}

E eu que sou o rei de toda esta incoerência, Eu próprio turbilhão, anseio por fixá-la

E giro até partir... Mas tudo me resvala

Em bruma e sonolência.

Se acaso em minhas mãos fica um pedaço de oiro, Volve-se logo falso... ao longe o arremesso... Eu morro de desdém em frente dum tesoiro, Morro à míngua, de excesso.

Alteio-me na cor à força de quebranto, Estendo os braços de alma - e nem um espasmo venço!...

Peneiro-me na sombra - em nada me condenso...

Agonias de luz eu vibro ainda entanto.

\footnotetext{
${ }^{74}$ Idem, p. 65.
}

${ }^{75}$ Idem, p. 70. 
Não me pude vencer, mas posso-me esmagar,

- Vencer às vezes é o mesmo que tombar -

E como inda sou luz, num grande retrocesso,

Em raivas ideais ascendo até ao fim:

Olho do alto o gelo, ao gelo me arremesso...

Tombei...

E fico só esmagado sobre mim!... ${ }^{76}$

Em A queda, duas naturezas distintas e incoerentes coexistem no sujeito poético. Ambas se referem ao eu. Logo, estão em igualdade de forças. Se não podem vencer uma à outra, esmagam-se mutuamente. Portanto, não há vencedor ou vencido, mas apenas o impasse representado pelo eu esmagado - e paralisado como o "pilar da ponte de tédio". Esse eu composto de contrários se expressa por meio de oximoros: "Morro à míngua, de excesso” (quarto verso da segunda quadra); “- Vencer às vezes é o mesmo que tombar -" (segundo verso da quarta estrofe). É um eu ao mesmo tempo débil e forte. Em Mário de Sá-Carneiro, o oximoro passa a ser a figura do eu por excelência, conforme se verifica pelo radical oximoro do primeiro verso do retro citado poema 7: " eu não sou eu".

Jean-Paul Sartre se aproxima da concepção piquiana de homem, enquanto ser onticamente indefinido, ao proclamar que "a existência precede a essência" (SARTRE, 1987, p. 5). O filósofo entende que o homem, ou a "realidade humana", não está pré-concebido a partir de uma característica genérica inerente à condição humana. Para ele, é justamente nisso que reside a dignidade do homem. Segundo Sartre, "em primeira instância, o homem existe, encontra a si mesmo, surge no mundo e só posteriormente se define" (1987, p. 6). Logo, a possibilidade de escolha que o homem da concepção sartreana

\footnotetext{
${ }^{76}$ Idem, pp. 79 e 80.
} 
tem é análoga à da concepção piquiana, pois para Pico o homem pode seguir duas tendências: a sublimação e a degeneração. Porém, para Sartre, não há juízo de valor quanto ao caminho escolhido, já que o grande referencial de Pico - ou seja, Deus - é eliminado em Sartre. O poema de Sá-Carneiro espelha essa concepção de homem dividido e, mais do que isso, indefinido. A ausência de um juízo axiológico para as opções de auto-edificação humana proposta por Sartre patenteia-se no poema.

A poetisa Maria Teresa Horta relê o tema do "inimigo de si" pela perspectiva de uma lírica intimista feminina, no seu poema "Minha senhora de mim". Recuperemos o poema:

Minha senhora de mim
Comigo me desavim
minha senhora
de mim
sem ser dor ou ser cansaço
nem o corpo que disfarço
Comigo me desavim
minha senhora
de mim
nunca dizendo comigo
o amigo nos meus braços
Comigo me desavim
minha senhora
de mim
recusando o que é desfeito
no interior do meu peito

O diálogo com Sá de Miranda e a presença da cisão do sujeito poético pela retomada do tema do "inimigo de si" evidenciam-se pela citação reiterada do verso

\footnotetext{
${ }^{77}$ Maria Teresa Horta. Poesia completa 1967-1982. Lisboa: Litexa, 1983. vol. 2. p. 56.
} 
“Comigo me desavim”. Mas há algo que singulariza a recepção do tema: o eu lírico do poema é feminino. O poema de Maria Teresa Horta inscreve-se no ciclo temático do intimismo feminino $^{78}$, ao qual pertencem poetisas como Florbela Espanca, em Portugal e Dulce María Loynaz, Juana Rosa Pita, Carlota Caufield, Gertrudis Gómez de Avellaneda etc. na América Hispânica.

O poema associa a questão feminina e a cisão do eu lírico em virtude de um conflito íntimo. Como explica Marlise Vaz Bridi (2005, p. 233): “O poema 'Minha senhora de mim' coloca as dissensões à mostra: as internas e pessoais que se exteriorizam e as exteriores e sociais que se internalizam. O aparente poder que ser 'senhora' de si aponta, logo se desfaz na desavença ('Comigo me desavim') de silenciar o corpo ('nem o corpo que disfarço') e na confusão dos afetos ('recusando o que é desfeito/no interior do meu peito')".

O poema se desenvolve em três conflitos do eu poético feminino, apresentados a cada cinco versos, onde os três primeiros - que se repetem - indicam o conflito e os dois últimos revelam o motivo do conflito. A natureza do primeiro e terceiro conflito já foi apontada com muita propriedade por Marlise Vaz Bridi. Entretanto, poderse-ia ir mais longe na leitura, relacionando o "amigo nos meus braços" (verso 11) com o homem amado e sexualmente desejado. O sujeito poético feminino entrou em conflito consigo mesmo por se ver impedido de viver abertamente e plenamente um amor.

\footnotetext{
${ }^{78}$ Jesús J. Barquet. Escrituras poéticas de uma nación. La Habana: Ediciones Unión, 1999.
} 
A recepção do tema por parte dos poetas contemporâneos apresentou todo tipo de reação. Inclusive jocosas, como a do poeta Alexandre O'Neill no seu poema "Sá de Miranda Carneiro":

comigo me desavim

eu não sou eu nem sou o outro

sou posto em todo perigo sou qualquer coisa de intermédio não posso viver comigo pilar na ponte de tédio não posso viver sem mim que vai de mim para o Outro ${ }^{79}$

O poema consiste de uma montagem em tom de brincadeira feita alternando-se versos de dois poemas de Sá de Miranda e de Sá-Carneiro já apresentados acima. O poeta aproveita-se até da coincidência de parte dos nomes dos autores dos poemas citados para dar título ao poema citante. A tônica predominante é a da ludicidade. Alexandre O’Neill não sofre do mesmo mal que Sá de Miranda e Sá-Carneiro (a cisão subjetiva do sujeito poético), ou pelo menos não o demonstra no seu poema. Logo, "não há uma vivência subjetiva deste conflito, mas [...] apenas uma desconstrução vanguardista dos mitos do imaginário poético português" (FRANCO, 2001, p. 111). O mais interessante, no entanto, é a verificação do nexo temático entre os dois Sás não por um crítico, mas por um poeta. Nesse sentido, o poema de Alexandre O’Neill é metalingüístico, pois ao explorar poeticamente a recepção poética, é poesia sobre poesia.

Em que pesem a perspicácia e a imaginação crítica de David MourãoFerreira ao relacionar o "inimigo de si” à écloga e esta à heteronímia pessoana (FRANCO, 2001, p. 38), ainda há mais. A obra de Fernando Pessoa recepcionou o tema do "inimigo de

\footnotetext{
${ }^{79}$ Alexandre O’Neill. Poesias completas - 1951/1983. $2^{\mathrm{a}}$ edição revista e aumentada. Lisboa: Biblioteca de Autores Portugueses - Imprensa Nacional - Casa da Moeda, 1984. p. 373.
} 
si" na sua poesia miúda. Vejam-se os seguintes poemas de sua autoria, em forma de redondilha:

\author{
Repousa sobre o trigo \\ Que ondula um sol parado. \\ Não me entendo comigo. \\ Ando sempre enganado. \\ Tivesse eu conseguido \\ Nunca saber de mim, \\ Ter-me-ia esquecido \\ De ser esquecido assim. \\ O trigo mexe leve \\ Ao sol alheio e igual. \\ Como a alma aqui é breve \\ Com o seu bem e mal! ${ }^{80}$
}

No mal-estar em que vivo,

No mal pensar em que sinto,

Sou de mim mesmo cativo,

A mim mesmo minto.

Se fosse outro fora outro.

Se em mim houvesse certeza,

Não seria o fluido e neutro

Que ama a beleza.

Sim, que ama a beleza e a nega

Nesta vida sem bordão

Que contra si mesma alega

Que tudo é vão. ${ }^{81}$

A recepção se dá por meio da intertextualidade, assim como no poema de Alexandre O’Neill “Sá de Miranda Carneiro”. Entretanto a intertextualidade que se apresenta aqui é de natureza diversa. Severo Sarduy (1979) reconhece dois tipos de intertextualidade: a citação, definida como "a incorporação de um texto estranho ao texto, sua colagem ou superposição à superfície do mesmo - forma elementar do diálogo - sem

\footnotetext{
${ }^{80}$ Fernando Pessoa. Obras completas de Fernando Pessoa vol. I - poesias de Fernando Pessoa. $11^{\mathrm{a}}$ edição. Lisboa: Edições Ática, 1980. p. 178.

${ }^{81}$ Idem, p. 188.
} 
que por isso nenhum dos seus elementos se modifique, sem que sua voz se altere"; e a reminiscência, definida como a "forma mediata de incorporação em que o texto estranho se funde com o primeiro, indistinguível, sem implantar suas marcas, sua autoridade de corpo estranho na superfície, mas constituindo os estratos mais profundos do texto receptor, tingindo suas redes, modificando com suas texturas sua geologia" (SARDUY, 1979, p. 71). Em "Sá de Miranda Carneiro", tem-se a citação; nos dois poemas de Fernando Pessoa supra citados tem-se a reminiscência.

A citação, conforme se depreende do que preconiza Jorge Luís Borges (1976), não significa a mera cópia vazia de sentido. A pretensão de Pierre Menard ${ }^{82}$ de escrever a história de Cervantes nos dias atuais não se refere a uma versão atual e adaptada ao tempo presente, mas a escrever exatamente o mesmo que o autor espanhol, realizando uma reprodução idêntica ao original. Uma adaptação significaria uma tentativa de, entendendo o presente, mudar o que tenha que ser mudado no texto para recuperar o impacto da obra no passado e reproduzi-lo no presente. Para Borges, a recepção (ou discursividade) depende do discurso originário e do momento de veiculação desse discurso. A adaptação seria reproduzir a recepção em um momento diverso, alterando o discurso. No entanto, o lapso temporal de três séculos impõe necessariamente uma diferença. Esta diferença não está no texto literário, mas no seu entorno, isto é, no seu contexto histórico. Este é irrecuperável e o anacronismo será inevitável, conforme o ensinamento de Ítalo Calvino (1997) de que a recepção se opera cumulativamente pelas leituras consecutivas levadas a efeito desde o aparecimento de uma obra. Logo, a discursividade que uma obra produzirá - ou seja, a recepção - é algo absolutamente imponderável a priori. Borges ilustra

\footnotetext{
82 Jorge Luís Borges. "Pierre Menard, autor del Quijote". In: Aires: Alianza Editorial/Emecé Editores, 1976. 
essa concepção com a história narrada em seu conto fantástico "Pierre Menard, autor del Quijote". Menard escreve o mesmo texto de Cervantes, mas o seu significado não poderá ser o mesmo, pois o contexto sócio-histórico que recebeu aquele texto em 1605 já está historicamente morto no século XX. Note-se que o conto de Borges, como o poema de O’Neill, é metalingüístico, pois ao tratar da recepção do texto literário, é literatura sobre literatura.

Disso se conclui que um poema citante não copia o poema citado, pois o mesmo texto tem sentidos distintos em momentos distintos. No poema de O’Neill, o tema do "inimigo de si" não assume a dimensão terrível de dilaceração do sujeito poético, mas propõe uma reavaliação dos pressupostos tradicionais do lirismo português. Conforme explica Marcia Arruda Franco (2001, p. 116), "aqui se evidencia a recusa da poética experimental de O’Neill em resguardar os lugares-comuns da poesia portuguesa". Alexandre O’Neill faz inclusive uma pequena alteração no último verso da quadra mirandina que serve à montagem: "Nem posso fugir de mim" se transforma em "Não posso viver sem mim". Esta alteração promove um paralelismo com o verso "não posso viver comigo", o que banaliza o conflito íntimo. Marcia Arruda Franco esclarece que "a seriedade do mito do 'inimigo de si', definidora de um modo de ser português: aquele que se auto-rejeita e se compraz no sofrimento, na pena de O'Neill, é ironizada, através de um jogo com a lógica sintático-semântica da citação" (FRANCO, 2001, p.116). Fica claro que, no poema de O’Neill e nos de Sá de Miranda e Sá-Carneiro, o texto tem objetivos diametralmente opostos.

A intertextualidade nos poemas de Pessoa é do outro tipo - a reminiscência. Sem surgir nitidamente na parte visível do texto, mas sempre subentendido, 
o "inimigo de si" perpassa os dois poemas retro citados, conferindo um teor arcaico aos mesmos. O terceiro e quarto versos da primeira estrofe do primeiro poema - "Não me entendo comigo/Ando sempre enganado" - parafraseiam o "comigo me desavim" de Sá de Miranda e o "grande engano" de Bernardim Ribeiro. A segunda estrofe - "Tivesse eu conseguido/Nunca saber de mim/Ter-me-ia esquecido/De ser esquecido assim" relê o “agora, já fugiria/de mim, se de mim pudesse” de Sá de Miranda.

O segundo poema apresenta uma releitura do tema do "inimigo de si" composta por elementos mais difusos no texto. O dois primeiros versos, "No mal-estar em que vivo,/No mal pensar em que sinto" deixam claro o desconforto emocional do sujeito poético. Os dois versos seguintes ("Sou de mim mesmo cativo,/A mim mesmo minto”) já se referem ao "inimigo de si": aquele que aprisiona só pode ser um inimigo, e aquele a quem se mente também. A partir daí, a recepção do tema passa a ser extremamente sutil. $\mathrm{O}$ sujeito poético entrevê a possibilidade de ser outro (primeiro verso da segunda estrofe) - o que implica despersonalização - o qual não padeceria dos seus males. Dois grandes tormentos afligem o sujeito: o sentimento paradoxal de ao mesmo tempo amar e negar a beleza (quarto verso da segunda estrofe e primeiro verso da terceira); e a fragilidade da sua vida sem arrimo ("bordão"), que "contra si mesma alega que tudo é vão". Contra si porque ela própria está incluída no tudo e, logo, é vã. 


\section{Tentativa de conclusão}

Assim como o tema específico do "inimigo de si”, relido intertextualmente por Pessoa, o tema mais geral da cisão do eu poético na lírica portuguesa pós-Simbolismo pode ser tido como um produto de uma intertextualidade, do tipo reminiscência, com a lírica quinhentista portuguesa. $\mathrm{O}$ eu poético cindido do cancioneiro renascentista português está presente na lírica modernista de Pessoa e Sá-Carneiro sem necessariamente aflorar à superfície do texto visível a todo instante como citação, mas permeando o texto literário, determinando o seu conteúdo poético, enquadrando-se no que Severo Sarduy chama de reminiscência. Em permanente estado de latência, surge de maneira mais ou menos clara (e às vezes de maneira extremamente sutil) nos poemas.

O conceito de intertextualidade operada pela reminiscência, de Sarduy, não exclui a proposição de Borges quanto à questão do momento em que se insere a obra literária (já que o conto de Borges trabalha com o que Sarduy chamaria de citação). Caberia, então, uma indagação sobre o significado da cisão do sujeito poético na lírica portuguesa moderna. Pela natureza dessa indagação, qualquer resposta seria temerária. É possível apenas uma tentativa de esboço, já que inclusive Costa Lima (2005, p. 407) conclui seu magistral trabalho declarando que se sabe seguramente "apenas que a sagração do indivíduo há muito perdeu o chão".

Norbert Elias (1994) propõe que não existe individualidade que não esteja relacionada ao outro e por ele definida, e que a privatização da vida está intrinsecamente ligada à civilização. Para ele, individualidade de uma pessoa é "uma peculiaridade de suas funções psíquicas, uma qualidade estrutural de sua auto-regulação em 
relação a outras pessoas e coisas" (ELIAS, 1994, p. 54). É com naturalidade que proclama que "a sociedade não apenas produz o semelhante e o típico, mas também o individual" (ELIAS, 1994, p. 56) e que “cada 'eu' está irrevogavelmente inserido num 'nós"” (ELIAS, 1994, p. 57), sem deixar de reconhecer as cisões decorrentes da tensão entre o que se faz necessário e é esperado na sociedade e a "verdade interior" (ELIAS, 1994, p. 33).

O marxismo propugna como meta a auto-criação do indivíduo em suas relações sociais, como único modo de respeitar a dignidade da condição humana, de desenvolvimento da humanidade e de aprimoramento dos meios de satisfação das necessidades humanas. Mas não no sentido estreito do individualismo, e sim de necessidades historicamente constituídas do indivíduo universal.

Diversa é a visão do existencialismo de orientação sartreana. Sartre desconsidera Hegel e Marx quando propõe o restabelecimento dos direitos do irredutivelmente humano, como resposta ao que ele considera determinismo mecânico. Assim, os existencialistas se afastam do entendimento marxista de que o indivíduo só pode ser livre e pleno no interior da classe a que pertence. Apresentam então uma concepção de indivíduo que não é a totalidade de suas relações sociais, mas solitário, impotente e fragmentado. Pelo teor dos poemas que serviram de base às nossas reflexões, parece ser este um razoável significado da cisão.

O eu poético cindido está invariavelmente só, inerte diante de si mesmo, perplexo e se fazendo uma pergunta como “Que sortilégio a mim próprio lancei?”, intuindo que na sua solidão não há nenhum culpado além dele. Sem remédio possível, já que não pode vencer-se, esmaga-se e permanece só, esmagado sobre si. 


\section{REFERÊNCIAS}

ADORNO, Theodor W. "Lírica e sociedade". In: Benjamin, Walter. Et allii. Textos escolhidos. São Paulo: Abril (Col. "Os Pensadores), 1980.

ANASTÁCIO, Vanda. "Aparência e identidade no Auto dos Enfatriões de Camões". In: Estudos portugueses/Homenagem a Luciana Stegagno Picchio. Lisboa: Difel, 1991. pp. 519-568. ISBN 972-29-0044-7.

ARRIGHI, Giovanni. O longo século XX: dinheiro, poder e as origens do nosso tempo. Tradução de Vera Ribeiro. São Paulo: Ed. UNESP, 1996. 393 p. ISBN 8571391084.

BARQUET, Jesus J. Escrituras poéticas de una nación. Ciudad de La Habana: Ediciones Unión, 1999. 94 p. ISBN 959-209-290-7.

BACHELARD, Gaston. "Instante poético e instante metafísico". In: O direito de sonhar. Tradução de José Américo Motta Pessanha. Rio de Janeiro: Bertrand Brasil, 1991. pp. 183-189.

BENJAMIN, Walter. "O narrador". In: . Magia e técnica, arte e politica - Ensaios sobre literatura e história da cultura. Tradução de Sérgio Paulo Rouanet. $3^{\mathrm{a}}$ edição. São Paulo: Brasiliense, 1987. (Obras escolhidas v. 1) pp. 197-221.

. "Parque Central". In: Charles Baudelaire um lírico no auge do capitalismo. Tradução de José Carlos Martins Barbosa. São Paulo: Editora Brasiliense, 1989. (Obras escolhidas v. 3) pp. 151-181.

Biblioteca dell'eloquenza italiana di monsignore Giusto Fontanini arcivescovo d'Ancira, con le annotazione dell signor Apostolo Zeno istorico e poeta cesareo, cittadino veneziano. Accresciuta di nuove aggiunte. Tomo Primo. Per li Fratelli Gozzi. Con permissione. A spese di Luigi Mussi. Parma: Biblioteca Fagnani, MDCCCII.

BLOCH, R. Howard. Misoginia medieval e a invenção do amor romântico ocidental. Tradução de Cláudia Moraes. São Paulo: Editora 34, 1999.

BORGES, Jorge Luís. "Pierre Menard, autor del Quijote”. In: Ficciones. $5^{\mathrm{a}}$ edição. Madrid; Buenos Aires: Alianza Editorial/Emecé Editores, 1976. 208 p. ISBN 8420613207.

BRIDI, Marlise Vaz. "Entretempos na poesia de Maria Teresa Horta". In: FERNANDES, Annie Gisele; OLIVEIRA, Paulo Motta. Literatura portuguesa aquém-mar. Campinas: Editora Komedi, 2005. pp. 229-239. ISBN 85-7582-213-6.

CABALlERO, Alexandre. A filosofia através dos textos. São Paulo: Editora Cultrix LTDA., 1972. 272 p.

CALVINO, Ítalo. Por que ler os clássicos. São Paulo: Companhia das Letras, 1997. 
CAMÕES, Luis de. Lírica completa. Volumes I, II e III. Prefácio e notas de Maria de Lurdes Saraiva. Lisboa: Imprensa Nacional - Casa da Moeda, 1980.

. Teatro completo. Prefácio, notas e fixação do texto por Vanda Anastácio. $1^{a}$ edição. Porto: Edições Caixotim, 2005. 458 p. ISBN 972-8651-59-7.

. Os Lusíadas. Edição comentada por Otoniel Mota. $10^{\mathrm{a}}$ edição. São Paulo: Edições Melhoramentos, 1956. $401 \mathrm{p}$.

CANDIDO, Antonio. $O$ estudo analítico do poema. $3^{\text {a }}$ edição. São Paulo: Humanitas Publicações - FFLCH/USP, 1996. 103 p. ISBN 85-86087-06-8.

COSTA LIMA, Luiz. Limites da voz. $2^{\mathrm{a}}$ edição revisada. Rio de Janeiro: Topbooks Editora e Distribuidora de Livros Ltda., 2005. 444 p. ISBN 85-7475-100-6.

Dicionário do pensamento marxista. Editado por Tom Bottomore. Rio de Janeiro: Jorge Zahar Editor, 1993. ISBN 85-85061-79-0.

DESCARTES, René. Discurso do Método para conduzir bem sua razão e buscar a verdade nas ciências e mais a Dióptrica, os Meteoros e a Geometria que são ensaios dêsse método. Tradução, introdução e notas de João Cruz Costa. Rio de Janeiro: Edições de Ouro, 1965.

DORN, Roland. et al. Van Gogh face to face: the portraits. Detroit: Thames \& Hudson, 2000. 272 p. ISBN 0-89558-152-3.

DOVIZI, Bernardo, Bibbiena. La Calandria. Torino: G. Einaudi, 1967.

DUBY, Georges. Idade Média, idade dos homens. Tradução de Jônatas Batista Neto. São Paulo: Companhia das Letras, 1989. 214 p. ISBN 85-7164-16-5.

ELIAS, Norbert. A sociedade dos indivíduos. Organizado por Michael Schröter. Tradução de Vera Ribeiro. Revisão técnica e notas de Renato Janine Ribeiro. Rio de Janeiro: Jorge Zahar Editor, 1994. 201 p. ISBN 85-7110-278-3.

ERASMO DE ROTERDAM, Elogio da loucura. Tradução de Paulo M. Oliveira. Introdução de Antonio Olinto. Rio de Janeiro: Edições de Ouro, 1965. 210 p.

FRANCO, Marcia Arruda. Sá de Miranda, um poeta no século XX. Braga: Angelus Novus, 2001. 153 p. ISBN 972-8115-69-5.

. Sá de Miranda poeta do século de ouro. Coimbra: Angelus Novus, 2005. 182 p. ISBN 972-8827-28-8.

FRIEDRICH, Hugo. Estrutura da lírica moderna. Tradução do texto: Marise M. Curioni. Tradução das poesias: Dora F. da Silva. $2^{a}$ edição. São Paulo: Livraria Duas Cidades Ltda., 1991. $349 \mathrm{p}$. 
GRAJALES, Juan de. "El rey por semejanza". In: Dramáticos contemporaneos a Lope de Vega, por Gaspar Aguilar, Luís de Belmonte y Bermudes. Escogido y ordenado com um discurso, apuntes biográficos y críticos de los autores, noticias bibliográficas y catálogos por Don Ramón de Mesonero Romano. Colección Biblioteca de Autores Españoles, desde la formación del lenguaje hasta nuestros días. Tomo Segundo. Madrid: M. Rivadeneyra impresor - editor, 1858.

GRINSTEIN, Alexander. As normas de Freud para a interpretação dos sonhos. Tradução de Francisco M. da Rocha Filho. Rio de Janeiro: Imago, 1987. 260 p.

HAUSER, Arnold. História social da arte e da literatura. Tradução de Álvaro Cabral. São Paulo: Martins Fontes, 1995.

. Maneirismo - a crise da Renascença e o surgimento da arte moderna. $2^{\mathrm{a}}$ edição. São Paulo: Editora Perspectiva, 1993.

HORTA, Maria Teresa. Poesia completa 1967-1982. 2 vols. Lisboa: Litexa, 1983.

KAYSER, Wolfang. Análise e interpretação da obra literária. Tradução portuguesa de Paulo Quintela. 4a edição. Coimbra: Armênio Amado, 1967.

LOPE DE VEGA Y CARPIO, Felix. El palacio confuso. New York: Ediciones del Instituto de las Españas en los Estados Unidos, 1939.

LOURENÇO, Eduardo. "Camões-Actéon". In: . Poesia e metafísica. Lisboa: Sá da Costa Editora, 1983. 261 p.

MACEDO, Helder. "Sá de Miranda, Bernardim Ribeiro e a escola bernardiniana". In: Estudos portugueses/Homenagem a Luciana Stegagno Picchio. Lisboa: Difel, 1991. pp. 603-627. ISBN 972-29-0044-7.

. "Entre mim mesmo e mim ou o drama em gente de Bernardim Ribeiro". In: Encontro de Centros de Estudos Portugueses no Brasil, II, Anais. Rio de Janeiro: PUC-Rio, 1997.

MANRIQUE, Jorge. Coplas a la muerte de su padre. Madrid: Editorial ALBA, 1999. 92 p. ISBN 84-8336-024-1.

MARX, Karl. Manuscritos econômico-filosóficos e outros textos escolhidos. Seleção de textos de José Arthur Giannotti. Traduções de José Carlos Bruni... [et al.]. $5^{\mathrm{a}}$ ed. São Paulo: Nova Cultural, 1991. 272 p. ISBN 85-13-00226-7.

MIRANDA, Francisco de Sá de. Obras Completas. Volumes I e II. $4^{a}$ edição, revista. Texto fixado, notas e prefácio de Rodrigues Lapa. Lisboa: Livraria Sá da Costa Editora, 1976. $306 \mathrm{p}$.

MOLINA, Tirso de. "La Ventura con el nombre". In: Obras dramáticas completas Tomo IV. Madrid: Aguilar, 1989. 
OLIVEIRA FUNARO, Vânia M. B. de. (coord.) et al. Diretrizes para apresentação de dissertações e teses da USP: documento eletrônico e impresso. São Paulo: SIBi-USP, 2004. Universidade de São Paulo. Sistema Integrado de Bibliotecas. Grupo DiTeses. (Cadernos de Estudos; 9) 110 p. ISBN 85-7314-023-2.

O’NEILL, Alexandre. Poesias completas - 1951/1983. $2^{\text {a }}$ edição revista e aumentada. Lisboa: Biblioteca de Autores Portugueses - Imprensa Nacional - Casa da Moeda, 1984.

ORPHEU. Números $1 \& 2$. Provas de página do terceiro número. Edição facsimilada. $2^{\mathrm{a}}$ ed., Lisboa, Contexto, 1994.

PESSOA, Fernando. Obras completas de Fernando Pessoa vol. I - poesias de Fernando Pessoa. 11 $1^{\mathrm{a}}$ edição. Lisboa: Edições Ática, 1980. 269 p.

. Obras completas de Fernando Pessoa vol. VII - poesias inéditas (1930-1935) de

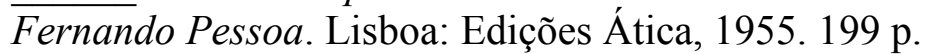

. Obras completas de Fernando Pessoa vol. VIII - poesias inéditas (1919-1930) de Fernando Pessoa. Lisboa: Edições Ática, 1956. 202 p.

. Obras completas de Fernando Pessoa vol. X-novas poesias inéditas de Fernando Pessoa. Lisboa: Edições Ática, 1979. 157 p.

PICO DELLA MIRANDOLA, Giovanni. Discurso sobre a dignidade do homem. Edição bilíngüe. Tradução de Maria de Lurdes Sirgado Ganho. Lisboa: Edições 70, 2006. 119 p. ISBN 972-44-1337-3.

PINA MARTINS, José V. de. "Sá de Miranda, um poeta para o nosso tempo". In: Estudos portugueses/Homenagem a Luciana Stegagno Picchio. Lisboa: Difel, 1991. pp. 1025-1045. ISBN 972-29-0044-7.

PLATÃO. Diálogos. São Paulo: Editora Cultrix, 1957. . A República. São Paulo: Difusão Européia do Livro, 1965.

PLAUTUS, Titus Maccius. Menaechmi. New York: Cambridge University Press, 1993. $290 \mathrm{p}$.

RIBEIRO, Bernardim. Obras poéticas de Bernardim Ribeiro. Edição revista e prefaciada por Delfim Guimarães. Lisboa: Livraria Editora Guimarães \& Ca 1930.223 p.

. Obras completas. Volume II - Éclogas. Prefácios e notas de Aquilino Ribeiro e M. Marques Braga. Lisboa: Livraria Sá da Costa - Editora, 1950. 235 p.

RIMBAUD, Arthur. Poesia completa. Edição bilíngüe, português e francês. Tradução, prefácio e notas de Ivo Barroso. Rio de Janeiro: Topbooks, 1995.

ROSENFELD, Anatol. "A teoria dos gêneros". In: O teatro épico. $4^{\mathrm{a}}$ edição. São Paulo: Editora Perspectiva, 2000. 176 p. 
RUEDA, Lope de. "Los engañados”. In: Teatro completo. Barcelona: Editorial Bruguera, 1979.

SÁ-CARNEIRO, Mário de. Obras completas de Mário de Sá-Carneiro Volume II Poesias. Lisboa: Edições Ática, 1978. 194 p.

SARAIVA, António José. Poesia e drama. Lisboa: Gradiva, 1990. 191 p. ISBN 972-662155-0.

SARDUY, Severo. Escrito sobre um corpo. Tradução de Lígia Chiappini Moraes Leite e Lúcia Teixeira Wisnik. São Paulo: Editora Perspectiva, 1979. 152 p.

SARTRE, Jean-Paul. O ser e o nada - Ensaio de ontologia fenomenológica. 15 ed., tradução de Paulo Perdigão. Petrópolis, RJ: Editora Vozes, 2007.782 p. ISBN 978-85-326$1762-0$.

. O existencialismo é um humanismo. Tradução de Rita Correia Guedes. In: Coleção Os Pensadores - Sartre. $3^{\text {a }}$ edição. São Paulo: Nova Cultural, 1987.

. A imaginação. Tradução de Luiz Roberto Salinas Fortes. In: Coleção Os Pensadores - Sartre. $3^{\mathrm{a}}$ edição. São Paulo: Nova Cultural, 1987.

SENA, Jorge de. Estudos de literatura portuguesa - I. Lisboa: Edições 70, 2001. 307 p. ISBN 972-44-1029-3.

SHAKESPEARE, William. The comedy of errors. London: Methuen \& Co. Ltd., 1962.

. "Twelfth night". In: . Four great comedies by William Shakespeare. New York: Pocket Books Inc., 1948.

TOMAS DE AQUINO. Suma Teologica. Texto latino de la edición crítica Leonina. Traducción y anotaciones por una comisión de PP. Dominicos presidida por el Excmo. y Rvdmo. Sr. Dr. Fr. Francisco Barbado Viejo, O. P., Obispo de Salamanca. Introducción General por el R. P. MTRO. Fr. Santiago Ramirez, O. P., Rector de la Facultad Teológica de PP. Dominicos de San Esteban y Profesor de la Universidad Pontificia de Salamanca. Madrid: Biblioteca de Autores Cristianos, 1960. 


\section{ANEXO}

\section{Francisco de Sá de Miranda:}

1

No sé por qué me fatigo, pues con razón me vencí, no siendo nadie conmigo y vos y yo contra mí.

Vos por m'haber desamado, yo por haberos querido, con vuestra fuerça y mi grado habemos a mí vencido; pues yo fui mi enemigo en darme como me dí, ¿quién osará ser amigo del enemigo de sí?

\section{GLOSA DE SÁ DE MIRANDA À CANTIGA PRECEDENTE, DE DOM JORGE MANRIQUE}

\section{2}

Del tormento fatigado no sé qué consejo sigo, voy de cuidado en cuidado; mas, después en mí tornado, no sé por qué me fatigo.

Haz lo que suele el pesar, desatinandome ansí; mas bolviendo a en vos pensar, no sé de qué me quexar, pues con razón me vencí.

En aquella mi agonía, ya no me quexo, mas digo: Quando fué la prisión mia, quién ayudarme podría 
no siendo nadie comigo?

Y aun esto no abastó, que harto mal era por sí: que a mí me faltase yo! No fuí comigo allí, no, y vos y yo contra mí!

Qué dirán a tal concierto, sin mas dilación cumplido? Entramos me havemos muerto: vos por qué no sé, mas, cierto, yo por haveros querido.

Lo más como lo sabré? Que en aquel punto ordenado que a vos los ojos alcé, a mí desamado me he, y vos a mí desamado.

En el mal, quando acontece, es consuelo el ser forzado; también esto aquí fallece: que juntamente parece con vuestra fuerza y mi grado.

Fuerza, en que no consentistes; mas vuestro poder sabido, en que venceis quanto vistes; él y los mis ojos tristes havemos a mí vencido.

Qué lágrimas y qué ruegos, alcanzarán un abrigo, en tantos desasosiegos, pues acendí los mis fuegos y pues fuí mi enemigo?

Es la razón natural, cada uno ansí por sí, que a los otros seré tal, quando a mí mismo hize mal en me dar como me dí?

Todos van al su provecho; yo, que a mis males me obligo, ando comigo en despecho; de tan duro y cruel pecho quien osará ser amigo? 
Mas, qué digo yo? Osará, y no mucho, antes ansí: qual peligro deterná aquel que fuyendo vá del enemigo de sí?

3

Señora, oíd la mi suerte y de vuestra crueldad: por no pediros piedad antes la pido a la muerte.

El mi corazón caído en tanta cuita y desmayo, pues que nunca os ha movido, ante la muerte lo trayo; mas no sé como concierte tan grande desigualdad, que me hazeis pedir piedad contra la muerte a la muerte.

4

Quanto mal me era ordenado: las cosas con que nací, algunas me han desechado, alcancé otras contra mí!

De la mi alma no sé que es della, y mi corazón; a la fuerza no hay razón, cad' uno tras vos se fué. Vida, memoria y cuidado, sentidos que a vos erguí, estos nunca me han dexado por seren más contra mí.

5

Que é isto? Onde me lançou esta tempestade má?

Qu'é de mi, se não sou lá, e cá comigo não vou? 
Inda que me eu cá não via, tudo vos confessarei: onde a vós e a mi deixei cuidava que me acharia; agora quem, donde estou, novas de mi me trará?

Pois dizeis que não sou lá, não sei sem mi onde vou.

\section{6}

Puédese esta llamar vida:

a la qual se entra llorando, que se pasa suspirando, la muerte es la su salida?

Por lo qual yo, sin ventura, con gran cuita, he deseado que huviera sido llevado del parto a la sepultura; tal esperanza perdida, yo no sé, loco, trás que ando; voyme así devaneando entre la muerte y la vida.

\section{7}

Mal, de que me eu contentei, contas, rematadas já, agora descansarei, esta dor me matará; se não... eu me matarei.

Nas cousas que não é meo é escusado cansar mais, ir de receo em receo e de sinais em sinais. Em vão cá e lá cansei, tudo me é tomado já; agora descansarei, ou me este mal matará; se não... eu me matarei. 
Comigo me desavim, sou posto em todo perigo; não posso viver comigo nem posso fugir de mim.

Com dor, da gente fugia, antes que esta assi crecesse; agora já fugiria de mim, se de mim pudesse. Que meo espero ou que fim do vão trabalho que sigo, pois que trago a mim comigo, tamanho imigo de mim?

Que mal avindos cuidados me tomaram antre si! Nunca tais cuidados vi.

A minha alma não repousa nem de noite, nem de dia; dentro nela contraria toda cousa a toda cousa; o cuidado, que mais ousa e que mais confia em si, ora é assi, e ora assi.

Que me quer este receo inda sobre meus agravos? Tem-me tomados os cabos, não tendo meus males meo. Já não confio nem creo, já confiei e já cri: mal assi, e mal assi.

Inda se isto ser pudesse: que, por tempo, se faria que ũa hora me não temesse, isto me descansaria.

Mas não vejo por que via se possa fazer, que assi não moura como vivi. 
de ver sua vaidade aquela cega vontade, que tam cegamente guia.

Que poderá um grande imigo fazer mais? Certo é que não; por mimos do coração inda tudo o pior sigo. Vou-me assi de dia em dia, olhos de longe à verdade; entretanto, esta vontade, assi cega, guia, guia.

\section{1}

Não vejo o rosto a ninguém; cuidais que são, e não são; homens, que não vão nem vem, parece que avante vão; antre o doente e o são mente cad'hora a espia; na meta do meo dia andais entre lobo e cão.

12

Deixai-me as minhas tristezas, que já'gora outra alegria maior perigo seria.

Aos males acostumados o mesmo costume é cura. Bens tam vãmente esperados, quem os sofre? E quem atura senão desapaixonados?

Criei-me com meus cuidados; já agora não saberia andar noutra companhia.

13

Toda esperança é perdida, tudo veo a falecer, e o que fica da vida, ficou para m'eu perder. 
Aquela esperança minha, assi falsa e vã como era, c'os olhos que eu nela tinha a todo mal me atrevera. Ora, ela é toda perdida; mas não m'hão de fazer crer que não há mais nesta vida senão nascer e morrer!

14

Como não quereis que seja meu perigo em todo extremo, se minha alma assi deseja tudo o de que me mais temo? E para mor meu tormento, assi cego, assi enlheado, de tudo o al fui roubado; ficou-me o conhecimento.

15

Ledo em meus males sem cura, e nos descansos cansado, querendo e sendo forçado, ora cuidar me assegura, ora me mata cuidado.

Assi me tem repartido extremos, que não entendo; de toda parte corrido, de todas desacorrido, de nenhũa me defendo. A vida está mal segura, eu tenho outro mor cuidado: que mal tam bem estimado, que nesta desaventura me faz bem aventurado! 
Ũa cousa cuidava eu

causa doutras muitas cousas;

razão tinha de a cuidar,

dá-me sem razão cuidado;

ind ei de pedir a outrem

das suas culpas perdão.

17

RÉPLICA DE D. LEONOR DE MASCARENHAS

Ũa cousa cuidava eu, que não sou para estas cousas:

razão fora não cuidar em tam sem razão cuidados, pois hei-de sofrer a outrem culpas que não tem perdão.

18

RÉPLICA DE BERNARDIM RIBEIRO

A mim me hei-de tornar eu, para vingar muitas cousas que não são para cuidar, foram para dar cuidado.

Seja minha a culpa d'outrem, que assi val mais que o perdão.

19

A ESTA CANTIGA ALHEIA

Ay, que el alma se me sale!

Lo porque siento perdella

es porque estais vos en ella,

que la vida poco vale.

Loco de mí que pensava

podella aquí detener

comigo: una alma que estava

ufana en vuestro poder! 
Qué quereis que a esto iguale, siendo vos señora d'ella? Esta es toda mi querella, que lo más todo, qué vale?

\section{0}

Fuye el tiempo, está el mal quedo, pensé morirme, y no muero; desengañarme no quiero; quando ya quiero, no puedo.

Todo se me va en antojos, en esta prisión escura: cuitados de los mis ojos que pagan tanta locura!

De todo me pide el miedo lágrimas como de fuero: de lo que puedo y no quiero, de lo que quiero y no puedo.

\section{1}

\section{A ESTE VILANCETE ALHEIO}

Quem cuidar e quem disser que de matar sois servida, não sabe que cousa é vida.

Não é dano o que não dana; té morte de vossa mão não é morte, é nome vão, que à primeira face engana. Onde não há cousa humana tudo spirito e tudo vida, mal jará a morte escondida.

Fica-se porém julgando antre ũa e a outra sorte; se dais vida dando a morte, que fareis a vida dando? A fé, que vai embicando, não vê dos olhos tal vida somente porque duvida. 
Polo bem, mal me quisestes!

E eu nunca tenha prazer

se vos mal posso querer!

For'ela razão igual!

Mas vede as leis que amor tem:

que em vez de vos querer mal, assi vos quero mor bem!

E passo tanto inda além do que este mal sói fazer, que me venho a aborrecer.

23

De quem me devo queixar?

De vós, que pudera ser, não vos sabe a alma culpar; fica somente o sofrer; se mais fica, é suspirar.

Os meus suspiros te agora quási eram contentamentos: também de prazer se chora; entraram males de fora, não um, não dous, mais seiscentos. Não lhes abastou entrar, mas inda sempre crecer: onde há-de ir isto a parar? Não fica senão sofrer ao mundo do suspirar.

Ora os suspiros que são salvo ar espalhado ao vento? Onde brada o coração, nossos ouvidos não vão, deixam tudo ao entendimento. Que m'eu quisesse queixar quem me poderia crer? Deixai, e venha o pesar. Que pode o pouco empecer? Que pode o muito durar? 
Alma tam sem assossego, que nem deste ar me não farto! Donde c'um queixume chego, com cem mil deles me parto.

Nas cousas em que algũa hora esperei de ter repouso, triste de mim, que já'gora somente cuidar não ouso! A que fraquezas que chego! Em quantas partes me parto por este coração cego, nunca de seus males farto!

Os meus perigos medonhos, em que a alma cad'hora empeça, os ventos, a névoa, os sonhos, que não tem pés, nem cabeça! O que co'a língua nego por muitos sinais reparto, em poder daquele cego de cujo poder não parto.

Mal as noites, mal os dias, com medos e com suspeitas, fazendo contas baldias, que asinha serão desfeitas! Com muito desassossego com que chego e com que parto, com ver tanto e ser tam cego, todos do que encubro farto!

Acostumei-me aos meus males; eu assi acostumado, e eles andam por me apartar deles.

Ah! que cruel tirania!

Não sei que nome lhe ponha: não me dói de ũa peçonha de que já'gora vivia; quando os meus males sentia, quando me queixava deles, lá me aviesse co eles. 
Despois que se ia mais brando fazendo o mal, por costume, viram-me andar sem queixume; matam-me, remédios dando. Tudo se vai revezando: males, que tremia ante eles, mouro de saudade deles!

\section{6}

Até quando me tereis nesta dor que por vós quis? Os serviços que vos fiz quando mos perdoareis? Não ser vosso não é em mim: isto quereis-mo acoimar? Que perdão posso esperar pera a alma, vossa sem fim? Se me tanto mal fazeis por serviços que vos fiz, o bem que vos quero e quis quando mo perdoareis?

A ESTE VILANCETE ALHEIO

No pregunteis a mis males que tales son.

Preguntaldo al corazón!

Por mis bienes preguntais, entiendo que por mis penas, que siempre tuve por buenas. Vos ved como las llamais, que ansí como las nombrais, ansí confieso que son los bienes del corazón.

Ay, qué vida tan esquiva! dó, por enemiga suerte, 
por lloro y dolor se arriva, dó se bive en pena biva, y se sale por la muerte.

Por dó yo, desventurado, que juzgo mi desventura, con deseo he deseado que huviera sido llevado del vientre a la sepultura.

Ca la mi alma cativa, do quiera que se convierte, cercada de pena esquiva, no ve por donde reciba menos mal que por la muerte.

29

Antre temor e desejo, vã esperança e vã dor, antre amor e desamor meu triste coração vejo.

Nestes estremos, cativo ando, sem fazer mudança; e já vivi d'esperança e agora de choro vivo. Contra mi mesmo pelejo, vem d'ũa dor outra dor e dum desejo maior nace outro moor desejo.

Yo no la entiendo bien, mas esta fuente habla comigo; y horas se m'antoja como de tantas quexas, que se enoja, horas que me consuela y que las siente.

Trúxome aquí un cuidado, y no consiente que me vaya a otra parte y que m'acoja de los sueños en que ando, juzgue, escoja. Ya vergüenza es tardar tan luengamente.

Gran fuerza se m'ha hecho a los mis ojos, grande al entendimiento, andando así de veras ocupado en mis antojos. 
No sé lo que me ví, ni que no ví, quien puso tal sabor en mis enojos, apesar (que es peor) tanto de mí.

\section{1}

Em tormentos cruéis, tal sofrimento, em tam contínua dor, que nunca aliva, chamar a morte sempre, e que ela, altiva, se ria dos meus rogos, no tormento!

E ver no mal que todo entendimento naturalmente foge, e quanto aviva a dor mais o vagar da alma cativa, a quem não fará crer que é tudo um vento?

Bem sei uns olhos, que tem toda a culpa, e são os meus, que a toda a parte vem após o que vêm sempre e os desculpa.

Ó minhas visões altas, meu só bem, quem vos a vós não vê, esse me culpa, e eu sou o só que as vejo, outrem ninguém!

32

Desarrezoado amor, dentro em meu peito, tem guerra com a razão. Amor, que jaz i já de muitos dias, manda e faz tudo o que quer, a torto e a direito.

Não espera razões, tudo é despeito, tudo soberba e força; faz, desfaz, sem respeito nenhum; e quando em paz cuidais que sois, então tudo é desfeito.

Doutra parte, a Razão tempos espia, espia ocasiões de tarde em tarde, que ajunta o tempo; em fim, vem o seu dia:

Então não tem lugar certo onde aguarde Amor; trata treições, que não confia nem dos seus. Que farei quando tudo arde? 


\section{Bernardim Ribeiro:}

1

Que forte fortuna sigo, a que grande extremo vim, que já não vejo perigo para mim maior que mim!

Tudo soube recear que era bem que receasse; quem havia de cuidar que de mim eu me guardasse? Não me guardei como devo, e vim ter a o que vim, que já não vejo perigo para mim maior que mim.

2

Senhora, pois não deixais a minha vida viver, já agora não peço mais que deixarde-la morrer.

Porque morra cada hora, não me acabais de matar, e, por me mais magoar, quando me matais, senhora, não dais à morte lugar; a vida vós a matais, pois a não deixais viver; assim que não peço mais que deixarde-la morrer.

3

Nada quero, tudo enjeito, o maior bem me aborrece, o prazer me entristece, e o viver, porque é sujeito a quem dele assim se esquece; se morro, acaba o mal, e fim não queria ver; 
se vivo, o padecer

desta dor é tam mortal

que me não posso valer.

4

Entre mim mesmo e mim não sei que se levantou, que tam meu imigo sou.

Uns tempos com grande engano vivi eu mesmo comigo; agora no maior perigo se me descobriu mor dano. Caro custa um desengano, e, pois me êste matou, assás caro me custou.

De mim sou feito alheio; entre cuidado e cuidado, está um mal derramado, que por meu gram mal me veio; nova dor, novo receio, foi êste que me tomou, que tam meu imigo sou.

5

Menina, pois sois formosa, não sejais despiedosa!

Que não parece razão, tendo tanta perfeição, que tenhais a condição tam esquiva e desdenhosa; não sejais despiedosa.

Por vós, de mim esquecido, ando tam triste e perdido, que tomara por partido não vos ver ser tam formosa; vira-vos mais piedosa.

Não sei já como vos veja, que para meu mal não seja; se rides, matais de inveja; se, por acaso, estais irosa, 
sois muito mais perigosa.

6

Ao cabo de tantos anos, quando cuidei descansar, em galardão de meus danos, querem-me desenganar. Pude com meu mal 'té'qui, de meu engano ajudado; agora, triste de mi, que farei, desenganado?

Se lembranças me deixaram, pudera eu meu mal deixar; se cousas se não mudaram, descanso fôra cuidar. Pois tudo se muda assi, e eu não sei ser só mudado, tamanha perda perdi em perder-se-me o cuidado!

Todo o bem dura um momento, e o mal é de todo o ano; por breve contentamento: grande tempo grande engano. Foi-se o engano e deixou o mal da vida que sigo; assim que quem me matou trago eu sempre comigo.

Um cuidado que eu plantei de que agora colho o dano! tudo o que tinha empreguei, e levou-mo um desengano; e, porque do meu tormento, mais que de mim, fui amigo, por salvar um pensamento fiquei eu só no perigo.

Fico assi esperando a fim que meu mal me quiser dar, que passou já para mim todo o tempo de folgar. Mas, pois assim foi servida quem mo só pode ter dado, esperar mais nesta vida para mim é escusado. 
Minhas justas esperanças derramou-mas um pesar; eu não cuido nas mudanças, cansado estou de cuidar. Neste mal tam sem conforto d'isto só sou consolado:

- que muito há que sou morto da parte de meu cuidado.

\section{7}

Entre tamanhas mudanças, que cousa terei segura? duvidosas esperanças, tam certa desaventura!

Venham êstes desenganos do meu longo engano, e vão, que já os tempos e os anos outros cuidados me dão. Já não sou para mudanças, mais quero uma dor segura; vá crer as vãs esperanças quem não sabe o que aventura!

\section{8}

De esperança em esperança, pouco a pouco me levou grande engano ou confiança, que me tam longe deixou. Se me isto tomara outrora, cuidara de ver-lhe fim; mas que hei de cuidar já'gora, sem esperança e sem mim?

\section{9}

Cuidados, assim vos quero; que sejais desesperados, quero-vos para cuidados.

Tempo foi, que nunca fôra, quando com outra esperança 
tôda minha confiança

pus em vós só por uma hora.

Muito mais vos quero agora, porque sois desesperados; quero-vos para cuidados.

Não vos quero por vã-glória de ter-vos, ainda que a tenho comigo, que só vos tenho, de mi a mim só faço história; pus-vos na minha memória, donde nunca outros cuidados foram tam desesperados.

Cuidados, assim vos quero; o que tenho dou a vós sós; desesperados sois vós, eu sou o que desespero; vinde, que assim vos espero; quanto mais desesperados, quero-vos para cuidados.

Coitado! Quem me dará novas de mim? Onde estou, pois dizeis que não sou lá, e cá comigo não vou?

Todo êste tempo, senhora, sempre por vós preguntei, mas que farei, que já agora de vós nem de mim não sei? Olhe vossa mercê lá se me tem, se me matou, porque eu vos juro que cá morto nem vivo não vou.

11

Comigo me desavim, vejo-me em grande perigo; não posso viver comigo, nem posso fugir de mim.

Antes que êste mal tivesse, da outra gente fugia; 
agora, já fugiria

de mim, se de mim pudesse.

Que cabo espero ou que fim

dêste cuidado que sigo,

pois trago a mim comigo

tamanho imigo de mim?

12

Para tudo houve remédio, para mim só o não houve aí, inda mal que o soube assi!

Fogem as vacas para a água porque a mosca as vai seguir; eu só, triste em minha mágoa, não tenho onde fugir; daqui me não posso eu ir, estar não me cumpre aqui, que o que eu quero não no há 'i.

Entretanto a calma dura, tem esta fadiga o gado: a manhã pasce em verdura, a tarde em o sêco prado; dorme a noite sem cuidado, que tudo olhou para si; descanso eu só o perdi.

A mim, nem quando o soi sai, nem depois que se vai pôr, nem quando a calma mor cai, não me deixa minha dor. Dor, e outra cousa maior, convosco hoje amanheci, convosco onte'anoiteci.

Crendo que assi acabaria dei-me todo ao que padeço: um dia leva outro dia, por um mal outro conheço. Se o fim responde ao comêço, ai! quam mal que me provi, que no comêço o fím vi!

Se nasci por meu mal ver, e não por vê-lo acabado, melhor fôra não nascer, 
que ver-me desesperado.

E pois que êste meu cuidado

me traz tam cego após si,

inda mal que o soube assi!

Entre lágrimas e pranto, nasceu o meu pensamento; cresceu, em tam pouco, tanto que é mais alto que o tormento! Passa o que passo ao que sento. Mal faz quem me esquece assi, que após mim não há outro mi.

Vai-se tanto prolongando o fim do que eu espero, que a vida me vai gastando, pois já dela desespero. Fortuna me vai guiando contrária sempre de si; nem sei para que nasci!

\section{Luís de Camões:}

\section{1 \\ MOTE ALHEIO}

De dentro tengo mi mal, que de fuera no hay señal.

\section{VOLTA}

Mi nueva y dulce querella es invisible á la gente: el alma sola la siente, que el cuerpo no es dino della. Como la viva centella se encubre en el pedernal, de dentro tengo mi mal. 


\section{MOTE}

De que me serve fugir de morte, dor e perigo, se me eu levo comigo?

\section{VOLTAS}

Tenho-me persuadido, por razão conveniente, que não posso ser contente, pois que pude ser nacido. Anda sempre tão unido o meu tormento comigo que eu mesmo sou meu perigo.

E se de mi me livrasse, nenhum gosto me seria; que, não sendo eu, não teria mal que esse bem me tirasse. Força é logo que assi passe: ou com desgosto comigo, ou sem gosto e sem perigo.

A dona Francisca de Aragão, mando-lhe esta regra que lha glosasse.

Mas porém a que cuidados?

\section{PRIMEIRA GLOSA}

Tanto maiores tormentos foram sempre os que sofri daquilo que cabe em mi, que não sei que pensamentos são os para que naci.

Quando vejo este meu peito a perigos arriscados inclinado, bem suspeito que a cuidados sou sujeito: mas porém a que cuidados? 
Que vindes em mi buscar, cuidados, que sou cativo e não tenho que vos dar? Se vindes a me matar, já há muito que não vivo; se vindes, porque me dais tormentos desesperados, eu, que sempre sofri mais, não digo que não venhais: mas porém a quê, cuidados?

\section{TERCEIRA GLOSA}

Se as penas que Amor me deu vêm por tão suaves meios, não há que temer receios, que val um cuidado meu por mil descansos alheios. Ter nuns olhos tão fermosos os sentidos enlevados bem sei que, em baixos estados, são cuidados perigosos.

Mas porém, ah! que cuidados!

\section{CARTA MANDADA COM ESTAS GLOSAS}

Deixei-me enterrar no esquecimento de V. M., crendo que me seria assi mais seguro; mas agora que é servida de me tornar a ressuscitar, por me mostrar seus poderes, lembro-lhe que ũa vida trabalhosa é menos de agradecer que ũa morte descansada. Mas se esta vida, que agora de novo me dá, for para ma tornar a tomar, servindo-se dela, não me fica mais que desejar que poder acertar com este mote de V. M., ao qual dei três entendimentos, segundo as palavras dele puderam sofrer. Se forem bons, é mote de V. M.; se maus, são as glosas minhas.

\section{4 MOTE ALHEIO}

Triste vida se me ordena, pois quer vossa condição que os males, que dais por pena, me fiquem por galardão.

\section{GLOSA}


Depois de sempre sofrer, senhora, vossas cruezas, apesar de meu querer, me quereis satisfazer meus serviços com tristezas. Mas pois embalde resiste quem vossa vida condena, prestes estou para a pena; que, de galardão tão triste, triste vida se me ordena.

De contente do mal meu, a tão grande extremo vim que consinto em minha fim; assi que, vós e mais eu, ambos somos contra mim. Mas que sofra meu tormento sem querer mais galardão, não é fora de razão que queira meu sofrimento, pois quer vossa condição.

O mal que vós dais por bem, esse, Senhora, é mortal; que o mal que dais como mal, em muito menos se tem, por costume natural.

Mas porém nesta vitória, que comigo é bem pequena, a maior dor me condena a pena, que dais por glória, que os males, que dais por pena.

Que mór bem me possa vir que servir-vos, não o sei. Pois que mais quero eu pedir se, quanto mais vos servir, tanto mais vos deverei? Se vossos merecimentos de tão alta estima são, assaz de favor me dão em querer que meus tormentos me fiquem por galardão. 
Amor loco, amor loco,

yo por vos y vos por otro.

\section{VOLTAS}

Dióme Amor tormentos dos para que pene doblado: uno es verme desamado, otro es mancilla de vos. Ved que ordena Amor en nos: porque me vos hacéis loco, que seáis loca por otro!

Tratáis Amor de manera que porque así me tratáis quiere que, pues no me amáis, que améis otro que no os quiera. Mas con todo, si no os viera de todo loca por otro, con mas razón fuera loco.

Y tan contrario viviendo, alfin, alfin, conformamos, pues ambos a dos buscamos lo que más nos va huyendo. Voy tras vos siempre siguiendo, y vos huyendo por otro: andáis loca, y me hacéis loco.

\section{6 MOTE ALHEIO}

Vede bem se nos meus dias os desgostos vi sobejos, pois tenho medo a desejos e quero mal a alegrias.

\section{VOLTA}

Se desejos fui já ter, serviram de atormentar-me; se algum bem pôde alegrar-me, quis-me antes entristecer. Passei anos, passei dias, em desgostos tão sobejos 
que, só por não ter desejos, perderei mil alegrias.

Mote que Ihe mandou o vizo-rei, na Índia, pera Ihe fazer ũas voltas

Muito sou meu inimigo, pois que não tiro de mi cuidados com que naci, que poem a vida em perigo. Oxalá que fora assi!

\section{VOLTAS}

Viver eu, sendo mortal, de cuidados rodeado, parece meu natural, que a peçonha não faz mal a quem foi nela criado. Tanto sou meu inimigo que, por não tirar de mi cuidados com que naci, porei a vida em perigo. Oxalá que fora assi!

Tanto vim a acrecentar Cuidados, que nunca amansam enquanto a vida durar, que canso já de cuidar como cuidados não cansam. Se estes cuidados que digo dessem fim a mi e a si, fariam pazes comigo; que pôr a vida em perigo o bom fora para mi. 
Já 'gora certo conheço ser milhor todo tormento onde o arrependimento se compra por justo preço. Enganou-me um bom começo; mas o fim me diz agora que o mal milhor me fora.

Quando um bem é tão danoso que, sendo bem, dá cuidado, o dano fica obrigado a ser menos perigoso. Mas se a mim, por desditoso, co bem me foi mal, Senhora, co vosso mal bem me fora.

9

A ũas senhoras que haviam de ser terceiras para com ũa dama sua.

Pois a tantas perdições,

Senhoras, quereis dar vida, ditosa seja a ferida que tem tais cerurgiões!

Pois ventura

me subiu a tanta altura

que me sejais valedoras, ditosa seja a tristura que se cura

por vossos rogos, Senhoras!

Ser minha pena mortal, já qu' entendeis que é assim, não quero falar por mim, que por mim fala meu mal. Sois fermosas:

haveis de ser piadosas, por ser tudo dũa cor; que pois Amor vos fez rosas milagrosas, fazei milagres d' amor.

Pedi a quem vós sabeis que saiba de meu trabalho, não pelo que eu nisso valho, mas pelo que vós valeis. 
Que o valer

de vosso alto merecer, com lho pedir de giolhos, fará que em meu padecer possa ver o poder que têm seus olhos.

Vossa muita fermosura co a sua tanto val que me rio de meu mal quando cuido em quem mo cura. A meus ais peço-vos que lhe valhais, Damas de Amor tão validas, que nunca tal dor sintais, que queirais

onde não sejais queridas.

Esparsa sua ao desconcerto do mundo

Os bons vi sempre passar no mundo graves tormentos; e, para mais m' espantar, os maus vi sempre nadar em mar de contentamentos. Cuidando alcançar assim o bem tão mal ordenado, fui mau; mas fui castigado. Assim que só para mim anda o mundo concertado.

\section{1 VILANCETE PASTORIL}

- Deus te salve, Vasco amigo!

Não me falas? Como assi?

- Bofé, Gil, não estava aqui...

\section{VOLTAS}

- Pois onde te vão falar, se não estás onde apareces? 
- Se Madanela conheces, nela me podes achar.

- E como te hã-de ir buscar aonde fogem de ti?

- Pois nem eu estou em mi...

- Porque te não acharei em ti, como em Madanela? - Porque me fui perder nela o dia que me ganhei.

- Quem tão bem fala, não sei como anda fora de si.

- Ela fala dentro em mi.

- Como estás aqui presente, se lá tens a alma e a vida?

- Porque é de ũa alma perdida aparecer sempre à gente.

- Se és morto, bem se consente que todos fujam de ti.

- Eu também fujo de mi.

\section{MOTE}

Ferro, fogo, frio e calma todo o mundo acabarão; mas nunca vos tirarão, alma minha, da minha alma.

\section{VOLTA}

Não vos guardei, quando vinha, em torre, força ou engenho; que mais guardada vos tenho em vós, que sois alma minha. Ali, nem frio nem calma não podem ter jurdição; na vida sim, porém não em vós, que tenho por alma. 
Sem vós, e com meu cuidado

Olhai com quem - e sem quem!

\section{GLOSA}

Vendo Amor que, com vos ver,

Mais levemente sofria

Os males que me fazia,

Não me pôde isto sofrer;

Conjurou-se com meu Fado,

Um novo mal me ordenou:

Ambos me levam forçado

Não sei onde, pois que vou

Sem vós - e com meu cuidado:

Não sei qual é mais estranho

Destes dois males que sigo:

Se não vos ver, se comigo

Levar o imigo tamanho.

$\mathrm{O}$ que fica e o que vem,

Um me mata, outro desejo;

Com tal mal e sem tal bem,

Em tais extremos me vejo:

Olhai com quem - e sem quem!

(Edição de Hernani Cidade)

\section{4 \\ AO MESMO MOTE}

\section{MOTE ALHEIO}

Sem vós e com meu cuidado,

olhai com quem e sem quem.

\section{GLOSA}

Amor, cuja providência

foi sempre que não errasse

por que n' alma vos levasse,

respeitando o mal - de ausência,

quis que em vós me transformasse.

E vendo-me ir maltratado,

eu e meu cuidado sós,

proveio nisso, de atentado, 
por não me ausentar de vós, sem vós e com meu cuidado.

Mas est' alma que eu trazia porque vós nela morais, deixa-me cego e sem guia, que há por milhor companhia ficar onde vós ficais. Assi me vou de meu bem onde quer a forte estrela, sem a alma, que em si vos tem, co mal de viver sem ela: olhai com quem, e sem quem.

\section{5}

\section{MOTE}

Ojos, herido me habéis, acabad ya de matarme; mas, muerto, volved á mirarme por que me resucitéis.

\section{VOLTAS}

Pues me distes tal herida con gana de darme muerte, el morir me es dulce suerte, pues con morir me dais vida. Ojos, qué os detenéis? acabad ya de matarme; mas muerto volved á mirarme, por que me resucitéis.

La llaga cierto ya es mía, aunque, ojos, vos no queráis; mas si la muerte me dais, el morir me es alegría. Y así digo que acabéis, ojos, ya de matarme; mas muerto, volved á mirarme, por que me resucitéis. 
Retrato, vós não sois meu. Retrataram-vos mui mal:

que, a serdes meu natural, fôreis mofino como eu.

\section{GLOSA}

Inda que em vós a arte vença o que o natural tem dado, não fostes bem retratado, que há em vós mais diferença que do vivo ao pintado.

Se o lugar se considera do alto estado que vos deu a sorte, que eu mais quisera, se é que eu sou quem de antes era, retrato, vós não sois meu.

Vós na vossa glória posto, eu na minha sepultura; vós com bens, eu com desgosto; parecei-vos ao meu rosto, e não já à minha ventura. E pois nela e vós erraram o que em mim é principal, muito em ambos se enganaram. Se por mim vos retrataram, retrataram-vos mui mal.

Mas se esse rosto fingido quiseram representar, e houveram por bom partido dar-vos a alma do sentido pera a glória do lugar, víreis, posto nessa alteza, que em vós não há cousa igual, e que nem a maior mal podeis vir, nem por baixeza, que a serdes meu natural.

Por isso não confesseis serdes meu, que é desatino com que o lugar perdereis. Se conservar-vos quereis, blazonai que sois divino; que, se nesta ocasião conhecessem que éreis meu, 
por meu vos deram de mão,

fôreis mofino, como eu.

\section{7}

MOTE

A alma que está of'recida

a tudo, nada lhe é forte;

assi passa o bem da vida

como passa o mal da morte.

\section{VOLTA}

De maneira me sucede o que temo e o que desejo, que sempre o que temo vejo, nunca o que a vontade pede. Tenho tão oferecida alma e vida a toda a sorte que isso me dera da morte como já me dá da vida.

\section{8}

MOTE

No meu peito o meu desejo da razão se fez tirano; vejo nele certo dano, incerto remédio vejo.

\section{VOLTA}

Pera de todo defender-me, este mal por passar tinha: ir eu contra a razão minha que morre por defender-me. Da parte de meu desejo me passo pera meu dano; vejo que nisto me engano, mas nenhum remédio vejo. 
19

Transforma-se o amador na cousa amada, por virtude do muito imaginar; não tenho, logo, mais que desejar, pois em mim tenho a parte desejada.

Se nela está minh' alma transformada, que mais deseja o corpo de alcançar? Em si somente pode descansar, pois consigo tal alma está liada.

Mas esta linda e pura semideia que, como um acidente em seu sujeito, assi com a alma minha se conforma,

está no pensamento como idéia:

o vivo e puro amor de que sou feito, como a matéria simples, busca a forma.

\section{0}

Tanto de meu estado me acho incerto que, em vivo ardor, tremendo estou de frio; sem causa, juntamente choro e rio; o mundo todo abarco e nada aperto.

É tudo quanto sinto um desconcerto; da alma um fogo me sai, da vista um rio; agora espero, agora desconfio, agora desvario, agora acerto.

Estando em terra, chego ao Céu voando; Num' hora acho mil anos, e é de jeito que em mil anos não posso achar um' hora.

Se me pergunta alguém porque assi ando, respondo que não sei; porém suspeito que só porque vos vi, minha Senhora.

21

Como quando do mar tempestuoso o marinheiro, lasso e trabalhado, de um naufrágio cruel já salvo a nado, só o ouvir falar nele o faz medroso, 
e jura que, em que veja bonançoso

o violento mar e sossegado,

não entre nele mais, mas vai, forçado

pelo muito interesse cobiçoso;

assi, Senhora, eu, que da tormenta de vossa vista fujo, por salvar-me, jurando de não mais em outra ver-me:

minha alma, que de vós nunca se ausenta, dá-me por preço ver-vos, faz tornar-me donde fugi tão perto de perder-me.

22

Sempre a Razão vencida foi de Amor; mas, porque assi o pedia o coração, quis Amor ser vencido da Razão. Ora que caso pode haver maior!

Novo modo de morte e nova dor! Estranheza de grande admiração: que perde suas forças a afeição, por que não perca a pena o seu rigor.

Pois nunca houve fraqueza no querer, mas antes muito mais se esforça assim um contrário com outro, por vencer.

Mas a Razão, que a luta vence, enfim, não creio que é razão; mas há-de ser inclinação que eu tenho contra mim.

23

O dia em que eu naci moura e peraça, não o queira jamais o tempo dar; não torne mais ao mundo e, se tornar, eclipse nesse passo o Sol padeça.

A luz lhe falte, o Sol se lhe escureça, mostre o mundo sinais de se acabar; naçam-lhe monstros, sangue chova o ar, a mãe ao próprio filho não conheça.

As pessoas pasmadas, de ignorantes, 
as lágrimas no rosto, a côr perdida, cuidem que o mundo já se destruiu.

Ó gente temerosa, não te espantes, que este dia deitou ao mundo a vida mais desventurada que se viu!

\section{Mário de Sá-Carneiro:}

\section{ESCAVAÇÃO}

Numa ânsia de ter alguma cousa, Divago por mim mesmo a procurar, Desço-me todo, em vão, sem nada achar, E minh'alma perdida não repousa.

Nada tendo, decido-me a criar:

Brando a espada: sou luz harmoniosa

E chama genial que tudo ousa

Unicamente à força de sonhar...

Mas a vitória fulva esvai-se logo...

E cinzas, cinzas só, em vez de fogo...

- Onde existo que não existo em mim?

Um cemitério falso sem ossadas, Noites d'amor sem bocas esmagadas -

Tudo outro espasmo que princípio ou fim...

ÁLCOOL

Guilhotinas, pelouros e castelos

Resvalam longemente em procissão;

Volteiam-me crepúsculos amarelos,

Mordidos, doentios de roxidão.

Batem asas de auréola aos meus ouvidos, Grifam-me sons de cor e de perfumes, 
Ferem-me os olhos turbilhões de gumes, Descem-me a alma, sangram-me os sentidos.

Respiro-me no ar que ao longe vem, Da luz que me ilumina participo;

Quero reunir-me, e todo me dissipo -

Luto, estrebucho... Em vão! Silvo para além...

Corro em volta de mim sem me encontrar...

Tudo oscila e se abate como espuma...

Um disco de oiro surge a voltear...

Fecho os meus olhos com pavor da bruma...

Que droga foi a que me inoculei?

Ópio de inferno em vez de paraíso?...

Que sortilégio a mim próprio lancei?

Como é que em dor genial eu me eternizo?

Nem ópio nem morfina. O que me ardeu,

Foi álcool mais raro e penetrante:

É só de mim que ando delirante -

Manhã tão forte que me anoiteceu.

\section{DISPERSÃO}

Perdi-me dentro de mim

Porque eu era labirinto,

E hoje, quando me sinto,

É com saudades de mim.

Passei pela minha vida

Um astro doido a sonhar.

$\mathrm{Na}$ ânsia de ultrapassar,

Nem dei pela minha vida...

Para mim é sempre ontem,

Não tenho amanhã nem hoje:

O tempo que aos outros foge

Cai sobre mim feito ontem.

(O Domingo de Paris

Lembra-me o desaparecido

Que sentia comovido

Os Domingos de Paris:

Porque um domingo é família, 
É bem-estar, é singeleza,

E os que olham a beleza

Não têm bem-estar nem família)

O pobre moço das ânsias...

Tu, sim, tu eras alguém!

E foi por isso também

Que te abismaste nas ânsias.

A grande ave doirada

Bateu asas para os céus,

Mas fechou-as saciada

Ao ver que ganhava os céus.

Como se chora um amante,

Assim me choro a mim mesmo:

Eu fui amante inconstante

Que se traiu a si mesmo.

Não sinto o espaço que encerro

Nem as linhas que projecto:

Se me olho a um espelho, erro -

Não me acho no que projecto.

Regresso dentro de mim

Mas nada me fala, nada!

Tenho a alma amortalhada.

Sequinha, dentro de mim.

Não perdi a minha alma, Fiquei com ela, perdida.

Assim eu choro, da vida,

A morte da minha alma.

Saudosamente recordo

Uma gentil companheira

Que na minha vida inteira

Eu nunca vi... mas recordo

A sua boca doirada

E o seu corpo esmaecido,

Em um hálito perdido

Que vem na tarde doirada.

(As minhas grandes saudades São do que nunca enlacei.

Ai, como eu tenho saudades

Dos sonhos que não sonhei!...) 
E sinto que a minha morte -

Minha dispersão total -

Existe lá longe, ao norte,

Numa grande capital.

Vejo o meu último dia

Pintado em rolos de fumo,

E todo azul-de-agonia

Em sombra e além me sumo.

Ternura feita saudade,

Eu beijo as minhas mãos brancas...

Sou amor e piedade

Em face dessas mãos brancas...

Tristes mãos longas e lindas

Que eram feitas pra se dar...

Ninguém mas quis apertar...

Tristes mãos longas e lindas...

Eu tenho pena de mim,

Pobre menino ideal...

Que me faltou afinal?

Um elo? Um rastro?... Ai de mim!...

Desceu-me n'alma o crepúsculo;

Eu fui alguém que passou.

Serei, mas já não me sou;

Não vivo, durmo o crepúsculo.

Álcool dum sono outonal

Me penetrou vagamente

A difundir-me dormente

Em uma bruma outonal.

Perdi a morte e a vida,

$\mathrm{E}$, louco, não enlouqueço...

A hora foge vivida

Eu sigo-a, mas permaneço...

Castelos desmantelados,

Leões alados sem juba... 
Olho em volta de mim. Todos possuem Um afecto, um sorriso ou um abraço.

Só para mim as ânsias se diluem

E não possuo mesmo quando enlaço.

Roça por mim, em longe, a teoria

Dos espasmos golfados ruivamente;

São êxtases da cor que eu fremiria,

Mas a minh'alma pára e não os sente!

Quero sentir. Não sei... perco-me todo...

Não posso afeiçoar-me nem ser eu:

Falta-me egoísmo para ascender ao céu,

Falta-me unção para me afundar no lodo.

Não sou amigo de ninguém. Para o ser

Forçoso me era antes possuir

Quem eu estimasse - ou homem ou mulher, E eu não logro nunca possuir!...

Castrado de alma e sem saber fixar-me, Tarde a tarde na minha dor me afundo... Serei um emigrado doutro mundo

Que nem na minha dor posso encontrar-me?

Como eu desejo a que ali vai na rua,

Tão ágil, tão agreste, tão de amor...

Como eu quisera emaranhá-la nua,

Bebê-la em espasmos de harmonia e cor!...

Desejo errado... Se a tivera um dia,

Toda sem véus, a carne estilizada

Sob o meu corpo arfando transbordada,

Nem mesmo assim - ó ânsia! - eu a teria...

Eu vibraria só agonizante

Sobre o seu corpo de êxtases doirados, Se fosse aqueles seios transtornados, Se fosse aquele sexo aglutinante...

De embate ao meu amor todo me ruo, E vejo-me em destroço até vencendo: É que eu teria só, sentindo e sendo Aquilo que estrebucho e não possuo.

\section{ALÉM-TÉDIO}


Nada me expira já, nada me vive -

Nem a tristeza nem as horas belas.

De as não ter e de nunca vir a tê-las,

Fartam-me até as coisas que não tive.

Como eu quisera, enfim de alma esquecida,

Dormir em paz num leito de hospital...

Cansei dentro de mim, cansei a vida

De tanto a divagar em luz irreal.

Outrora imaginei escalar os céus

À força de ambição e nostalgia,

E doente-de-Novo, fui-me Deus

No grande rastro fulvo que me ardia.

Parti. Mas logo regressei à dor,

Pois tudo me ruiu... Tudo era igual:

A quimera, cingida, era real,

A própria maravilha tinha cor!

Ecoando-me em silêncio, a noite escura

Baixou-me assim na queda sem remédio;

Eu próprio me traguei na profundura,

Me sequei todo, endureci de tédio.

E só me resta hoje uma alegria:

É que, de tão iguais e tão vazios,

Os instantes me esvoam dia a dia

Cada vez mais velozes, mais esguios...

\section{A QUEDA}

E eu que sou o rei de toda esta incoerência, Eu próprio turbilhão, anseio por fixá-la E giro até partir... Mas tudo me resvala Em bruma e sonolência.

Se acaso em minhas mãos fica um pedaço de oiro, Volve-se logo falso... ao longe o arremesso...

Eu morro de desdém em frente dum tesoiro, Morro à míngua, de excesso.

Alteio-me na cor à força de quebranto, Estendo os braços de alma - e nem um espasmo venço!... 
Peneiro-me na sombra - em nada me condenso... Agonias de luz eu vibro ainda entanto.

Não me pude vencer, mas posso-me esmagar,

- Vencer às vezes é o mesmo que tombarE como inda sou luz, num grande retrocesso, Em raivas ideais ascendo até ao fim:

Olho do alto o gelo, ao gelo me arremesso...

Tombei...

E fico só esmagado sobre mim!...

\section{EPÍGRAFE}

A sala do castelo é deserta e espelhada.

Tenho medo de Mim. Quem sou? De onde cheguei?... Aqui, tudo já foi... Em sombra estilizada, A cor morreu - e até o ar é uma ruína...

Vem de Outro tempo a luz que me ilumina Um som opaco me dilui em Rei...

\section{NÃO}

Longes se aglomeram

Em torno aos meus sentidos, Nos quais prevejo erguidos

Paços reais de mistérios.

Cinjo-me de cor, E parto a demandar.

Tudo é Oiro em meu rastro -

Poeira de amor...

Adivinho alabastro...

Detenho-me em luar...

Lá se ergue o castelo

Amarelo do medo

Que eu tinha previsto: 
As portas abertas.

Lacaios parados,

As luzes, desertas -

Janelas incertas,

Torreões sepulcrados...

Vitória! Vitória!

Mistério é riqueza -

E o medo é Mistério!...

Ó paços reais encantados

Dos meus sentidos doirados,

Minha glória, minha beleza!

(- Se tudo quanto é doirado

Fosse sempre um cemitério?...)

Heráldico de Mim,

Transponho liturgias...

Arrojo-me a entrar

Nos Paços que alteei.

Quero depor o Rei

Para lá me coroar.

Ninguém me veda a entrada,

Ascendo a Escadaria -

Tudo é sombra parada,

Silêncio, luz fria...

Ruiva, a sala do trono

Ecoa roxa aos meus passos.

Sonho os degraus do trono -

E o trono cai feito em pedaços...

Deixo a sala imperial,

Corro nas galerias,

Debruço-me às gelosias -

Nenhuma deita pra jardins...

Os espelhos são cisternas -

Os candelabros

Estão todos quebrados...

Vagueio o Palácio inteiro,

Chego ao fim dos salões...

Enfim, oscilo alguém!

Encontro uma Rainha,

Velha, entrevadinha, 
A que vigiam dragões...

E acordo...

Choro por mim... Como fui louco...

Afinal

Neste Palácio Real

Que os meus sentidos ergueram.

$\mathrm{Ai}$, as cores nunca viveram...

Morre só uma Rainha,

Entrevada, sequinha,

Embora a guardem dragões...

- A Rainha velha é a minha Alma - exangue...

- O Paço Real o meu génio...

- E os dragões são o meu sangue...

(Se a minha alma fosse uma Princesa nua

E debochada e linda...)

7

Eu não sou eu nem sou o outro,

Sou qualquer coisa de intermédio:

Pilar da ponte de tédio

Que vai de mim para o Outro.

\section{APOTEOSE}

Mastros quebrados, singro num mar de Ouro

Dormindo fogo, incerto, longemente...

Tudo se me igualou num sonho rente,

E em metade de mim hoje só moro...

São tristezas de bronze as que inda choro Pilastras mortas, mármores ao Poente...

Lajearam-se-me as ânsias brancamente

Por claustros falsos onde nunca oro...

Desci de Mim. Dobrei o manto de Astro,

Quebrei a taça de cristal e espanto, 
Talhei em sombra o Oiro do meu rastro...

Findei... Horas-platina... Olor-brocado...

Luar-ânsia... Luz-perdão... Orquídeas-pranto...

- Ó pântanos de Mim - jardim estagnado!...

\begin{abstract}
ÂNGULO
Aonde irei neste sem-fim perdido,

Neste mar oco de certezas mortas? -

Fingidas, afinal, todas as portas

Que no dique julguei ter construído...

- Barcaças dos meus ímpetos tigrados,

Que oceano vos dormiram de Segredo?

Partiste-vos, transportes encantados,

De embate, em alma ao roxo, a que rochedo?

Ó nau de festa, ó ruiva de aventura

Onde, em Champanhe, a minha ânsia ia,

Quebraste-vos também ou, porventura,

Fundeaste a Oiro em portos de alquimia?...

Chegaram à baía os galeões

Com as sete Princesas que morreram.

Regatas de luar não se correram...

As bandeiras velaram-se, orações...

Detive-me na ponte, debruçado,

Mas a ponte era falsa - e derradeira.

Segui no cais. O cais era abaulado,

Cais fingido sem mar à sua beira...

- Por sobre o que Eu não sou há grandes pontes

Que um outro, só metade, quer passar

Em miragens de falsos horizontes -

Um outro que eu não posso acorrentar...
\end{abstract}

\title{
O PAJEM
}


Sozinho de brancura, eu vago - Asa

De rendas que entre cardos só flutua...

- Triste de Mim, que vim de Alma prà rua,

E nunca a poderei deixar em casa...

\section{Fernando Pessoa:}

\section{CHUVA OBLÍQUA}

Atravessa esta paysagem o meu sonho d'um porto infinito

E a côr das flôres é transparente de as velas de grandes navios

Que largam do caes arrastando nas aguas por sombra

Os vultos do sol d'aquellas arvores antigas...

O porto que sonho é sombrio e pallido

E esta paysagem é cheia de sol d'este lado...

Mas no meu espirito o sol d'este dia é porto sombrio

E os navios que sahem do porto são estas arvores ao sol...

Liberto em duplo, abandonei-me da paysagem abaixo...

$O$ vulto do caes é a estrada nitida e calma

Que se levanta e se ergue como um muro,

E os navios passam por dentro dos troncos das arvores

Com uma horizontalidade vertical,

E deixam cahir amarras na agua pelas folhas uma a uma dentro...

Não sei quem me sonho...

Súbito toda a agua do mar do porto é transparente

E vejo no fundo, como uma estampa enorme que lá estivesse desdobrada,

Esta paysagem toda, renque de arvores, estrada a arder em aquelle porto,

E a sombra d'uma náu mais antiga que o porto que passa

Entre o meu sonho do porto e o meu vêr esta paysagem

E chega ao pé de mim, e entra por mim dentro,

E passa para o outro lado da minha alma...

A Grande Esphynge do Egypto sonha por este papel dentro...

Escrevo - e ella apparece me atravez da minha mão transparente 
E ao canto do papel erguem-se as pyramides...

Escrevo - perturbo-me de vêr o bico da minha penna

Ser o perfil do rei Cheops...

De repente paro...

Escureceu tudo... Caio por um abysmo feito de tempo...

Estou soterrado sob as pyramides a escrever versos á luz clara d'este

[candieiro

E todo o Egypto me esmaga de alto atravez dos traços que faço com a

[penna...

Ouço a Esphynge rir por dentro

O som da minha penna a correr no papel...

Atravessa o eu não poder vel-a uma mão enorme,

Varre tudo para o canto do tecto que fica por detraz de mim,

E sobre o papel onde escrevo, entre elle e a penna que escreve

Jaz o cadaver do rei Cheops, olhando me com olhos muito abertos,

E entre os nossos olhares que se cruzam corre o Nilo

E uma alegria de barcos embandeirados erra

Numa diagonal diffusa

Entre mim e o que eu penso...

Funeraes do rei Cheops em ouro velho e Mim!...

\section{PASSOS DA CRUZ}

\section{VI}

Venho de longe e trago no perfil, Em forma nevoenta e afastada, $O$ perfil de outro ser que desagrada Ao meu actual recorte humano e vil.

Outrora fui talvez, não Boabdil, Mas o seu mero último olhar, da estrada Dado ao deixado vulto de Granada, Recorte frio sob o unido anil...

Hoje sou a saudade imperial Do que já na distância de mim vi... Eu próprio sou aquilo que perdi...

E nesta estrada para Desigual Florem em esguia glória marginal Os girassóis do império que morri... 
Não sou eu quem descrevo. Eu sou a tela E oculta mão colora alguém em mim.

Pus a alma no nexo de perde-la

E o meu princípio floresceu em Fim.

Que importa o tédio que dentro em mim gela, E o leve Outono, e as galas, e o marfim, $\mathrm{E}$ a congruência da alma que se vela Com os sonhados pálios de cetim?

Disperso... E a hora como um leque fecha-se... Minha alma é um arco tendo ao fundo o mar... O tédio? A mágoa? A vida? O sonho? Deixa-se...

E, abrindo as asas sobre Renovar, A erma sombra do voo começado Pestaneja no campo abandonado...

\section{XIII}

Emissário de um rei desconhecido

Eu cumpro informes instruções de além,

$\mathrm{E}$ as bruscas frases que aos meus lábios vêm

Soam-me a um outro e anómalo sentido...

Inconscientemente me divido

Entre mim e a missão que o meu ser tem, E a glória do meu Rei dá-me o desdém

Por este humano povo entre quem lido...

Não sei se existe o Rei que me mandou.

Minha missão será eu a esquecer,

Meu orgulho o deserto em que em mim estou...

Mas há! Eu sinto-me altas tradições

De antes de tempo e espaço e vida e ser...

Já viram Deus as minhas sensações...

EPISÓDIOS

(A Múmia) 
Andei léguas de sombra

Dentro em meu pensamento.

Floresceu às avessas

Meu ócio com sem-nexo,

E apagaram-me as lâmpadas

$\mathrm{Na}$ alcova cambaleante.

Tudo prestes se volve

Um deserto macio

Visto pelo meu tacto

Dos veludos da alcova,

Não pela minha vista,

Há um oásis no Incerto

E, como uma suspeita

De luz por não-há-frinchas,

Passa uma caravana.

Esquece-me de súbito

Como é o espaço, e o tempo

Em vez de horizontal

É vertical.

\section{A alcova}

Desce não sei por onde

Até não me encontrar.

Ascende um leve fumo

Das minhas sensações.

Deixo de me incluir

Dentro de mim. Não há

Cá-dentro nem lá-fora.

E o deserto está agora

Virado para baixo.

A noção de mover-me

Esqueceu-se do meu nome.

$\mathrm{Na}$ alma meu corpo pesa-me.

Sinto-me um reposteiro

Pendurado na sala

Onde jaz alguém morto.

Qualquer coisa caiu

E tiniu no infinito. 
De quem é o olhar

Que espreita por meus olhos?

Quando penso que vejo,

Quem continua vendo

Enquanto estou pensando?

Por que caminhos seguem,

Não os meus tristes passos,

Mas a realidade

De eu ter passos comigo?

Às vezes, na penumbra

Do meu quarto, quando eu

Para mim próprio mesmo

Em alma mal existo,

Toma um outro sentido

Em mim o Universo -

É uma nódoa esbatida

De eu ser consciente sobre

Minha idéia das coisas.

Se acenderem as velas

E não houver apenas

A vaga luz de fora -

Não sei que candeeiro

Aceso onde na rua -

Terei foscos desejos

De nunca haver mais nada

No Universo e na Vida

De que o obscuro momento

Que é minha vida agora

Um momento afluente

Dum rio sempre a ir

Esquecer-se de ser,

Espaço misterioso

Entre espaços desertos

Cujo sentido é nulo

E sem ser nada a nada.

E assim a hora passa

Metafisicamente.

Súbita mão de algum fantasma oculto

Entre as dobras da noite e do meu sono

Sacode-me e eu acordo, e no abandono

Da noite não enxergo gesto ou vulto. 
Mas um terror antigo, que insepulto

Trago no coração, como de um trono

Desce e se afirma meu senhor e dono

Sem ordem, sem meneio e sem insulto.

E eu sinto a minha vida de repente

Presa por uma corda de Inconsciente

A qualquer mão nocturna que me guia.

Sinto que sou ninguém salvo uma sombra

De um vulto que não vejo e que assombra,

E em nada existo como a treva fria.

No entardecer da terra

O sopro do longo Outono

Amareleceu no chão.

Um vago vento erra,

Como um sonho mau num sono,

Na lívida solidão.

Soergue as folhas, e pousa

As folhas, e volve, e revolve,

E esvai-se inda outra vez.

Mas a folha não repousa,

E o vento lívido volve

E expira na lividez.

Eu já não sou quem era;

O que eu sonhei, morri-o;

E até do que hoje sou

Amanhã direi, quem dera

Volver a sê-lo!... Mais frio

$\mathrm{O}$ vento vago voltou.

Gato que brincas na rua

Como se fosse na cama,

Invejo a sorte que é tua

Porque nem sorte se chama.

Bom servo das leis fatais

Que regem pedras e gentes,

Que tens instintos gerais

E sentes só o que sentes.

És feliz porque és assim, 
Todo o nada que és é teu.

Eu vejo-me e estou sem mim,

Conheço-me e não sou eu.

Hoje que a tarde é calma e o céu tranqüilo, E a noite chega sem que eu saiba bem, Quero considerar-me a ver aquilo Que sou, e o que sou o que é que tem.

Olho por todo o meu passado e vejo Que fui quem foi aquilo em torno meu, Salvo o que o vago e incógnito desejo De ser eu mesmo de meu ser me deu.

Como a páginas já relidas, vergo Minha atenção sobre quem fui de mim, E nada de verdade em mim albergo Salvo uma ânsia sem princípio ou fim.

Como alguém distraído na viagem, Segui por dois caminhos par em par. Fui com o mundo, parte da paisagem; Comigo fui, sem ver nem recordar.

Chegado aqui, onde hoje estou, conheço Que sou diverso no que informe estou. No meu próprio caminho me atravesso. Não conheço quem fui no que hoje sou.

Serei eu, porque nada é impossível, Vários trazidos de outros mundos, e No mesmo ponto espacial sensível Que sou eu, sendo eu por 'star aqui?

Serei eu, porque todo o pensamento Podendo conceber, bem pode ser, Um dilatado e múrmuro momento, De tempos-seres de quem sou o viver?

Não meu, não meu é quanto escrevo, A quem o devo?

De quem sou o arauto nado?

Porque, enganado, Julguei ser meu o que era meu?

Que outro mo deu? 
Mas, seja como for, se a sorte

For eu ser morte

De uma outra vida que em mim vive,

$\mathrm{Eu}$, o que estive

Em ilusão toda esta vida

Aparecida,

Ou grato Ao que do pó que sou

Me levantou.

(E me fez nuvem um momento

De pensamento).

(Ao de quem sou, erguido pó, Símbolo só).

Porque é que um sono agita

Em vez de repousar

O que em minha alma habita

$\mathrm{E}$ a faz não descansar?

Que externa sonolência,

Que absurda confusão,

Mas oprime sem violência,

Me faz ver sem visão?

Entre o que vivo e a vida,

Entre quem estou e sou,

Durmo numa descida,

Descida em que não vou.

E, num fiel regresso

Ao que já era bruma,

Sonolento me apresso

Para coisa nenhuma.

Entre o sono e o sonho,

Entre mim e o que em mim

É o quem eu me suponho,

Corre um rio sem fim.

Passou por outras margens,

Diversas mais além,

Naquelas várias viagens

Que todo o rio tem.

Chegou onde hoje habito

A casa que hoje sou. 
Passa, se eu me medito;

Se desperto, passou.

E quem me sinto e morre

No que me liga a mim

Dorme onde o rio corre -

Esse rio sem fim.

Repousa sobre o trigo

Que ondula um sol parado.

Não me entendo comigo.

Ando sempre enganado.

Tivesse eu conseguido

Nunca saber de mim,

Ter-me-ia esquecido

De ser esquecido assim.

O trigo mexe leve

Ao sol alheio e igual.

Como a alma aqui é breve

Com o seu bem e mal!

Tudo que faço ou medito

Fica sempre na metade.

Querendo, quero o infinito.

Fazendo, nada é verdade.

Que nojo de mim me fica

Ao olhar para o que faço!

Minha alma é lúcida e rica,

E eu sou um mar de sargaço -

Um mar onde bóiam lentos

Fragmentos de um mar de além...

Vontades ou pensamentos?

Não o sei e sei-o bem.

Tenho tanto sentimento

Que é frequente persuadir-me

De que sou sentimental,

Mas reconheço, ao medir-me,

Que tudo isso é pensamento, 
Que não senti afinal.

Temos, todos que vivemos, Uma vida que é vivida

E outra vida que é pensada,

E a única vida que temos

É essa que é dividida

Entre a verdadeira e a errada.

Qual porém é verdadeira

E qual errada, ninguém

Nos saberá explicar;

$E$ vivemos de maneira

Que a vida que a gente tem

É a que tem que pensar.

No mal-estar em que vivo, No mal pensar em que sinto, Sou de mim mesmo cativo, A mim mesmo minto.

Se fosse outro fora outro.

Se em mim houvesse certeza, Não seria o fluido e neutro Que ama a beleza.

Sim, que ama a beleza e a nega Nesta vida sem bordão

Que contra si mesma alega Que tudo é vão.

Houve um ritmo do meu sono. Quando acordei o perdi.

Porque saí do abandono

De mim mesmo, em que vivi?

Não sei que era o que não era.

Sei que suave me embalou, Como se o embalar quisera

Tornar-me outra vez quem sou.

Houve uma música finda Quando acordei de a sonhar. Mas não morreu: dura ainda

No que me faz não pensar. 


\section{AUTOPSICOGRAFIA}

O poeta é um fingidor.

Finge tão completamente

Que chega a fingir que é dor A dor que deveras sente.

E os que lêem o que escreve, $\mathrm{Na}$ dor lida sentem bem,

Não as duas que ele teve,

Mas só a que eles não têm.

E assim nas calhas de roda

Gira, a entreter a razão,

Esse comboio de corda

Que se chama coração.

\section{ISTO}

Dizem que finjo ou minto

Tudo que escrevo. Não.

Eu simplesmente sinto

Com a imaginação.

Não uso o coração.

Tudo o que sonho ou passo, $\mathrm{O}$ que me falha ou finda, É como que um terraço

Sobre outra coisa ainda.

Essa coisa é que é linda.

Por isso escrevo em meio

Do que não está ao pé,

Livre do meu enleio,

Sério do que não é.

Sentir? Sinta quem lê!

Parece às vezes que desperto

E me pergunto o que vivi;

Fui claro, fui real, é certo,

Mas como é que cheguei aqui? 
A bebedeira às vezes dá

Uma assombrosa lucidez

Em que como outro a gente está.

Estive ébrio sem beber talvez.

E de aí, se pensar, o mundo

Não será feito só de gente

No fundo cheia de este fundo

De existir clara e èbriamente?

Entendo, como um carrossel,

Giro em meu torno sem me achar...

(Vou escrever isto num papel

Para ninguém me acreditar...)

Cheguei à janela,

Porque ouvi cantar.

É um cego e a guitarra

Que estão a chorar.

Ambos fazem pena,

São uma coisa só

Que anda pelo mundo

A fazer ter dó.

Eu também sou um cego

Cantando na estrada,

A estrada é maior

E não peço nada.

O mau aroma alacre

Da maresia

Sobe no esplendor acre

Do dia.

Falsa, a ribeira é lodo

Ainda a aguar.

Olho, e o que sou está todo

A não olhar.

E um mal de mim a deixa.

Tenho lodo em mim -

Ribeira que se queixa

De o rio ser assim. 
Vão breves passando

Os dias que tenho.

Depois de passarem

Já não os apanho.

De aqui a tão pouco

Ainda acabou.

Vou ser um cadáver

Por quem se rezou.

E entre hoje e esse dia

Farei o que fiz:

Ser qual quero eu ser,

Feliz ou infeliz.

Fito-me frente a frente

E conheço quem sou.

Estou louco, é evidente,

Mas que louco é que estou?

É por ser mais poeta

Que gente que sou louco?

Ou é por ter completa

A noção de ser pouco?

Não sei, mas sinto morto

O ser vivo que tenho.

Nasci como um aborto,

Salvo a hora e o tamanho.

Sou um evadido.

Logo que nasci

Fecharam-me em mim,

$\mathrm{Ah}$, mas eu fugi.

Se a gente se cansa

Do mesmo lugar,

Do mesmo ser

Por que não se cansar?

Minha alma procura-me

Mas eu ando a monte,

Oxalá que ela 
Nunca me encontre.

Ser um é cadeia,

Ser eu é não ser.

Viverei fugindo

Mas vivo a valer.

Bem, hoje que estou só e posso ver

Com o poder de ver do coração

Quanto não sou, quanto não posso ser,

Quanto, se o for, serei em vão,

Hoje, vou confessar, quero sentir-me

Definitivamente ser ninguém,

E de mim mesmo, altivo, demitir-me

Por não ter procedido bem.

Falhei a tudo, mas sem galhardias,

Nada fui, nada ousei e nada fiz,

Nem colhi nas ortigas dos meus dias

A flor de parecer feliz.

Mas fica sempre, porque o pobre é rico

Em qualquer cousa, se procurar bem,

A grande indiferença com que fico.

Escrevo-o para o lembrar bem.

No céu da noite que começa

Nuvens de um vago negro brando

Numa ramagem pouco espessa

Vão no ocidente tresmalhando.

Aos sonhos que não sei me entrego

Sem nada procurar sentir

E estou em mim como em sossego,

Pra sono falta-me dormir.

Deixei atrás nas horas ralas

Caídas uma outra ilusão,

Não volto atrás a procurá-las,

Já estão formigas onde estão.

Chove. Que fiz eu da vida? 
Fiz o que ela fez de mim...

De pensada, mal vivida...

Triste de quem é assim!

Numa angústia sem remédio

Tenho febre na alma, e, ao ser,

Tenho saudade, entre o tédio,

Só do que nunca quis ter...

Quem eu pudera ter sido,

Que é dele? Entre ódios pequenos

De mim, stou de mim partido.

Se ao menos chovesse menos!

Em outro mundo, onde a vontade é lei,

Livremente escolhi aquela vida

Com que primeiro neste mundo entrei.

Livre, a ela fiquei preso e eu a paguei

Com o preço das vidas subsequentes

De que ela é a causa, o deus; e esses entes,

Por ser quem fui, serão o que serei.

Porque pesa em meu corpo e minha mente

Esta miséria de sofrer? Não foi

Minha a culpa e a razão do que me dói.

Não tenho hoje memória, neste sonho

Que sou de mim, de quanto quis ser eu.

Nada de nada surge do medonho

Abismo de quem sou em Deus, do meu

Ser anterior a mim, a me dizer

Quem sou, esse que fui quando no céu,

Ou o que chamam céu, pude querer.

Sou entre mim e mim o intervalo -

$\mathrm{Eu}$, o que uso esta forma definida

De onde para outra ulterior resvalo.

Em outro mundo

[..]

Porque esqueci quem fui quando criança?

Porque deslembra quem então era eu?

Porque não há nenhuma semelhança

Entre quem sou e fui?

A criança que fui vive ou morreu?

Sou outro? Veio um outro em mim viver? 
A vida, que em mim flui, em que é que flui?

Houve em mim várias almas sucessivas

Ou sou um só inconsciente ser?

Nesta vida, em que sou meu sono,

Não sou meu dono,

Quem sou é quem me ignoro e vive

Através desta névoa que sou eu

Todas as vidas que eu outrora tive,

Numa só vida.

Mar sou; baixo marulho ao alto rujo,

Mas minha cor vem do meu alto céu,

E só me encontro quando de mim fujo.

Quem quando eu era infante me guiava

Senão a vera alma que em mim estava?

Atada pelos braços corporais,

Não podia ser mais.

Mas, certo, um gesto, olhar ou esquecimento

Também, aos olhos de quem bem olhou,

A Presença Real sob o disfarce

Da minha alma presente sem intento.

Sabes quem sou? Eu não sei.

Outrora, onde o nada foi,

Fui o vassalo e o rei.

É dupla a dor que me dói.

Duas dores eu passei.

Fui tudo que pode haver.

Ninguém me quis esmolar;

E entre o pensar e o ser

Senti a vida passar

Como um rio sem correr.

Criança, era outro...

Naquele em que me tornei

Cresci e esqueci.

Tenho de meu, agora, um silêncio, uma lei.

Ganhei ou perdi? 
Longe de mim em mim existo

Àparte de quem sou,

A sombra e o movimento em que consisto.

Cansado até dos deuses que não são...

Ideais, sonhos... Como o sol é real

E na objectiva coisa universal

Não há o meu coração...

Eu ergo a mão.

Olho-a de mim, e o que ela é não sou eu.

Entre mim e o que sou há a escuridão.

Mas o que são a isto a terra e o céu?

Houvesse ao menos, visto que a verdade

É falsa, qualquer coisa verdadeira

De outra maneira

Que a impossível certeza ou realidade.

Houvesse ao menos, sob o sol do mundo, Qualquer postiça realidade não

O eterno abismo sem fundo,

Crível talvez, mas tendo coração.

Mas não há nada, salvo tudo sem mim.

Crível por fora da razão, mas sem

Que a razão acordasse e visse bem;

Real com coração, inda que [...]

Qualquer caminho leva a toda a parte,

Qualquer caminho

Em qualquer ponto seu em dois se parte

E um leva a onde indica a strada

Outro é sòzinho.

Um leva ao fim da mera strada, pára

Onde acabou.

Outro é a abstracta margem

No inútil desfilar de sensações

Chamado a vida,

No cambalear coerente de visões

Do $[\ldots]$ 
Ah! os caminhos stão todos em mim. Qualquer distância ou direcção, ou fim Pertence-me, sou eu. O resto é a parte De mim que chamo o mundo exterior. Mas o caminho deus eis se biparte Em o que eu sou e o alheio a mim $[\ldots]$

É uma brisa leve

Que o ar um momento teve

E que passa sem ter

Quase por tudo ser.

Quem amo não existe.

Vivo indeciso e triste.

Quem quis ser já me esquece

Quem sou não me conhece.

E em meio disto o aroma Que a brisa traz me assoma Um momento à consciência Como uma confidência.

Aqui neste profundo apartamento Em que, não por lugar, mas mente estou, No claustro de ser eu, neste momento Em que me encontro e sinto-me o que vou,

Aqui, agora, rememoro

Quanto de mim deixei de ser E inùtilmente, [...] choro

$\mathrm{O}$ que sou e não pude ter.

Durmo. Regresso ou espero?

Não sei. Um outro flui

Entre o que sou e o que quero

Entre o que sou e o que fui.

Velo, na noite em mim, Meu próprio corpo morto. Velo, inútil absorto. 
Ele tem o seu fim

Inùtilmente, enfim.

Brincava a criança

Com um carro de bois.

Sentiu-se brincando

E disse, eu sou dois!

Há um brincar

E há outro a saber,

Um vê-me a brincar

E outro vê-me a ver.

Estou por trás de mim

Mas se volto a cabeça

Não era o que eu qu'ria

A volta só é essa...

O outro menino

Não tem pés nem mãos

Nem é pequenino

Não tem mãe ou irmãos.

E havia comigo

Por trás de onde eu estou, Mas se volto a cabeça

Já não sei o que sou.

E o tal que eu cá tenho

E sente comigo,

Nem pai, nem padrinho,

Nem corpo ou amigo,

Tem alma cá dentro

Stá a ver-me sem ver,

E o carro de bois

Começa a parecer.

Mas o hóspede inconvidado

Que mora no meu destino,

Que não sei como é chegado,

Nem de que honras é dino.

Constrange meu ser de casa

A adaptações de disfarce. 
Mas eu, alheio sempre, sempre entrando

O mais íntimo ser da minha vida,

Vou dentro em mim a sombra procurando.

Relógio, morre -

Momentos vão...

Nada já ocorre

Ao coração

Senão, senão...

Bem que perdi,

Mal que deixei,

Nada aqui

Montes sem lei

Onde estarei...

Ninguém comigo!

Desejo ou tenho?

Sou o inimigo -

De onde é que venho?

O que é que estranho?

Mais triste do que o que acontece

É o que nunca aconteceu.

Meu coração, quem o entristece?

Quem o faz meu?

Na núvem vem o que escurece

O grande campo sob o céu.

Memórias? Tudo é o que esquece.

A vida é quanto se perdeu.

E há gente que não enlouquece!

Ai do que em mim me chamo eu!

Depois que todos foram

E foi também o dia,

Ficaram entre as sombras

Das áleas do ermo parque

Eu e a minha agonia. 
A festa fora alheia

E depois que acabou

Ficaram entre as sombras

Das áleas apertadas

Quem eu fui e quem sou.

Tudo fora por todos.

Brincaram, mas enfim

Ficaram entre as sombras

Das áleas apertadas

Só eu, e eu sem mim.

Talvez que no parque antigo

A festa volte a ser.

Ficaram entre as sombras

Das áleas apertadas

Eu e quem sei não ser.

Meus versos são meu sonho dado.

Quero viver, não sei viver,

Por isso, anónimo e encantado,

Canto para me pertencer.

O que salvamos, o perdemos.

O que pensamos, já o fomos.

Ah, e só guardamos o que demos

E tudo é sermos quem não somos.

Se alguém sabe sentir meu canto

Meu canto eu saberei sentir.

Viverei com minha alma tanto

Tanto quanto antes vivi.

Gostara, realmente,

De sentir com uma alma só,

Não ser eu só gente

De muitos, mete-me dó.

Não ter lar, vá. Não ter calma

Stá bem, nem ter pertencer.

Mas eu, de ter tanta alma,

Nem minha alma chego a ter. 
Deus não tem unidade, Como a terei eu?

Deixo ao cego e ao surdo A alma com fronteiras, Que eu quero sentir tudo De todas as maneiras.

Do alto de ter consciência Contemplo a terra e o céu, Olho-os com inocência:

Nada que vejo é meu.

Mas vejo tão atento

Tão neles me disperso

Que cada pensamento

Me torna já diverso.

E como são estilhaços Do ser, as coisas dispersas Quebro a alma em pedaços E em pessoas diversas.

E se a própria alma vejo Com outro olhar, Pergunto se há ensejo De por isto a julgar.

Ah, tanto como a terra E o mar e o vasto céu. Quem se crê próprio erra, Sou vário e não sou meu.

Se as coisas são estilhaços Do saber do universo, Seja eu os meus pedaços, Impreciso e diverso.

Se quanto sinto é alheio E de mim se sente, Como é que a alma veio A acabar-se em ente?

Assim eu me acomodo Com o que Deus criou, Deixo teu diverso modo Diversos modos sou. 
Assim a Deus imito,

Que quando fez o que é

Tirou-lhe o infinito

$\mathrm{E}$ a unidade até.

Quero ser livre insincero

Sem crença, dever ou posto.

Prisões, nem de amor as quero.

Não me amem, porque não gosto.

Quando canto o que não minto

E choro o que sucedeu,

É que esqueci o que sinto

E julgo que não sou eu.

De mim mesmo viandante

Olho as músicas na aragem,

E a minha mesma alma errante

É uma canção de viagem.

$\mathrm{O}$ rio que passa dura

Nas ondas que há em passar,

E cada onda figura

$\mathrm{O}$ instante de um lugar.

Pode ser que o rio siga,

Mas a onda que passou

É outra quando prossiga.

Não continua: durou.

Qual é o ser que subsiste

Sob estas formas de estar,

A onda que não existe,

O rio que é só passar?

Não sei, e o meu pensamento

Também não sabe se é,

Como a onda o seu momento

Como o rio [?] 
Eis-me em mim absorto

Sem o conhecer

Bóio no mar morto

Do meu próprio ser.

Sinto-me pesar

No meu sentir-me água...

Eis-me a balancear

Minha vida-mágoa.

Barco sem ter velas...

De quilha virada...

O céu com estrelas

É frio como espada.

E eu sou vento e céu...

Sou o barco e o mar...

Só que não sou eu...

Quero-o ignorar.

\section{DEUS}

Às vezes sou o Deus que trago em mim E então eu sou o Deus e o crente e a prece $E$ a imagem de marfim

Em que esse deus se esquece.

Às vezes não sou mais do que um ateu

Desse deus meu que eu sou quando me exalto.

Olho em mim todo um céu

E é um mero oco céu alto.

Sou o fantasma de um rei Que sem cessar percorre As salas de um palácio abandonado...

Minha história não sei...

Longe em mim, fumo de eu pensá-la, morre

A ideia de que tive algum passado...

Eu não sei o que sou. 
Não sei se sou o sonho

Que alguém do outro mundo esteja tendo...

Creio talvez que estou

Sendo um perfil casual de rei tristonho

Numa história que um deus está relendo...

10-2-1917

O mundo rui a meu redor, escombro a escombro.

Os meus sentidos oscilam, bandeira rota ao vento.

Que sombra de que o sol enche de frio e de assombro

A estrada vazia do conseguimento?

Busca um porto longe uma nau desconhecida

E esse é todo o sentido da minha vida.

Por um mar azul nocturno, estrelado no fundo, Segue a sua rota a nau exterior ao mundo.

Mas o sentido de tudo está fechado no pasmo

Que exala a chama negra que acende em meu entusiasmo

Súbitas confissões de outro que eu fui outrora

Antes da vida e viu Deus e eu não o sou agora.

$7-7-1930$

Dormi. Sonhei. No informe labirinto

Que há entre a vida e a morte me perdi.

E o que, na vaga viagem, eu senti

Com exacta memória não o sinto.

Se quero achar-me em mim dizendo-o, minto.

A vasta teia, estive-a e não a vi.

Obscuramente me desconcebi.

Não sei quantas almas tenho.

Cada momento mudei.

Continuamente me estranho.

Nunca me vi nem achei.

De tanto ser, só tenho alma. 
Quem tem alma não tem calma.

Quem vê é só o que vê,

Quem sente não é quem é,

Atento ao que sou e vejo,

Torno-me eles e não eu.

Cada meu sonho ou desejo

É do que nasce e não meu.

Sou minha própria paisagem,

Assisto à minha passagem,

Diverso, móbil e só,

Não sei sentir-me onde estou.

Por isso, alheio, vou lendo

Como páginas, meu ser.

O que segue não prevendo,

$\mathrm{O}$ que passou a esquecer.

Noto à margem do que $\mathrm{li}$

$\mathrm{O}$ que julguei que senti.

Releio e digo: "Fui eu?"

Deus sabe, porque o escreveu.

Tenho pena e não respondo.

Mas não tenho culpa enfim

De que em mim não correspondo

Ao outro que amaste em mim.

Cada um é muita gente.

Para mim sou quem me penso,

Para outros - cada um sente

O que julga, e é um erro imenso.

Ah, deixem-me sossegar.

Não me sonhem nem me outrem.

Se eu não me quero encontrar,

Quererei que outros me encontrem?

22-9-1933

I

A criança que fui chora na estrada.

Deixei-a ali quando vim ser quem sou; 
Mas hoje, vendo que o que sou é nada, Quero ir buscar quem fui onde ficou.

Ah, como hei-de encontra-lo? Quem errou $A$ vinda tem a regressão errada.

Já não sei de onde vim nem onde estou.

De o não saber, minha alma está parada.

Se ao menos atingir neste lugar

Um alto monte, de onde possa enfim

O que esqueci, olhando-o, relembrar,

$\mathrm{Na}$ ausência, ao menos, saberei de mim, $\mathrm{E}$, ao ver-me tal qual fui ao longe, achar

Em mim um pouco de quando era assim.

II

Dia a dia mudamos para quem

Amanhã não veremos. Hora a hora

Nosso diverso e sucessivo alguém

Desce uma vasta escadaria agora.

É uma multidão que desce, sem

Que um saiba de outros. Vejo-os meus e fora.

Ah, que horrorosa semelhança têm!

São um múltiplo mesmo que se ignora.

Olho-os. Nenhum sou eu, a todos sendo.

E a multidão engrossa, alheia a ver-me,

Sem que eu perceba de onde vai crescendo.

Sinto-os a todos dentro em mim mover-me, $\mathrm{E}$, inúmero, prolixo, vou descendo

Até passar por todos e perder-me.

(dream)

Qualquer coisa de obscuro permanece

No centro do meu ser. Se me conheço,

É até onde, por fim mal, tropeço

No que de mim em mim de si se esquece. 
Aranha absurda que uma teia tece Feita de solidão e de começo

Fruste, meu ser anónimo confesso

Próprio e em mim mesmo a externa treva desce.

Mas, vinda dos vestígios da distância

Ninguém trouxe ao meu pálio por ter gente

Sob ele, um rasgo de saudade ou ânsia.

Remiu-se o pecador impenitente

À sombra e cisma. Teve a eterna infância, Em que comigo forma um mesmo ente.

Durmo ou não? Passam juntas em minha alma Coisas da alma e da vida em confusão, Nesta mistura atribulada e calma Em que não sei se durmo ou não.

Sou dois seres e duas consciências Como dois homens indo braço-dado. Sonolento revolvo omnisciências, Turbulentamente estagnado.

Mas, lento, vago, emerjo de meu dois.

Disperto. Enfim: sou um, na realidade.

Espreguiço-me. Estou bem... Porquê depois, De quê, esta vaga saudade?

Divido o que conheço.

De um lado é o que sou

Do outro quanto esqueço.

Por entre os dois eu vou.

Não sou nem quem me lembro

Nem sou quem há em mim.

Se penso me desmembro.

Se creio, não há fim.

Que melhor que isto tudo

É ouvir, na ramagem

Aquele ar certo e mudo 
Que estremece a folhagem.

Deslembro incertamente. Meu passado

Não sei quem o viveu. Se eu mesmo fui,

Está confusamente deslembrado

E logo em mim enclausurado flui.

Não sei quem fui nem sou. Ignoro tudo.

Só há de meu o que me vê agora -

O campo verde, natural e mudo

Que um vento que não vejo vago aflora.

Sou tão parado em mim que nem o sinto.

Vejo, e onde [o] vale se ergue para a encosta

Vai meu olhar seguindo o meu instinto

Como quem olha a mesa que está posta.

Bem sei que estou endoidecendo.

Bem sei que falha em mim quem sou.

Sim, mas, enquanto me não rendo,

Quero saber por onde vou.

Inda que vá para render-me

Ao que o Destino me faz ser,

Quero, um momento, aqui deter-me

E descansar a conhecer.

Há grandes lapsos de memória

Grandes paralelas perdidas,

E muita lenda e muita história

E muitas vidas, muitas vidas.

Tudo isso; agora me perco

De mim e vou a transviar,

Quero chamar a mim, e cerco

Meu ser de tudo relembrar.

Porque, se vou ser louco, quero

Ser louco com moral e siso.

Vou tanger lira como Nero.

Mas o incêndio não é preciso. 
s. d.

Meu pensamento, dito, já não é

Meu pensamento.

Flor morta, bóia no meu sonho, até

Que a leve o vento,

Que a desvie a corrente, a externa sorte.

Se falo, sinto

Que a palavras esculpo a minha morte,

Que com toda a alma minto.

Assim, quanto mais digo, mais me engano,

Mais faço eu

Um novo ser postiço, que engalano

De ser o meu.

Já só pensando escuto-me e resido.

Já falo assim.

Meu próprio diálogo interior divide

Meu ser de mim.

Mas é quando dou forma e voz do 'spaço

Ao que medito

Que abro entre mim e mim, quebrado um laço,

Um abismo infinito.

Ah, quem dera a perfeita concordância

De mim comigo,

O silêncio interior sem a distância

Entre mim e o que eu digo!

s. d.

Lembro-me bem do seu olhar.

Ele atravessa ainda a minha alma,

Como um risco de fogo na noite.

Lembro-me bem do seu olhar. O resto...

Sim o resto parece-se apenas com a vida.

Ontem, passei nas ruas como qualquer pessoa.

Olhei para as montras despreocupadamente

E não encontrei amigos com quem falar.

De repente vi que estava triste, mortalmente triste,

Tão triste que me pareceu que me seria impossível

Viver amanhã, não porque morresse ou me matasse, 
Mas porque seria impossível viver amanhã e mais nada.

Fumo, sonho, recostado na poltrona.

Dói-me viver como uma posição incómoda.

Deve haver ilhas lá para o sul das cousas

Onde sofrer seja uma cousa mais suave,

Onde viver custe menos ao pensamento,

E onde a gente possa fechar os olhos e adormecer ao sol

E acordar sem ter que pensar em responsabilidades sociais

Nem no dia do mês ou da semana que é hoje.

Abrigo no peito, como a um inimigo que temo ofender,

Um coração exageradamente espontâneo

Que sente tudo o que eu sonho como se fosse real,

Que bate com o pé a melodia das canções que o meu pensamento

[canta,

Canções tristes, como as ruas estreitas quando chove.

\section{Alexandre O’Neill:}

comigo me desavim

eu não sou eu nem sou o outro

sou posto em todo perigo

sou qualquer coisa de intermédio

não posso viver comigo

pilar na ponte de tédio

não posso viver sem mim

que vai de mim para o Outro

\section{Maria Teresa Horta:}

Minha senhora de mim

Comigo me desavim

minha senhora

de mim

sem ser dor ou ser cansaço 
nem o corpo que disfarço

Comigo me desavim minha senhora

de mim

nunca dizendo comigo

o amigo nos meus braços

Comigo me desavim minha senhora

de mim

recusando o que é desfeito no interior do meu peito 